Florida International University FIU Digital Commons

6-18-2010

\title{
Politics at the Water's Edge: The Presidency, Congress, and the North Korea Policy of the United States
}

Taehyung Ahn

Florida International University, taehyungahn@hotmail.com

DOI: $10.25148 /$ etd.FI10081211

Follow this and additional works at: https://digitalcommons.fiu.edu/etd

Part of the International Relations Commons

\section{Recommended Citation}

Ahn, Taehyung, "Politics at the Water's Edge: The Presidency, Congress, and the North Korea Policy of the United States" (2010). FIU Electronic Theses and Dissertations. 252.

https://digitalcommons.fiu.edu/etd/252

This work is brought to you for free and open access by the University Graduate School at FIU Digital Commons. It has been accepted for inclusion in FIU Electronic Theses and Dissertations by an authorized administrator of FIU Digital Commons. For more information, please contact dcc@fiu.edu. 


\title{
FLORIDA INTERNATIONAL UNIVERSITY
}

Miami, Florida

POLITICS AT THE WATER'S EDGE:

THE PRESIDENCY, CONGRESS, AND THE NORTH KOREA POLICY

OF THE UNITED STATES

\author{
A dissertation submitted in partial fulfillment of the \\ requirements for the degree of \\ DOCTOR OF PHILOSOPHY \\ in \\ INTERNATIONAL RELATIONS \\ by
}

Taehyung Ahn

2010 
To: Dean Kenneth Furton

College of Arts and Sciences

This dissertation, written by Taehyung Ahn, and entitled Politics at the Water's Edge: The Presidency, Congress, and the North Korea Policy of the United States, having been approved in respect to style and intellectual content, is referred to you for judgment.

We have read this dissertation and recommend that it be approved.

Nicholas G. Onuf

Mohiaddin Mesbahi

Steven Heine

Paul A. Kowert, Major Professor

Date of Defense: June 18, 2010

The dissertation of Taehyung Ahn is approved.

Dean Kenneth Furton
College of Arts and Sciences

Interim Dean Kevin O'Shea

University Graduate School

Florida International University, 2010 
C Copyright 2010 by Taehyung Ahn

All rights reserved. 


\section{DEDICATION}

I dedicate this dissertation to my mother. Without her patience, understanding, support, and most of all love, the completion of this work would not have been possible. 


\section{ACKNOWLEDGMENTS}

This dissertation would not have been possible without the support and help from my family, teachers, and friends. I wish to thank the members of my committee: Dr. Nicholas Onuf, Dr. Mohiaddin Mesbahi, Dr. Steven Heine for their support, patience, and guidance. Finally, I would like to thank my major professor, Dr. Paul Kowert, for his going the extra mile in sparing no pains for my work.

I also wish to thank the faculty members and the staff members of Department of Politics and International Relations: Dr. John Clark, Dr. Francois Debrix, Dr. Roderick Neumann, Dr. Elizabeth Prugl, Dr. Thomas Breslin, and Dr. Sarah Poggione, Michelle Real, Martha Rodriguez, Luz Aviles, Teresa Grullon, Lany Munoz, Kathy Hasselbach, and Mary Cossio.

Additionally, I wish to thank my friends: Dr. Harry Gould, Dr. Majid Al-Khalili, Dr. Bongman Seo, Mita Saksena, Steve Amrol, Hamid Serri, Yukari Ito, Jungtaek Seo, Jihyun Jeon, Sanghoon Han, Hansin Kim, Sunghyuk Moon, Dr. Hoieun Kim, Dr. Yongwook Lee, Dr. Jongkun Choi, Jen, Sal, Changsuk Oh, Seunghoi Kim, Dr. Inkwon Bang, Dr. Kyungnam Han, Dr. Sangki Lee, Dr. Leung Kim, Dr. Maree Lee, Dr. Chanho Chae, Jintae Kim, Seungwoo Je, Myongkon Kim, Youna Jung, and Jonghee Park.

Finally, I wish to thank my family: my mother, Jaehyung, Eunyoung, Woosung, Joohyung, Youngjoo, Dohyun, Myongja Lee, Wonjoon Lee, and my forever love Annie. 


\author{
ABSTRACT OF THE DISSERTATION \\ POLITICS AT THE WATER'S EDGE: \\ THE PRESIDENCY, CONGRESS, AND THE NORTH KOREA POLICY \\ OF THE UNITED STATES
}

by

Taehyung Ahn

Florida International University, 2010

Miami, Florida

Professor Paul A. Kowert, Major Professor

For all their efforts to avoid a nuclear North Korea, the Clinton and Bush administrations failed to achieve this goal, the most important policy objective of the United States in its relations with North Korea for decades, mainly because of inconsistencies in U.S. policy. This dissertation seeks to explain why both administrations ultimately failed to prevent North Korea from going nuclear. It finds the origins of this failure in the implementation of different U.S. policy options toward North Korea during the Clinton and Bush administrations.

To explain the lack of policy consistency, the dissertation investigates how the relations between the executive and the legislative branches and, more specifically, different government types — unified government and divided government — have affected U.S. policy toward North Korea. It particularly emphasizes the role of Congress and partisan politics in the making of U.S. policy toward North Korea.

This study finds that divided government played a pivotal role. Partisan politics are also central to the explanation: politics did not stop at the water's edge. A divided U.S. 
government produced more status quo policies toward North Korea than a unified U.S. government, while a unified government produced more active policies than a divided government. Moreover, a unified government with a Republican President produced more aggressive policies toward North Korea, whereas a unified government with a Democratic President produced more conciliatory policies. This study concludes that the different government types and intensified partisan politics were the main causes of the inconsistencies in the United States' North Korea policy that led to a nuclear North Korea. 


\section{TABLE OF CONTENTS}

CHAPTER

PAGE

I. INTRODUCTION 1

1.1. U.S. Policy on Nuclear Nonproliferation in General 5

1.2. U.S. Policy on North Korean Nuclear Nonproliferation 7

II. LITERATURE REVIEW AND RESEARCH DESIGN 13

2.1. The Debate on Unified Government vs. Divided Government 13

2.2. Research Design $\quad 26$

2.3. Conclusion 38

III. AMERICAN POLITICS AND FOREIGN POLICY 39

3.1. The Constitutional and Institutional Foundation of U.S. Foreign Policy 39

3.2. A Historical Overview of Divided Government 48

3.3. Conclusion 63

IV. THE PRESIDENCY, THE CONGRESS, AND U.S. POLICY TOWARD NORTH KOREA DURING THE CLINTON ADMINISTRATION 65

4.1. The Clinton Administration under Unified Government (1993-1994) 65

4.1.1. U.S. Policy toward North Korea during the Clinton Administration (1993-1994) 66

4.1.2. Presidency vs. Congress: Overview 73

4.1.3. Presidency vs. Congress: North Korea 76

4.2. The Clinton Administration under Divided Government (1995-2000) 80

4.2.1. U.S. Policy toward North Korea during the Clinton Administration (1995-2000) 81

4.2.2. Presidency vs. Congress: Overview 84

4.2.3. Presidency vs. Congress: North Korea 99

4.3. Conclusion 115

V. THE PRESIDENCY, THE CONGRESS, AND U.S. POLICY TOWARD NORTH KOREA DURING THE BUSH ADMINISTRATION 117

5.1. The Bush Administration under Unified Government (2001-2006) 117

5.1.1. U.S. Policy toward North Korea during the Bush Administration $\begin{array}{ll}\text { (2001-2006) } & 118\end{array}$

5.1.2. Presidency vs. Congress: Overview 130

5.1.3. Presidency vs. Congress: North Korea 141

5.2. The Bush Administration under Divided Government (2007-2008) 147

5.2.1. U.S. Policy toward North Korea during the Bush Administration $\begin{array}{ll}\text { (2007-2008) } & 148\end{array}$

5.2.2. Presidency vs. Congress: Overview 151

5.2.3. Presidency vs. Congress: North Korea 156

5.3. Conclusion 158 
VI. CONCLUSION

LIST OF REFERENCES

APPENDICES

VITA

201 


\section{LIST OF TABLES}

TABLE

PAGE

1. The Types of the U.S. Government, 1993-2008 34

2. The Government Types and North Korea Policy Outcomes, 1993-2008 36

3. Congressional Paths to Foreign Policy Influence 43

4. Divided Government since 1825

5. Phases of Divided Government in American History 58

6. Contract With America Scorecard 91

7. Executive Expenditures on KEDO vs. Congressional Appropriations, 1996-2002 103

8. U.S. Government Types and U.S. North Korea Policy 162 


\section{LIST OF ABBREVIATIONS AND ACRONYMS}

CVID Complete, Verifiable, Irreversible Dismantlement

DPRK Democratic People's Republic of Korea

HEU Highly Enriched Uranium

IAEA International Atomic Energy Agency

KEDO Korean Peninsula Energy Development Organization

LWR Light-Water Moderated Reactor

NKHRA North Korean Human Rights Act

NPT Treaty on the Non-Proliferation of Nuclear Weapons

NSSUSA National Security Strategy of the United States of America

PL Public Law

PSI Proliferation Security Initiative

UNSC United Nation's Security Council

WMD Weapons of Mass Destruction

WPA War Powers Act 


\section{INTRODUCTION}

The denuclearization of North Korea (officially, the Democratic People's Republic of Korea, or DPRK), the most important policy objective in U.S.-North Korea relations during the Clinton and Bush administrations, ultimately turned out to be a failure when Pyongyang conducted its first nuclear test in $2006 .{ }^{1}$ Both the William J. Clinton administration (1993-2000) and the George W. Bush administration (2001-2008) worked hard in an effort to avoid a nuclear North Korea. In so doing, they adopted a variety of policies toward North Korea, ranging from a possible use of military force to a negotiated settlement. Despite many years of hard work, however, their efforts did not prevent North Korean nuclearization.

During the first nuclear crisis between the United States and North Korea in 199394, President Clinton decided to negotiate with Kim Il Sung, the North Korean leader, after seriously considering a surgical air strike against to Yongbyon, the suspected nuclear site in North Korea. Clinton's decision to negotiate with North Korea resulted in the conclusion of the Geneva Agreement in 1994 that temporarily defused the crisis. Although Clinton continued to try to solve the North Korean nuclear issue diplomatically, he failed to fully live up to the 1994 Geneva Agreement, and to take further steps necessary for the improvement in the U.S.-North Korean relations including the normalization of the relationship between the two countries.

\footnotetext{
${ }^{1}$ North Korea also conducted a second nuclear test during the Obama administration in May, 2009.
} 
President Bush, especially after the September 11 terrorist attacks and during the second nuclear crisis between the United States and North Korea, took a more hostile stance toward the North Korean regime in general, and on the North Korean nuclear issue in particular. This confrontational position lasted for most of President Bush's time in office. Despite U.S. participation in the multiple rounds of the Six-Party Talks, the basic tenet of the Bush administration was not to negotiate with a member of "the axis of evil" until it dismantled all nuclear weapons and programs first, and not to reward bad behavior by "a rogue state." Such confrontational policy eventually led to a nuclear North Korea.

The central goal of the dissertation is to explain why, despite all their efforts to avoid the nuclearization of North Korea, both administrations failed to prevent Pyongyang from going nuclear. This is a crucial issue in U.S. foreign policy:

It is the story of an American foreign policy failure whose themes resonate well beyond North Korea: the breakdown of the global system of nonproliferation, the challenge of dealing with the nuclear ambitions of so-called rogue states, the fraying of American relations with key allies like South Korea and Japan, the erosion of the U.S. position in Asia, the emergence of China as a major player on the international stage, and the political manipulation of intelligence (Chinoy, 2008, xxi). 
To explain this failure, this dissertation examines the main causes of the implementation of different U.S. policy options toward North Korea during the Clinton and Bush administrations.

There are different — and often contrasting — views of the U.S. foreign and nuclear policy failure toward North Korea. Some argue that Clinton's appeasement policy has ultimately led to policy breakdown, while others argue that Bush's confrontational policy has eventually resulted in a nuclear North Korea. Most such criticisms, unsurprisingly, come from political or partisan interests. However, an understanding of the failure in U.S. North Korea nuclear policy should not be simply a matter of assigning blame.

Some argue that the policy inconsistency or incoherence between the Clinton and Bush administrations is a real culprit in the breakdown in U.S. North Korea policy. This view argues that whereas Pyongyang's policy toward Washington was consistent, Washington's policy toward Pyongyang was inconsistent, and that such inconsistency was a main cause of the failure of the US North Korea policy. ${ }^{2}$ They attribute the failure to contrasting policy approaches between the two administrations: nonproliferation vs. regime change, negotiation vs. confrontation, and constructive engagement vs. coercive diplomacy.

There are, however, some problems with this explanation. Although the Clinton and Bush administrations took different policy approaches, both shared common policy goals toward North Korea. It is true that President Clinton preferred constructive

\footnotetext{
${ }^{2}$ Leon V. Sigal (1998), for example, argues that North Korea's policy toward the United States has been consistent and easy to predict because it is based on a tit-for-tat strategy. Tong Kim (2010) also argues that North Korean "fundamental strategy has been consistent in pursuing the protection of their independence, the survival of their system, and the improvement of their economy." Furthermore, Charles K. Armstrong $(2006,19)$ argues that even during the Bush administration, "Pyongyang's negotiating position remained consistent."
} 
engagement to coercive diplomacy, while President Bush took a more confrontational stance. Both, however, embraced the denuclearization of North Korea as the most urgent and important policy goal. In addition, although both administrations viewed North Korean regime change as the best scenario, neither pursued this directly, because they considered it either undesirable or unattainable. Instead, both set nonproliferation of nuclear weapons as a realistic goal in North Korea policy.

This dissertation seeks to find out why the Clinton administration and the Bush administration chose different policy options toward North Korea, despite their common goal. It investigates how the relations between the executive and the legislative branches and, more specifically, the different government types—unified government where the same party controls both the executive and legislative branches and divided government where different parties control the executive and legislative branches- have affected the U.S. policy making process toward North Korea. ${ }^{3}$ In other words, it centers on the interbranch relationship between the president and the Congress and its impact on U.S. policy toward North Korea.

Although there is a large literature on the processes and outcomes of U.S. policy toward the North Korean nuclear issue from the presidential perspective and the executive branch's perspective (Sigal, 1998; Harrison, 2002; Cha \& Kang, 2003; Wit, Poneman, \& Gallucci, 2004; Lee, 2006; Pritchard, 2007; Chinoy, 2008), there have been relatively few efforts to understand the influence of different government types, and Congress in particular, on the making of U.S. policy toward North Korea. The few studies that have addressed those issues were limited to the Clinton administration or

\footnotetext{
${ }^{3}$ For more detailed discussions on the definitions, see the chapter II.
} 
dealt only with specific policy issues (Barilleaux \& Kim, 1999; Hathaway \& Tama, 2004; Lee $\&$ Miles, 2006). This project aims to provide a far more comprehensive perspective on the issue.

Different government types played a pivotal role in the United States' North Korea policy making process during the Clinton and Bush administrations, and the increase and the intensification of partisan politics during this period facilitated different policy outcomes. Politics did not stop at the water's edge, at least with regard to the U.S. policy toward North Korea. Different government types produced different policy choices, moreover, even though the two presidencies shared the same policy goal. The different government types and intensified partisan politics were the main causes that contributed to inconsistencies in U.S. North Korea policy and the ultimate policy failure.

\subsection{U.S. Policy on Nuclear Nonproliferation in General}

Nuclear nonproliferation has been one of the most important foreign policy goals of the United States since the end of the Second World War. The issue took precedence over many other U.S. foreign policy priorities. All postwar U.S. administrations made substantial efforts to prevent the spread of nuclear weapons and to strengthen the international nuclear nonproliferation regime. Since the United States used two nuclear bombs against Japan — the only such cases in world history—at the end of the Second World War, the nuclear nonproliferation policy has never lost its status as a top priority among U.S. foreign policy objectives. Whether it is to maintain nuclear domination or to 
make the world a safer and more secure place, it has never been questioned that nuclear nonproliferation is in the U.S. national interest. ${ }^{4}$

The spread of nuclear weapons is not in the U.S. national interest, because no states are immune from the threat of deliberate or accidental war. Moreover, states with weak civilian governments are especially likely to lack the positive constraining mechanisms of civilian control. Washington should thus stop the spread of nuclear weapons both by unilaterally exerting its influence over countries with nuclear ambitions and by multilaterally strengthening the global nuclear nonproliferation regime to reduce the possibility of the use of nuclear weapons against the United States.

During the Cold War, U.S. nuclear weapons policies consisted of nuclear deterrence toward nuclear powers and nuclear nonproliferation for all other states (Bunn \& Chyba, 2006, 298-99; Walker, 2000, 704-08). Non-state actors, such as terrorist groups, were not a focus of U.S. policy at the time.

Since the end of the Cold War, however, loose nukes, nuclear smuggling, and nuclear terrorism began emerging as new threats to the United States. ${ }^{5}$ Washington was afraid that nuclear weapons, weapons materials, or weapons technologies could be transferred to rogue states and terrorist groups. Although nonproliferation was always an important consideration in U.S. foreign policy, since the end of the Cold War, "it has achieved top billing on almost all lists of foreign policy and defense priorities (Mazarr, 1995, 4)." The fear that terrorist groups would acquire weapons of mass destruction was highlighted by the September 11 terrorist attacks. After the attacks, the Bush

\footnotetext{
${ }^{4}$ For more detailed descriptions on the history of US nuclear policy, see Freedman, 2003.

${ }^{5}$ For a contemporary concern on a revolutionary change in nuclear nonproliferation environment since the end of the Cold War, see Simpson, 1994.
} 
administration strengthened its nonproliferation policy, and even extended counterproliferation actions by implementing the Proliferation Security Initiative (PSI), under which merchant ships at sea could be stopped for inspection if suspected to carry weapons of mass destruction.

\subsection{U.S. Policy on North Korean Nuclear Nonproliferation}

For the past two decades, the most important goal in U.S. policy toward North Korea has been the denuclearization of Pyongyang. Successive U.S. administrations have clearly indicated that their top priority was the complete elimination of North Korean nuclear weapons and programs. In order to achieve this goal, Washington has gone to great lengths to prevent North Korea from going nuclear by adopting a variety of policies both bilaterally and multilaterally. These policies have included bilateral negotiation, multilateral negotiation, bilateral economic sanctions, multilateral economic sanctions, coercive diplomacy, and the threat to use force.

The United States has seen a nuclear North Korea as a fatal failure of the nuclear nonproliferation regime. Because of U.S. efforts and leadership, most states have subscribed to the regime. The United States had three major fears about a nuclear North Korea. The first fear was that Pyongyang might use nuclear weapons to threaten American security and interests, especially installed and delivered by North Korean ballistic missiles. The second fear was that "if the North is not stopped, a terrible precedent for violating the nonproliferation regime will have been set and another possible source for transfers of nuclear technology that promote proliferation, or even the 
terrorist use of nuclear weapons, will have emerged" (Morgan, 2007, 25). The third fear was that the North would destabilize the balance of power in Northeast Asia and increase the level of tensions by creating a regional nuclear arms race.

The North Korea nuclear proliferation issue was initiated in 1989, when the CIA reportedly obtained evidence proving North Korea's capability of developing nuclear weapons on its own. The U.S. fears reached a peak in 1993-4, when Pyongyang threatened that it would withdraw from the NPT (the Treaty on the Non-Proliferation of Nuclear Weapons or Nuclear Non-Proliferation Treaty), decided to pull the fuel rods from a reactor, and announced that it would withdraw from the IAEA (the International Atomic Energy Agency). By signing the Agreed Framework in Geneva, Switzerland, on October 21, 1994, however, North Korea temporarily defused the issue. During this first nuclear crisis, the Clinton administration pursued a policy of constructive engagement with North Korea for the purpose of nuclear nonproliferation. "This conciliatory posture was based on the classic liberal assumption that even with dictatorial countries, mutually beneficial discussions could be conducted and reasonable compromises could be reached in good faith" (Lee, 2006, 160). Despite its conclusion with the Agreed Framework in 1994, however, the Clinton administration was either unable or unwilling to fully implement it due mainly to the resistance of the Republican majority in Congress. ${ }^{6}$

The North Korea nuclear proliferation issue was revived in October, 2002, when North Korea reportedly admitted its covert nuclear development. The Bush administration then asserted that North Korea violated the 1994 Agreed Framework. President Bush argued, "The United States honored its side of the agreement. North

\footnotetext{
${ }^{6}$ The Republican Party won the 1994 mid-term elections and became majorities in both houses of Congress.
} 
Korea didn't. While we felt the agreement was in force, North Korea was enriching uranium" (The White House, 2003). The Geneva Agreement was nullified. The September 11 terrorist attacks, without a doubt, also greatly influenced the Bush administration's North Korea policy. The Bush administration became more confrontational toward North Korea. The 2001 Nuclear Posture Review identified North Korea as a state that might be attacked by U.S. nuclear weapons in an immediate contingency (Department of Defense, 2001, 16). The Bush administration demanded CVID—complete, verifiable, irreversible dismantlement—as a precondition for a negotiation with North Korea. Five years later, despite the intermittent negotiations between the United States and North Korea through the Six-Party Talks, Pyongyang finally conducted a nuclear test in October, 2006.

The Bush foreign policy team criticized the 1994 Agreed Framework as an appeasement or a reward for bad behavior. They denounced Clinton's policy toward North Korea as "deeply, profoundly misguided and wrong" (as cited in Martin, 2007, 85). The 2001 Nuclear Posture Review developed contingency plans for using nuclear weapons on the Korean peninsula, and the 2002 National Security Strategy emphasized the possibility of preemptive military strikes against countries with WMD. In his 2003 State of the Union speech, President Bush labeled North Korea part of the "axis of evil". Furthermore, the Bush administration was opposed to providing any political and economic incentives that would help to maintain this "evil" regime in exchange for denuclearization.

The Clinton and Bush administrations, nevertheless, had in common two core strategic objectives on the Korean peninsula and in the East Asian region: nuclear 
nonproliferation and the peace and security of the region. The first goal of the Clinton and Bush administrations was to prevent the spread of nuclear weapons by a rogue state in the region, North Korea. When Clinton took office in the early 1990s, his administration expressed "its firm commitment to halting the spread of nuclear weapons and other weapons of mass destruction, to strengthen the functions of the International Atomic Energy Agency (IAEA), and to enforce strong sanctions against governments that violated international agreements" (Lee 2006, 159).

In the 2002 National Security Strategy of the United States of America (The White House, 2002b, 14), President Bush also stated that a new comprehensive strategy requires "strengthened nonproliferation efforts to prevent rogue states and terrorists from acquiring the materials, technologies, and expertise necessary for weapons of mass destruction (emphasis added)." In addition to the use of nuclear weapons against the United States or the sale of nuclear weapons to other states or terrorist groups, Washington did not want the domino effect of the nuclear arms race in Asia. A nuclear North Korea would trigger nuclear arms race in the region involving Japan, South Korea, China, Taiwan, even India and Pakistan.

The second strategic goal in common was the maintenance of the stability and peace in the East Asian region, especially considering the geopolitical and economic strategic significance of a region including China, Taiwan, Japan, and two Koreas. As Carpenter \& Bandow (2004) point out:

The nations of East Asia have a large population, significant military forces, and an impressive (and growing) array of economic and technological capabilities.... 
East Asia is now the most significant region for U.S. international commerce, having surpassed Western Europe in the 1990s. Ten of America's 24 largest trading partners are located in the region (Japan, third; the People's Republic of China [minus Hong Kong], fourth; the Republic of Korea, seventh; Taiwan, eighth; Singapore, tenth; Malaysia, twelfth; Hong Kong, sixteenth; Thailand, nineteenth; the Philippines, twenty-third; and Australia, twenty-fourth). Many of those same entities also provide important arenas for American investment. Maintaining, indeed strengthening, that array of economic ties constitutes an interest that Washington cannot ignore (148).

In addition, according to the World Development Indicators database, in 2008, the aggregate of GDPs of only three East Asian countries, China, Japan, and South Koreaeven without including Taiwan and North Korea - was 16\% of the total GDP of the World (The World Bank, 2009).

The Clinton administration thus argued that the United States should actively engage the region to promote both its political stability and its economic prosperity (Nye, 1995). In 1994, Secretary of Defense William Perry said that North Korea was the biggest threat to the stability and peace in the region because of its "excessive military force.” He specifically stated, “An unchecked nuclear capability—coupled with North Korea's large conventional military forces - could put North Korea in a position to subject South Korea to extortion in establishing its terms for unification. It could undermine the security of the whole Northeast Asia region and tempt other countries to 
seek their own nuclear weapons in self-defense" (as cited in Lee, 2006, 170). ${ }^{7}$ During the Bush administration, the U.S. Department of State also stated that Washington's "interests in the East Asia-Pacific region concern promoting regional stability, fostering democracy and human rights, encouraging economic prosperity, furthering cooperation on fighting transnational issues and international crime, and preventing the proliferation of weapons of mass destruction (Department of State Regional Topics, 2005)." To stop the nuclearization of North Korea, therefore, was regarded as the most pivotal policy goal both for the Clinton administration and for the Bush administration in achieving their two core strategic objectives on the Korean peninsula and in East Asia.

\footnotetext{
${ }^{7}$ In 1994, General Gary Luck, commander of U.S. Forces Korea, also projected that "a war in Korea would kill or would as many as 52,000 U.S. troops and 490,000 South Korean military forces and would cost \$61 billion in the first ninety days; a prolonged full-scale war would kill or wound about a million people, including 80,000 to 100,000 U.S. troops as a cost of $\$ 100$ billion — about one-third of the annual U.S. defense budget" (Lee, 2006, 171).
} 


\section{LITERATURE REVIEW AND RESEARCH DESIGN}

Different institutional settings react differently to international affairs. Regarding U.S. foreign policy, one of the most important institutional settings is different government types: unified government and divided government. The struggle for control over foreign policy making between Congress and the president is most evident in the divided government. To understand how different government types impact U.S. foreign policy, many studies have examined the consequences of different government types on foreign policymaking process. This chapter will review key debates on the role of different government types in the making of U.S. foreign policy and delineate research design of this dissertation.

\subsection{The Debate on Unified Government vs. Divided Government}

The tension between the executive and the legislative branches is a recurring theme in the study of the U.S. political system. The U.S. Constitution invites a struggle for power both in the domestic policymaking and in the foreign policy making (Corwin, 1957; Franck, 1981; Spanier \& Nogee, 1981; Tower, 1981/2; Christopher, 1983; Crabb \& Holt, 1989; Mezey, 1989; Warburg, 1989; Neustadt, 1990; Cox \& Kernell, 1991; Lindsay \& Ripley, 1992; Rosner, 1995; Campbell, Rae, \& Stack, 2003; Kelley, 2005; Thurber, 2006; Fisher, 2007; Lindsay, 2007). With particular regard to U.S. foreign policy, Hersman (2000) states that: 
Few aspects ... are more contentious or controversial than the respective roles and responsibilities of Congress and the executive in the foreign policy process.

Despite the voluminous efforts of scholars to understand and explain the perpetual conflict and confusing processes that drive executive-legislative relations over foreign policy, the debate persists (1).

Some topics have attracted more attention than others. One that has received particular attention is the question of which branch makes U. S. foreign policy. ${ }^{8}$ Some argue that Congress prevails (Cutler, 1980; Szamuely, 1987; Jones \& Marini, 1988; Crovitz \& Rabkin, 1989; Cheney 1990), while others argue that Congress has lost its willpower in the competition with the President, especially in the foreign policy decision making process (Schlesinger, 1973; Berkowitz, Bock, \& Fuccillo, 1977; Koh, 1988; Hinckley, 1994; Peterson, 1994b; Peterson, 1994c; Weissman, 1995; Wolfensberger, 2002; Ornstein \& Mann, 2006; Ohaegbulam, 2007; Fisher, 2008; Cooper, 2009; Hansen \& Friedman, 2009).

Although many studies show that Congress has become more active, assertive, and aggressive in U.S. foreign policy making since Vietnam (Franck \& Weisband, 1979; Sundquist, 1980; Ripley \& Lindsay, 1993; Scott \& Carter, 2002), the large picture is that interbranch relations have rather been "fluid and dynamic, with neither Congress nor the president always predominant" (Rosati \& Scott, 2007, 313). Many other studies confirm Rosati and Scott's (2007) judgment that Congress has long played an important role in

\footnotetext{
8 "Since World War II, Congress has been characterized as acquiescent, resurgent, deferent, assertive, subservient, coequal, and imperial" (Carter \& Scott, 2010, Web).
} 
the U.S. foreign policy making process, competing with the Presidency sometimes, cooperating with it at other times (Manning, 1977; Lindsay, 1992/3; Henkin, 1996;

Burgin, 1997; Martin, 2000; Cater \& Scott, 2004; Howell \& Pevehouse, 2005; Howell \& Pevehouse, 2007; Carter \& Scott, 2009). LeLoup \& Shull (2003) identify four different policy outcomes: presidential leadership in the Persian Gulf War in 1991, congressional leadership in Cuba sanctions legislation in 1996, consensus/cooperation in the Panama Canal treaties in 1978, and deadlock/extraordinary resolution in aid to the Nicaraguan contras in 1982-89.

A second interesting topic is whether politics stops at the water's edge. A major finding is that partisan politics in Congress has begun to increase as bipartisan support on a variety of foreign policy issues has significantly decreased since the Vietnam War. Such partisanship has continued and even increased since the end of the Cold War (Bond \& Fleisher, 1990; McCormick \& Wittkopf, 1990; Meernik, 1993; Sinclair, 1993; Rohde, 1994, Cooper \& Young, 1997; McCormick, Wittkopf, \& Danna, 1997; Carter, 1998; Wittkopf, \& McCormick, 1998; Pleisher, Bond, Krutz, \& Hanna, 2000; Delaet, Rowling, \& Scott, 2005; Pfiffner, 2006; DeLaet \& Scott, 2006). Such partisan politics may facilitate or hinder the different choices in U.S. policy toward North Korea.

In the meantime, since the 1990s, particularly after Sundquist (1988/9) raised the question on which type of government should be "the superior model for America" (634), because "the country passed from a long era of party government, when either the Republican or the Democratic Party controlled both the presidency and the Congress almost all of the time, to an era when the government was divided between the parties most of the time" (614), numerous studies on the consequences of different government 
types—unified government and divided government—-both on domestic policymaking process and on foreign policymaking process have been followed to address the issue.

Lindsay and Ripley (1992) also encouraged political scientists to fill the gap between the increasing popular interest in divided government and the lack of analytical study of it. The intense ideological struggle and violent partisanship between the Republican Party and the Democratic Party in the 1990s also contributed significantly to the emergent discussion on the role of congress and of the divided government in U.S. foreign policy making.

There has been, however, no consensus with regard to the effect of the different government types on U.S. foreign policy. Some argue that whether the government is divided or unified does not make much difference in foreign policy making process. Mayhew (2005) suggests that "it does not seem to make all that much difference whether party control of the American government happens to be united or divided" (198). Fiorina (1996a; 1996b) also argues that there were no significant differences between years of unified government and years of split control, and that claims that divided government leads to policy stalemate or policy gridlock are unfounded.

In a similar vein, Jones (2005) points out that the United States has been skillfully governed "under the strikingly diverse constitutional arrangements of single- and splitparty control" (32), and that the U.S. political system of "mixed representation and shared powers" (359) has competently functioned. Finally, Menefee-Libey (1991), Thurber (1991), Paul E. Peterson (1994a), Alesina \& Rosenthal (1995), Gowa (1998), Krehbiel (1998), Binder (2001), Fordham (2002), and Auerswald \& Maltzman (2003), all find little or no evidence for the negative impact of divided government on U.S. foreign policy 
making processes and outcomes. To quote Menefee-Libey (1991), “divided government is not the real problem" (643).

Others, however, argue that divided government makes difference, that it has significant impacts both on domestic and on foreign policymaking, and that it has a tendency to lead to more partisan politics and ideological conflicts in Congress. Ware (2001) argues that "as much substantive legislation appears to have been passed under divided government as under unified government. Nevertheless, it is only in particular kinds of circumstances, that the relationship between the two branches under divided government can be described as being one of constructive engagement” (33). Kelly (1993) concludes that "divided government does make a difference" (emphasis in original, 483). LeLoup \& Shull (2003) note, "While divided government does not always paralyze policymaking... it does make a difference" (10). Conley (2003) suggests divided government "does matter for the legislative presidency" (emphasis in original, 3). Carter $\&$ Scott (2004) also conclude that the implications of their study reflect "the obvious importance of divided government" (59).

Secondly, some argue that divided government has significant impacts on U.S. policymaking. Lohmann \& O’Halloran (1994) claim that "partisan control... significantly affected presidential and congressional policymaking" (628). Howell \& Pevehouse (2005), in their study, suggest that divided government "critically affects presidents' proclivity to use military force" (228). O’Halloran (1994) concludes that "divided government has a subtle but important effect on policy through the willingness of Congress to design procedures that delegate authority to the president" (180). 
Others further argue that divided government has negative impacts on the US policymaking. Mezey (1989) argues that "the political system has become increasingly disposed toward stalemate" (147). Kernell (1991) claims that "a divided government will require the president to draw heavily upon his constitutional prerogatives as he defends his party's positions against the designs of the opposition-controlled Congress" (108). Binder (1999) also finds that "[Policy] deadlock is more likely when the two major parties split control of Congress" (527). Edwards, Barrett, \& Peake (1997) point out that “divided government inhibits the passage of important legislation" (562). Destler (2001) concludes that divided government has been detrimental to U.S. foreign policy.

Finally, divided government intensifies congressional activism and violent partisan politics. Meernik (1995) argues that Congress is more likely to attempt to restrict the presidential use of force under divided government. Scott \& Carter (2002) also argue that divided government has affected levels of congressional activity in the post-World War II era, leading to a decline in congressional activity. McCormick, Wittkopf, \& Danna (1997) argue that "divided government contributed to the decline in bipartisanship by accentuating the rise of ideological differences..., while [u]nified government contributes to bipartisan decline in a different way, by fostering partisan divisions, especially as the experience of the Clinton administration in the House during the $103^{\text {rd }}$ Congress reveals" (146). Many studies also show that divided government escalates the tendency of partisanship and ideological disputes on a variety of foreign policy issues. Carter (1998) concludes that "the phenomenon of divided government further escalates 
the impact of an increasingly partisan and ideological policy making process" (128). ${ }^{9}$ In sum, different government types evidently influence a variety of U.S. foreign policy issues in a different way (Mann, 1990: McCormick, Wittkopf, \& Danna, 1997; Martin, 2000).

As discussed briefly earlier, another important discussion on the nature of the interbranch relations between the Presidency and the Congress in U.S. history is the increase and intensification of party politics and partisanship in Congress. It is commonly assumed that politics stops at the water's edge and Congress supports the president on foreign policy issues (Wildavsky, 1966). Partisan politics in Congress has begun to increase, however, as bipartisan support on a variety of foreign policy issues and a Cold War consensus in American politics have decreased since the Vietnam War. ${ }^{10}$ This issue is particularly important because such partisan politics may make possible or impossible the specific choices in U.S. policy toward North Korea.

Divided government since the Vietnam War and especially since the end of the Cold War has become fertile soil for intensified party politics and partisanship in Congress, as a Cold War consensus diminished that was a crucial element in minimizing the impact of divided government on U.S. foreign policy making in the 1950s and 1960s.

\footnotetext{
${ }^{9}$ In the meantime, Silbey (1996) interestingly argues, "What we really have now is not divided but fragmented government," because "divided government can exist only when there is a clear and dominant pattern of national two-party competition and when each party stands for different policies, so that when the government becomes divided along party lines, there will be a predictable, clear-cut policy conflict. Fragmented government, in contrast, exists when the parties are weak and voters and legislators do not receive or welcome sustained and meaningful partisan cues and are extremely volatile in their behavior most of the time, whatever their occasional deviations from that anarchic norm" (20).

10 "Gosh, I miss the Cold War," said President Bill Clinton in late 1993" (as cited in Scott \& Crothers, 1998, 1). The utterance very amusingly reflects the difficult situation of presidential leadership on foreign policy issues with increased partisanship and the decreased foreign policy consensus in Congress since the end of the Cold War.
} 
However, some argue that, even during the Cold War era, congressional partisanship was often apparent on a variety of issues, including the direction of U.S. foreign policy (Howell \& Pevehouse, 2007). McCormick \& Wittkopf (1990) also examine two contrasting perspectives on the nature of congressional-executive relations in U.S. foreign policy making: the bipartisan perspective, which argues that politics stops at the water's edge, and the political perspective, which claims that foreign policy is subject to partisan and ideological disputes. They conclude that "the bipartisan perspective applies best to the first two decades of the postwar era, but that it has not been replaced by the political perspective..." because "the political perspective applies throughout the postwar era" (1097).

Numerous studies show, on the other hand, since the Vietnam War, partisanship has significantly increased and started to affect not only congressional decisions such as the choices of party leaders, the voting of rank-and-file members, and the behavior of individual members of Congress, but also presidential decisions such as the use of military force, making executive agreements and treaties, enacting economic sanctions, and providing food assistance.

To refute MaCormick \& Wittkopf (1990)'s argument that the Vietnam War did not play a significant role in congressional bipartisan support of the presidency and that congressional bipartisan Cold War consensus was not as prominent as many had assumed, Meernik (1993) develops "a comprehensive model of bipartisan congressional support of presidents from 1947 through 1988, examining foreign policy and defense roll-call votes to determine what factors lead Republicans and Democrats to overcome their political differences on these issues" (570). 
Meernick (1993) concludes that "there was a strong degree of bipartisanship in congressional support of presidents on foreign policy and defense issues before America's involvement in Vietnam. After this conflict, consensus broke down and was replaced with much more conflictual voting behavior" (585). With regard to the argument by McCormick and Wittkopf that partisanship existed even during earlier years, Meernik points out that "such conflict was not nearly as visible, frequent, and deep as it has been in later times" (585). He predicts that "without any strong incentives for stopping politics at the water's edge, the president and the Congress will in all probability continue to shape foreign policy according to their own political needs" (586).

In a similar vein, Rohde (1994) argues that although, until the mid-1960s, "bipartisanship on matters related to international affairs was both a goal and a fact of presidential-congressional politics..., [t]his pattern of consensus and deference was broken by conflict over the Vietnam War and other international affairs issues during the Johnson and Nixon administrations in the late 1960s and early 1970s" (76). Carter (1998) also argues, "since the Vietnam War, no consensus regarding the preferred ends and means of U.S. foreign policy and defense policy has existed to dampen the effects of ideology and partisanship. These factors have increasingly reinforced each other, making the parties more ideological" (128).

Many studies argue such partisanship has further intensified with the end of the Cold War. Cooper \& Young (1997) examine three basic voting patterns — partisanship, bipartisanship, and crosspartisanship - to see "whether the strength of party voting has incrased or declined in the twentieth century" (247). They conclude that the Congress- 
both the House and the Senate- has become more partisan in the post-Cold War period, even if it remains to be seen whether the country has truly entered a partisan era.

McCormick, Wittkopf, \& Danna (1997) also extend their earlier study of the nature of congressional-executive relations in U.S. foreign policy making (McCormick \& Wittkopf, 1990) to the Bush and Clinton administrations. They conclude "that bipartisanship has continued to wane in the post-Cold War era and that the political perspective is an increasingly powerful interpretation of congressional-executive relations in foreign policymaking" (146). The level of bipartisanship during the Bush and Clinton administrations has reached new low points, while the partisan gap on foreign policy votes remained very wide.

One apparent consequence of increased partisanship since the end of the Cold War is that Congress has become more assertive and aggressive. Carter (1998) argues that in the post-Cold War era, members of Congress "were more assertive" (emphasis original, 110). According to him, it is not surprising since:

Partisanship is a major component of a member's reaction to the internal political environment in which that legislator works. Both chambers of Congress are organized along partisan lines, and members tend to interact and socialize with their chamber colleagues along partisan lines. Moreover, party organizations control access to both committee and subcommittee assignments and to personal and committee staff resources. Party leaders control the legislative schedule and service the needs of their respective party members. In addition, there may be costs to resisting party leaders' requests and rewards for "doing the right thing" in 
party leaders' eye. Thus partisanship affects just about every aspect of the human setting within Congress, and so it impacts the foreign policy-making process as well (127-28).

Carter thus concludes that "the cold war's end brought another escalation in the level of congressional assertiveness in foreign policy making" (129). Scott \& Carter (2002) also argue that Congress has become more assertive since World War II. They examined congressional foreign policy activity from 1946 to 1997 to gauge the competing claims between the resurgence school (which argues that presidential leadership on foreign affairs has been eroded by increased congressional activity: Franck \& Weisband, 1979; Destler, Gelb, \& Lake, 1984; Holsti \& Rosenau, 1984; Melanson, 1996), and the acquiescence school (which holds that congressional activity declined: Hinckley, 1994). ${ }^{11}$ Scott \& Carter (2002) conclude that "Congress has become less active but more assertive in its foreign policy behavior since World War II" (163).

Many studies show that both members of Congress (Wittkopf \& McCormick, 1998; Carter \& Scott, 2004; Delaet \& Scott, 2006; Layman, Carsey, Green, Herrera, \& Cooperman, 2010) and congressional party leaders have been ideologically polarized (Sinclair, 1993; Smith 1994). The increased partisanship noted by so many scholars can also be observed in congressional voting behavior (Fleisher, Bond, Krutz, \& Hanna, 2000; Delaet, Rowling, \& Scott, 2005).

\footnotetext{
${ }^{11}$ Hinckley (1994) argues that the assertive role of Congress in the making of U.S. foreign policy is a myth and that a struggle for influence between the two branches is an illusion. According to her, the underlying trends are masked by a host of surface activities of Congress such as the increase number of bills and the number of hearings, the proclamations and symbolic resolutions, steadily mounting number of congressional reports, and symbolic struggle between the Congress and the president with filibusters, veto threats, and last-minute compromises. For more details, see Hinckley, 1994.
} 
In the meantime, many studies show that presidential success in Congress depends on the factors such as partisanship and ideology, because "all other things being equal, members of the president's party will look for reasons to support his foreign policy requests and members of the opposition party will look for reasons to oppose them" (Carter, 1998, 128). Bond \& Fleisher (1990), by analyzing presidential success in Congress and the conditions that contribute to success by dissecting roll votes in Congress between 1953 and 1984, conclude that "presidential success on roll call votes from 1953 to $1984 \ldots$ support the Congress-centered thesis rather than the one emphasizing presidential variables" (222). Their findings thus indicate that during this period, "members of Congress provide levels of support for the presidents that are generally consistent with their partisan and ideological predispositions" (223). Fleisher, Bond, Krutz, \& Hanna (2000) argue that "in the American system of separation of powers, elevated partisanship makes majority presidents more successful and minority presidents less successful" (6). They show that "the level of success for minority party presidents on foreign and defense votes has declined" (21). These arguments consist of important theoretical foundations of the hypotheses which will be developed and delineated in the next section of this chapter, and will be applied and discussed in more detail in the chapters IV and $\mathrm{V}$ of this dissertation.

Finally, there have been many studies examining the major causes of the decreased bipartisanship and the increased partisanship in the post-Vietnam War period and in the post-Cold War period (Pfiffner, 2006). Destler (2001) argues that "the most durable cause of Congress's willingness to challenge the president... is the polarization of party politics in the United States (328)." According to him, “American political 
leaders have been spending less time seeking a viable consensus in the center, and more time fighting for partisan and ideological advantage" (328). Carter (1998) argues that "the lack of a foreign policy consensus in society, the phenomenon of divided government, the increasingly ideological and partisan nature of foreign and defense policy debates on Capitol Hill, the decreasing influence of standing committees and the increasing influence of party leaders on both sides of the aisle combine to present a formidable challenge to presidents" (131). Theriault (2008) argues that "only when the changes within the constituency interact with the legislative process does the complete picture of party polarization in the U.S. Congress come into clearer focus" (6).

In sum, whether the major causes of the decreased bipartisanship and the increased partisanship are individual, structural, or procedural, it is undisputable that partisan politics has contributed to nearly every foreign policy clash between Capitol Hill and the White House for the past five decades. Partisan politics in Congress has begun to increase since the Vietnam War, and it dramatically intensified since the end of the Cold War. As we have seen above, indeed, the influence of the increased and intensified partisanship in Congress is to be found almost everywhere: presidential decisions, individual members of Congress, congressional party leaders, the congressional voting behaviors, and so on. Divided government since the Vietnam War and since the end of the Cold War as well has become a fertile ground for more intensified party politics and partisanship in Congress. The lack of consensus on foreign policy issues, the accelerated process of globalization and the subsequent increase of intermestic issues, the frequent divided party control of government, and polarized ideological separation between the 
Republicans and the Democrats, all contributed the increase and intensification of partisan politics in Congress.

This dissertation will focus attention on the role of different government types on U.S. foreign policy, and specifically at the impact of different government types on the U.S. North Korea nuclear policy. In so doing, it will ask which thesis- "politics stops at the water's edge" or "politics proceeds past the water's edge"-is more persuasive during the Clinton and Bush administrations, and how much partisanship and ideological politics affected and were responsible for the case. The weight of previous research shows a clear trend toward the latter perspective. Yet North Korea is a hard case, since even partisans might be expected to share negative views of this so-called pariah state. ${ }^{12}$ It is evident that not only members of Congress from both parties, but also presidents from both parties have shared similar critical perceptions on the North Korean regime under Kim Il Sung and Kim Jong Il.

\subsection{Research Design}

For analytic purposes, the domestic sources of U.S. foreign policy can be divided into three categories, the societal factors, the institutional factors, and the individual factors. Societal influences on U.S. foreign policy include political culture, elite and public opinion, political parties, the media, and interest groups. Institutional factors involve the executive and legislative branches of government and the executive

\footnotetext{
${ }^{12}$ For example, the North Korean Human Rights Act in 2004 passed the Senate by unanimous consent, and the House by voice vote (The Library of Congress, 2004).
} 
departments and other agencies dealing with foreign policy issues. Finally, individual factors comprise the personal characteristics of individuals and the role responsibilities of foreign policy decision makers (Wittkopf and McCormick, 2008; See also Scott and Crothers, 1998, 2-13.).

Among these three domestic sources of foreign policy, this project focuses on the institutional factors. This is not because the other sources are not important, but because institutional factors are the most persistent influences on foreign policy. Societal and individual factors seem to be more changeable. Secondly, different institutional settings react differently to foreign affairs. In the United States, the struggle for control over foreign policy making between Congress and the president is most evident in the divided government. Thirdly, societal factors are less important than institutional factors because there is no strong interest group in the United States to publicly represent North Korea. Lastly, although individual factors could have played an important role, they do not explain the phenomenon in which this dissertation is interested. Individual factors explain neither the changes in Clinton's North Korea policy nor the differences in Bush's North Korea policy during their terms, respectively. In other words, institutional factors "have more effects on foreign policy, they tend to influence actors more than actors influence them, and their impact is independent of the regime type or the decision making actors" (Carter \& Scott, 2010, Web). ${ }^{13}$

\footnotetext{
${ }^{13}$ Institutional factors - more specifically, governmental structures - "generate specific roles that would be likely to occur irrespective of the idiosyncrasies of the role occupants" (J. N. Rosenau, 1966, 43, as cited in Carter \& Scott, 2010, Web). However, Rosenau does not underestimate the importance of individuals in international affairs. According to him, "it is misleading to think of world affairs as being driven exclusively by large collections... Such macro organizations are surely central to the course of events, but so are people at the micro level” (J. N. Rosenau, 2008, 2).
} 
With regard to U.S. policy toward North Korea, interbranch relations between Congress and the president during the Clinton and Bush administrations have become more important than before. This dissertation limits its time period to the Clinton and Bush administrations (1993-2008), because the North Korean nuclear crisis began in earnest in 1993 during the Clinton administration and North Korea ultimately conducted its first nuclear test in 2006 during the Bush administration. Moreover, these two administrations provided a nice paired comparison with every permutation of divided and unified party control.

To understand why the Clinton administration and the Bush administration chose different policy options toward North Korea in spite of their common policy goals of the denuclearization of Pyongyang, it is instructive to consider Robert Putnam's (1988) theory of two-level games.

According to the two-level game model, it is wrong to ignore or underestimate the role of Congress in the foreign policy making process in the United States, because many foreign policy outcomes come as a result of the interaction between international factors and domestic factors and, among many other domestic factors, the interbranch relationship plays the most significant role. Robert Putnam (1988) suggests two-level games as a model for domestic-international interactions to make sense of the process and outcome of the international bargaining. Putnam (1988) notes that:

At the national level, domestic groups pursue their interests by pressuring the government to adopt favorable policies, and politicians seek power by constructing coalitions among those groups. At the international level, national 
governments seek to maximize their own ability to satisfy domestic pressures, while minimizing the adverse consequences of foreign developments. Neither of the two games can be ignored by central decision-makers, so long as their countries remain interdependent, yet sovereign (434).

Many agree that in order to understand international negotiation, one should take in consideration both the international and intranational factors. Bruckman (1978) argued that a negotiator has dual responsiveness or boundary-role conflict (BRC) with bargaining and representation, described as two-track negotiating-i.e., negotiating simultaneously with the bureaucracy and with the other side. Negotiators as bargainers respond to their counterparts; negotiators as representatives respond to their own constituents. Whereas the former emphasizes international interactions, the latter focuses on intranational interactions. However, these two types of activities together constitute international negotiation.

Smith (1998) also argued, "when forming foreign policies, leaders simultaneously balance these internal and external constraints. Hence, international events and domestic political survival are intrinsically linked, not through a simple unidirectional causal pathway, but via a serious of strategic interactions at both the international and the domestic level" (633). Moravcsik (1999) also held that the most distinctive feature of the two-level game model from other theories is the fact that "the statesman's strategies reflect a simultaneous 'double-edged,' calculation of constraints and opportunities on both the domestic and international boards" (17). 
In the two-level game model, the size of the win-sets, which are defined as "the set of all possible agreements that would win" (Putnam, 1988, 437), is crucial for an international negotiation to reach a mutual agreement. To examine the size of the winsets, Putnam decomposed the negotiation process into two stages, Level I and Level II: bargaining between the negotiators and separate discussions within each group of constituents. To understand Level I negotiations, it is essential to recognize the implications of the Level II win-sets, the necessary majority among the constituents when simply voted up or down" (Putnam, 1988, 437). The size of the win-set depends on the distribution of power, preferences, and possible coalitions among Level II constituents, on the Level II political institutions or ratification procedures, and finally on the strategies of the Level I negotiators. ${ }^{14}$

For chief negotiators, there are two ways to help reach an agreement in international negotiations. One way is to expand the win-set range in Level I, because the more the win-sets overlap, the easier agreements can be reached. Another is to expand the domestic constituents' win-sets in Level II, for agreements in Level I still need to be ratified or approved in Level II. In two-level bargaining, however, the chief negotiator will particularly be perceptive and careful with the domestic constituents' constraints and demands. ${ }^{15}$ In the case of the United States, presidents as chief negotiators cannot ignore

\footnotetext{
14 "Ratification" may entail a formal voting procedure at Level II, such as the constitutionally required twothirds vote of the U.S. Senate for ratifying treaties, in this dissertation, however, the term generally refers to any decision-process at Level II that is required to endorse or implement a Level I agreement, whether formally or informally (Putnam, 1988, 436).

${ }^{15}$ Expectation effects are also remarkably significant in this sequential decomposition into a negotiation phase and a ratification phase, because there are likely to be prior consultations to hammer out an initial position for negotiations. In fact, the need for Level II ratifications seriously influences the Level I bargaining. Furthermore, expectations of rejection at Level II may abort negotiations at Level I even
} 
or underestimate the pressures from Congress, both because that they also have to function as politicians to acquire, maintain, and strengthen their own political authorities, and because that the Congress is the most powerful domestic political organization mandated by American Constitution to share powers on foreign policy with the presidents.

Putnam also argues that "the chief negotiator will normally give primacy to his domestic calculus, because his own incumbency often depends on his standing at Level II. Hence, he is more likely to present an international agreement for ratification, the less of his own political capital he expects to have to invest to win approval, and the greater the likely political returns from a ratified agreement" (Putnam, 1988, 457). In a similar vein, Bueno de Mesquita et al. (2003) introduce a theory of political survival to examine policy outcomes of political leaders. They (2003) argue that:

Every political leader faces the challenge of how to hold onto his or her job. The politics behind survival in office is, we believe, the essence of politics. The desire to survive motivates the selection of policies and the allocation of benefits; it shapes the selection of political institutions and the objectives of foreign policy; it influences the very evolution of political life. We take as axiomatic that everyone in a position of authority wants to keep that authority and that it is the maneuvering to do so that is central to politics in any type of regime (8-9).

without any formal action at Level II before the Level I negotiations. More often than not, the constituents' views may themselves evolve in the course of the negotiations (Putnam, 1988, 436). 
Regarding U.S. negotiations with North Korea on the nuclear issue, Washington had a very limited win-set at Level I, as a result of Pyongyang's uncompromising attitudes that offered few or no concessions. Washington also failed to expand the winsets at Level II, not least because of its domestic partisan politics. As a result, "the United States has had a frequent mismatch between what was negotiable internationally and what could be suitably ratified domestically with respect to North Korea" (Morgan, 2007, 29).

To understand why the negotiation with Pyongyang failed, therefore, it is imperative to examine the role the Congress had performed in the negotiation with the North, and the role the different types of government - the unified government and the divided government - had played in U.S. foreign policy making toward the North. In this regard, the two-level game model and the theory of political survival have significant implications, which will be delineated in more detail in the chapters IV and V.

The government types during the Clinton and Bush administrations can be classified into four different stages: united government under the presidency of Clinton (1993-1994), divided government under the presidency of Clinton (1995-2000), united government under the presidency of Bush (2001-2006), and divided government under the presidency of Bush (2007-2008). Although this dissertation deals with all four stages, it focuses more on the period of the divided government under the Clinton presidency from 1995 through 2000 and the period of the unified government under the Bush presidency from 2001 through 2006, because it clearly represent how different government types resulted in different U.S. policies toward North Korea. 
We must clarify the definition of 'divided government,' since there are two separate uses of the term. The first refers to "the absence of simultaneous same-party majorities in the executive and legislative branches of government" (Elgie, 2001, 2). In this sense, the concept is understood in an arithmetic sense, and especially valid for the United States with a two-party system. The second usage concerns a certain type of political behavior: "Divided government corresponds to the situation where there is conflict between the executive and legislative branches of government" (Elgie, 2001, 7). In this sense, divided government can occur even when there is unified government in an arithmetical sense. However, there are problems with adopting the behavioral interpretation of the term. Most notably, it makes the criteria for identifying the various periods of unified government and divided government far more subjective. Thus, the following discussion adopts the arithmetical definition of divided government as a situation where: "the executive fails to enjoy majority support in at least one working house of legislature" (Elgie, 2001, 11).

Table 1 shows 4 differently categorized types of the U.S. government between 1993 and 2008 according to the arithmetic definition of divided government. 
Table 1. The Types of the U.S. Government, 1993-2008

\begin{tabular}{|c|c|}
\hline United Government & Divided Government \\
\hline \hline Democratic President/ & Democratic President/ \\
Democratic Congress & Republican Congress \\
$(1993-1994)$ & $(1995-2000)$ \\
\hline Republican President/ & Republican President/ \\
Republican Congress & Democratic Congress \\
$(2001-2006)$ & $(2007-2008)$ \\
\hline
\end{tabular}

Note: The Senate of the $107^{\text {th }}$ Congress (2001-2002) started with Republicans in control with Vice President Dick Cheney's tie-breaking vote under the even split of 50 Republicans and 50 Democrats. The defection of Senator James M. Jeffords (R-VT) turned the control of the Senate over to the Democrats with 50 Democrats, 49 Republicans, and one independent. As a result of the 2002 midterm elections, however, Republicans recaptured the Senate.

The hypothesized relationship between government type and the United States' North Korea policy during the Clinton and Bush administrations can now be stated more formally, as follows:

Hypothesis \#1: A divided U.S. government produces more status quo policies toward North Korea than a unified U.S. government.

It is expected that because of partisan politics, a President in a divided government is hard-pressed to get strong support from Congress when taking more aggressive policies or more conciliatory policies. Conversely, in a unified government, 
Congressional support is available for a more adventurous foreign policy, should the President embrace one.

Partisan politics or partisanship, in this dissertation, is defined as political behavior of members of Congress "as motivated to protect or advance the collective interests of their party organizations" (Lee, 2009, 24). "It rests, fundamentally, on partisans' widespread and willing cooperation in pursuit of collective goals and on the inherent zero-sum conflicts between the two parties' political interests as they seek to win elections and wield political power" (Lee, 2009, 18). Political opposition stems not only from different individual ideologies, but also for collective party interests. ${ }^{16}$

Hypothesis \#2: A unified U.S. government with a Democratic President produces more conciliatory policies toward North Korea, whereas a unified U.S. government with a Republican President produces more aggressive policies toward North Korea.

It is expected that because of partisan politics, a Democratic President in a unified government finds it easier to get strong support from Congress when advocating more conciliatory policies. This is also a matter of party ideology. And for the same reasons, a Republican President in a unified government will find it easier to get strong support from Congress when taking an aggressive stand.

Thus, the main argument of this dissertation can be summarized as follows:

\footnotetext{
${ }^{16}$ See Carl Schmitt (2007) for a philosophical discussion on the origins of partisan politics based on the "friend-enemy" distinction.
} 
Different Government Types + Party Politics $=$ Different Policy Choices (or Policy Inconsistency)

Table 2 shows the relations between U.S. government types — divided government and unified government — and the hypothesized outcomes of United States' North Korea policy during the Clinton administration (1993-2000) and the Bush administration (20012008).

Table 2. The Government Types and North Korea Policy Outcomes, 1993-2008

\begin{tabular}{|c|c|c|}
\hline Gresidency & United & Divided \\
\hline Republican & $\begin{array}{c}\text { Aggressive Confrontation/ } \\
\text { Deadlock }\end{array}$ & $\begin{array}{c}\text { Status Quo/ } \\
\text { Passive Engagement }\end{array}$ \\
\hline Democratic & $\begin{array}{c}\text { Conciliatory Engagement/ } \\
\text { Negotiated Settlement }\end{array}$ & $\begin{array}{c}\text { Status Quo/ } \\
\text { Crisis Management }\end{array}$ \\
\hline
\end{tabular}

Chapter III outlines the structural foundations and the historical trends of the rivalry and power struggle between the presidency and the Congress in U.S. foreign policy making. To make sense of the role and influence of the different government types on U.S. North Korea policy during the Clinton and Bush administrations, it is essential to study the interbranch power struggle in the area of American foreign policy both structurally and historically. This chapter consists of two sections. The first section of the Chapter III outlines the constitutional and institutional foundations of U.S. foreign policy. 
The second section looks at a historical overview of divided government in the United States. This chapter will show that Congress constitutionally has a variety of means to exert influence on U.S. foreign policy. It will also show that divided government has historically had a great impact on U.S. foreign policy.

Chapter IV examines the role of different types of the U.S. government in the United States' North Korea policy making during the Clinton administration (1993-2000). It is comprised of two sections: the Clinton Administration under unified government (1993-1994) and the Clinton Administration under Divided Government (1995-2000). This chapter will show that Clinton's North Korea policy changed from conciliation to status quo because of changes of different government types. While Clinton embraced a more appeasing policy toward Pyongyang under a unified government in 1993-1994, he adopted a status quo policy under a divided government in 1995-2000.

Chapter V examines the role of different types of the U.S. government for North Korea policy making during the Bush administration (2001-2008). It is also comprised of two sections: the Bush administration under unified government (2001-2006), and the Bush Administration under divided government (2007-2008). This chapter will show that Bush's North Korea policy changed from an aggressive one to a status quo policy as the government type changed . Bush espoused a more hostile policy toward Pyongyang under a unified government in 2001-2006, while he accepted a status quo policy under a divided government in 2007-2008.

Chapter VI concludes that the different government types during the Clinton and Bush administrations did make significant differences with regard to the U.S. policy choices and outcomes toward North Korea. It also concludes that a divided U.S. 
government produced more status quo policies toward North Korea than a unified U.S. government. Finally, it argues that a unified U.S. government with a Republican President produced more aggressive policies toward North Korea, while a unified U.S. government with a Democratic President produced more conciliatory policies.

\subsection{Conclusion}

Institutional factors are crucial to make sense of U.S. foreign policy because they affect policy makers irrespective of social or individual factors. Different institutional settings respond differently to foreign affairs. In U.S. foreign policy, one of the most notable institutional settings is different government types, unified government and divided government. The power struggle between Congress and the presidency is most evident in divided governments, and different government types produce different foreign policies. Partisan politics have dramatically increased since the Vietnam War and particularly since the end of the Cold War. This study seeks to contribute to the existing literature by providing a hard case study by confirming the consequential role of different government types and partisanship on U.S. North Korea policy. 


\section{FOREIGN POLICY AND AMERICAN POLITICS}

If you ask most Americans who makes foreign policy in the United States, they will answer it is the president. And to a point they are right. Foreign policy decisions are often made by a small number of individuals. Abraham Lincoln once told his cabinet, "Gentlemen, the vote is 11 to 1 , and the 1 has it (as cited in Hermann, Preston, Korany, \& Shaw, 2001, 84). Harry S. Truman even went so far as to say, "I make American foreign policy" (as cited in Wittkopf \& McCormick, 2008, 277). Because presidential power on foreign policy looks preeminent, it is tempting to think of foreign policy as determined exclusively by president and his executive branch officials. But this is not the case. According to the U.S. Constitution, powers over foreign policy are shared between the presidency and the Congress. ${ }^{17}$

\subsection{The Constitutional and Institutional Foundation of U.S. Foreign Policy}

Henkin (1996), in his classic book, Foreign Affairs and the US Constitution, argued, "the foreign relations of the United States cannot be understood without that law [the US Constitution], for it continues to shape the institutions and the actions that determine those relations" (4). The American Constitution broadly defines the distribution of power in the government of the United States and provides the primary foundation for understanding legislative-executive interbranch relations in the making of

\footnotetext{
${ }^{17}$ On the role of the third major branch of government in the United States, the judiciary, in foreign affairs, see Henkin, 1996, 131-148.
} 
foreign policy. While Article I of the Constitution enumerates the powers of the legislative branch (general legislative power in the Congress), Article II enumerates the powers of the president (the general executive power). Article I states that Congress shall "provide for the common Defense and general Welfare ... regulate commerce with foreign nations ... define and punish piracies and felonies ... declare wars ... and make rules ... [and] provide for calling forth the militia to execute the laws of the Union, suppress insurrections, and repel invasions." Furthermore, key diplomatic powers of the president are subject to the advice and consent of the Senate. Finally, Congress shall have the power "to make all laws which shall be necessary and proper for carrying into execution the foregoing powers, and all other powers vested by this Constitution in the government of the United States, or in any department or officer thereof (Rosati \& Scott, 2007, 307-08)."18

Article II states, on the other hand, that the president as "commander in chief of the army and navy of the United States, and of the militia of the several States ... shall have power, by and with the advice and consent of the Senate, to make treaties, provided two-thirds of the Senators present concur; and he shall nominate, and by and with the advice and consent of the Senate, shall appoint ambassadors, other public ministers and consuls." The president also "shall receive ambassadors and other public ministers; he shall take care that the laws be faithfully executed, and shall commission all the officers

\footnotetext{
${ }^{18}$ For more detailed explanations on congressional power on foreign affairs, see Henkin, 1996, 63-82. For a variety of formal or informal tools the Congress has used since the end of the Cold War, see Carter, 1998, $110-116$.
} 
of the United States." Finally, the president has the power to veto legislation (Rosati \& Scott, 2007, 307). ${ }^{19}$

In sum, the Constitution distributes power between the legislative and executive branches and clearly delineates a balanced interbranch relationship between the president and the Congress in U.S. foreign policy making. ${ }^{20}$ But many important foreign policy matters fall in "twilight zone," where the president and Congress have concurrent authority or the distribution of power is uncertain. The two branches are, to quote Neustadt (1990), "separated institutions sharing power" (29). The form of their partnership, the balance of institutional interests and prerogatives, therefore, is still subject to constant competition and negotiation in the practice of U.S. foreign policy making (Mann, 1990, 5-6), especially when democracy requires a strong Congress, while security requires a strong President (Nogee, 1981, 199). ${ }^{21}$

Neustadt, Rosati \& Scott (2007) also argue that it is a mistake to "understand the distribution of power between Congress and the president as a 'separation of powers,' for the Constitution did not create separate institutions with separate powers but separate

\footnotetext{
${ }^{19}$ For more detailed explanations on presidential power on foreign affairs, see Henkin, 1996, 31-62.

${ }^{20}$ Even if the conventional wisdom sees the president and the executive branch as a dominant actor in the making of U.S. foreign policy, the question of which branch the framers of the Constitution really wanted to be more preeminent in foreign policy is still subject to discuss. While, for example, Louis Fischer (2007: 8) maintains that "at the national level, [the framers of the American Constitution] vested greater powers in an executive... the inefficiency of the Continental Congress convinced the framers of the need for a separate and independent executive, Mann (1990) claims that "the Constitution favors Congress, the first branch of government" (4). Koh (1990) holds that the Constitution "expressly divided foreign affairs powers among the three branches of government, with Congress, not the president, being granted the dominant role (emphasis original, 75)," and Rosati \& Scott (2007) argue that "the founders intended and expected that the legislature be the preeminent branch in the government" (308). Morgenthau (1993), meanwhile, argues that "the American government is the outstanding modern example of a governmental system whose stability is maintained by an equilibrium among its component parts" (186).

${ }^{21}$ For more detailed explanations on concurrent authority between the president and the Congress, see Henkin, 1996, 83-130. For presidential power on foreign affairs after the Cold War, see Rosati \& Twing, 1998, 29-56.
} 
institutions sharing power - which is what is meant by 'checks and balances.",22 They state:

While the Congress provides military funding and declares war, the president is the commander in chief. Congress may pass bills, but the president may veto them, and Congress may then override the veto. The president is able to make treaties and appointments, but the Senate must provide its advice and consent. As students of the Constitution such as Edwin Corwin have indicated, the result was an invitation to struggle, which has fostered recurring conflicts between Congress and the president in the making of foreign policy throughout American history (308).

While the Constitution delineates a number of important powers for the legislature, the way Congress influences foreign policy is more complex than the roles enumerated in the document. In fact, members of Congress have a wide variety of options to exert an influence on foreign policy. We should distinguish between two dimensions of power, giving rise to four congressional avenues of influence. First, Congressional power can be either legislative or non-legislative. Legislative actions involve formal congressional activities such as passing laws, approving treaties, and authorizing and appropriating funds, while non-legislative actions include congressional activities not

\footnotetext{
${ }^{22}$ Fisher (2007), however, argues, "The separation doctrine ... still retains vitality" (13). For more details on the question of "separation of power" vs. "sharing of power", see Fisher, 2007, 1-20.
} 
related to specific legislative documents. ${ }^{23}$ Second, there are both direct and indirect powers as well. Members of Congress may take direct action targeting specific foreign policy issues, or they may take indirect action, taking aim at the broader context, process, or policy climate to signal preferences or condition policy (Rosati \& Scott, 2007, 311-12).

Table 3 presents diverse congressional paths to exert an influence on foreign policy.

Table 3. Congressional Paths to Foreign Policy Influence

\begin{tabular}{|c||c|c|}
\hline Path & Direct & Indirect \\
\hline \hline \multirow{4}{*}{ Legislative } & $(1)$ & $(3)$ \\
& Issue-Specific Legislation & Non-Binding Legislation \\
& Treaties (Senate) & Appointments (Senate) \\
& War Power & \\
& Appropriations & \\
& Foreign Commerce & $(4)$ \\
& Informal Advice/Letters & Framing Opinion \\
& Consultations & Foreign Contacts \\
& Oversight/Hearings & \\
\hline Non-Legislative & Use of Courts & \\
& &
\end{tabular}

SOURCE: Adapted from J. M. Scott, "In the loop: Congressional Influence in American Foreign Policy." Journal of Political and Military Sociology, 25 (Summer 1997): 61.

The first cell in table 3 includes the most obvious powers available to members of Congress: direct-legislative paths. These paths include powers to declare war, to pass

${ }^{23}$ See also Burgin, 1997, 296-302. 
substantive legislation, to appropriate funds, and to regulate international commerce. The Senate also has the power to approve treaties. The second cell shows direct-nonlegislative paths available for members of Congress to affect policy through consultations and various communications with the president and other administration officials by holding hearings, issuing reports on specific issues, and even bringing lawsuits against the president or administration. The third cell shows indirect-legislative paths: the use of formal legislative powers that are not targeted at particular issues, but rather signal preferences or condition the policy process or environment by appointing administration personnel, creating institutions of foreign policy (like the creation of the Department of Homeland Security), establishing policymaking procedures and reporting requirements, and taking other actions that affect the participants and processes of decision. The last cell presents indirect-non-legislative paths that are neither legislative nor issue-specific. In these approaches, members of Congress typically reach outside of the government to attempt to "change the climate of opinion surrounding the policy," by relying on public activities and events for the media exposure or by having direct meetings with foreign officials. Through these various paths, members of Congress shape foreign policy in a number of ways (Rosati \& Scott, 2007, 311-13).

To understand congressional activity, influence, and legislative-executive relations in U.S. foreign policy, however, it is also crucial to examine four general areas in more detail: (1) the war powers, (2) advice and consent, (3) the power to appropriate funds and to make laws, and (4) the power of oversight and investigation. The war powers have been the most important factor for the growth of presidential power. Although Congress has the constitutional authority to declare war, it has done so just five 
times in American history, while presidents have committed military forces abroad in over two hundred instances. The president's war power has grown remarkably over time, particularly during times of conflict (Rosati \& Scott, 2007, 328).

From 1789 to 1950, all major military activities by the United States were decided by Congress, either by a formal declaration of war or by a statute authorizing the president to use military force. Since then, however, the situation has changed dramatically. Presidents over the past half century have increasingly acted in a unilateral way when using military force against other countries without any approval or consent from Congress. Instead of seeking congressional authority, presidents justify military actions either on the commander in chief or based on decisions by the UN Security Council and the North Atlantic Treaty Organization (Fisher, 2008, 169).

There have been substantial efforts from Congress to redress the historical growth of presidential war power, one of which is The War Powers Act (WPA). The WPA represented a major symbolic effort aiming at congressional restoration and reassertion on the issue of use of force abroad, but it has not fundamentally limited the presidential war power. Since 1973, despite the WPA, the president has continued to use U.S. forces abroad in numerous situations, not least because members of Congress have still been extremely cautious in challenging presidential war power (Rosati \& Scott, 2007, 328-31). Louis Fisher (2008) argues that this concession by Congress on presidential war power does not only "weaken Congress and the power of the purse", it also "undermines public control, the system of checks and balances, and constitutional government” (183).

The Senate has the constitutional authority to advise the president on and consent to his appointments and treaties, and this gives members of Congress opportunities to 
shape foreign policy by exerting influences over personnel. In deference to presidential leadership, international agreements and commitments are usually ratified or approved with bipartisan support. Treaties have been "routinely passed by overwhelming majorities" (Meernik, 1993, 579). Between the end of World War I and the end of the Cold War, the Senate only rejected three treaties (Wittkopf, Kegley, \& Scott, 2003, 412).

Among international agreements made since World War II, furthermore, most were executive agreements - not requiring Senatorial advice and consent. By the end of the century, more than 90 percent of the international agreements of the United States were in the form of executive agreements. In response, Congress has used four methods in an effort to restore and reassert its advice-and-consent authority in the agreementmaking process: laws forcing the president to provide it with basic information when agreements are signed, laws forcing the president to submit executive agreements to the Senate as treaties, the power of the purse withholding funds necessary to implement executive agreements, and the power to approve or disapprove executive agreements ${ }^{24}$ (Rosati \& Scott, 2007, 331-335).

Although Congress has not been very effective either in wielding its war power or in exercising its advise-and-consent authority, its budgetary and legislative powers have been a strength of members of Congress in the foreign policy making process. Congressional budgetary power or spending power provides regular opportunities for influence, since presidents cannot do what is not funded. A good illustration of this fiscal power is foreign assistance. A good example is the decision of Congress to end all U.S.

\footnotetext{
24 The power to approve or disapprove executive agreements has had limited success because of the likelihood that such requirements are unconstitutional (Rosati \& Scott, 2007, 334).
} 
military assistance to South Vietnam and Cambodia in February 1975, which accelerated the end of the Vietnam War in April of that year (Rosati \& Scott, 2007, 335-336). ${ }^{25}$ Congressional legislative or law-making power provides big opportunities for authority, since Congress can directly make laws which it thinks are necessary to engage in foreign policy issues. The War Powers Act in 1973 is a good example of law-making power of Congress (Rosati \& Scott, 2007, 335-337).

Finally, Congress also has the power to oversee and investigate foreign affairs. With respect to legislative oversight in foreign policy, three main approaches can be identified: (1) regular oversight, (2) event-driven oversight, and (3) crisis-driven oversight. Together, these may result in proactive supervision of the executive branch or in a more reactive crisis-driven approach. Two additional characteristics of oversight are also noteworthy: (1) reporting requirements and (2) special commissions to conduct investigations. Reporting requirements are a congressional instrument that promotes oversight. Such requirements are a very effective way to extract information from the executive branch, because they obtain information through both regular reports and special reports. So-called "blue-ribbon" commissions, generally drawn from key experts and former policy-makers from both political parties can be another efficient way to oversee and investigate the foreign policy issues conducted by the president and the executive branch. A good illustration of congressional oversight and investigation powers was the Iran-Contra hearings and subsequent report by a joint congressional committee (Rosati \& Scott, 2007, 337-341).

\footnotetext{
${ }^{25}$ For more examples of congressional fiscal power, see Rosati \& Scott, 2007, 336.
} 


\subsection{A Historical Overview of Divided Government}

Because foreign policy is made and implemented by "the actions officials take on behalf of the nation," government structures considerably influence the "conduct and content of foreign affairs" (Wittkopf \& McCormick, 2008 141). In U.S. politics, one of the most influential government structures that affect foreign affairs is divided government. Divided government in U.S. politics has occurred about two-thirds of the time since 1945 . Now they seem to be the norm rather than the exception. But divided governments are nothing new in American history. There were many instances of divided governments throughout the history, and they can be traced back to as early as 1820 s. One of the most obvious characteristics of interbranch relations between the Presidency and the Congress has been the cyclical pattern of power over U.S. domestic and foreign policy. Throughout American history, the pendulum of power has fluctuated, swinging back and forth between Congress and the president (Hamilton, 2006). To understand how divided governments have practically affected U.S. foreign policy, it is necessary to examine the historical pattern between the presidency and the Congress on foreign policy and the history of divided government.

The Historical Pattern between the Presidency and the Congress on Foreign Policy

Thurber (2006) traces the causes of the historical pendulum swing between the president and Congress to the structural setting of American politics (7-20). According to Thurber (2006), the root causes of the cyclical pendulum swing or permanent rivalry 
between the president and Congress lie in "the constitutional design with its formal presidential and congressional powers; different electoral constituencies for the president, the House, and the Senate; varying terms of office; increased partisanship and polarization of Congress; the ongoing competition for power between Congress and the president; the permanent election campaign; narrow majorities in both houses; congressional individualism, the impact of the media in the twenty-four-hour, sevendays-a-week news cycle; and the nature of interest groups and American pluralism" (7). Therefore, "intense rivalry between the president and Congress is inevitable in an electoral system that can produce divided party control of the two branches (emphasis added, 21).

Lindsay (2008), on the other hand, attributes interbranch rivalry to political environments rather than the structure of U.S. politics. According to him, the reason for these ebbs and flows does not lie in the Constitution, but in politics. Perceptions of threat and presidential success in foreign policy have been the two most important factors affecting Congressional behavior. When Americans feel secure, Congress becomes aggressive. In comparison, when Americans feel threatened, Congress becomes deferential. When presidential policies are seen to be successful, presidents can push Congress to the sidelines, while struggling presidents are severely challenged by Congress. In sum, in times of national emergency, crisis, or war, power tends to flow toward the president, while in times of peace, power tends to flow back to Congress. Put another way, while times of crisis favor congressional acquiescence and deference, times 
of peace favor congressional activism and assertiveness (200). ${ }^{26}$ Rosati \& Scott (2007)

also state:

With the end of war and national emergency, the conditions that gave rise to the expansion of presidential power disappear. Periods of normalcy or relative stability result in congressional reassertion of power. Hence, the president experiences greater constraints on his ability to exercise power in foreign policy. Such cutbacks occurred after all of the major wars, but most noticeably following World War I, when the Senate rejected the Treaty of Versailles and the League of Nations. Also, during the interwar years, Congress passed legislation that increasingly affected the conduct of U.S. foreign policy and constrained presidential power, culminating in the neutrality legislation that tied the hands of President Franklin Roosevelt as World War II approached (313).

In the second half of the nineteenth century, the United States was as secure from outside threat at any time in American history. This was a time of congressional domination in its foreign policy issue areas, so that it has been called the era of

\footnotetext{
${ }^{26}$ Rosati \& Scott (2007) acknowledge that "the distribution of foreign policymaking power between Congress and the president has fluctuated, sometimes dramatically, with changes in the political environment" (313), but they have a different view than Lindsay on the accumulation of presidential power in foreign policy. While Lindsay emphasize a kind of pendulum (or cyclical) effect, Rosati \& Scott (2007) argue, "Yet the increase in presidential power during periods of conflict tend to be so extensive that the balance seldom returns to prewar levels, so presidents have accumulated greater power overtime" (313).... "Thus, times of war and national emergency are likely to be times of presidential preeminence, while times of peace are likely to result not in congressional ascendance but in political struggles between the legislative and executive branches over foreign policy" (emphasis original, 314). Rosati \& Twing (1998) also claim that "while Congress tends to reassert its constitutional authority and power following war, increases in presidential power during periods of conflict tend to be so extensive that it seldom returns to prewar levels. Thus, the cyclical ebb and flow in executive-legislative relations in foreign policy has enabled a president to accumulate greater power over time" (31).
} 
"congressional government," "congressional supremacy," "government-by-Congress," and "senatorial domination" (Lindsay, 1994, 15). Between 1871 and 1898, the Senate did not approve major treaty, with the partisan votes. In the presence of U.S. victory in the Spanish-American War, "the soon-to-be secretary of state John Hay wrote that he 'did not believe another important treaty would ever pass the Senate' and that 'the man who makes the Treaty of Peace with Spain will be lucky if he escapes a lynching"' (as cited in Lindsay, 2003, 15).

When the United States engaged in World War I, the pendulum of power began to shift to the president. Woodrow Wilson was not challenged by Congress many times during his presidency. But once the war ended, Congress challenged and fought the president, reasserting itself in U.S. foreign policy decision making. A good example is the rejections of the League of Nations by Congress. Congressional activism persisted and even intensified into the 1930s. Franklin Roosevelt suffered attacks from an aggressive Congress before Japan's bombing of Pearl Harbor. World War II saved him from the assertive congressional challenge, and Roosevelt expanded his power on foreign policy (Lindsay, 2008, 203).

Growing concerns about the threat of the Soviet Union and the expansion of communist countries after World War II forced the Congress to be deferential to strong presidential leadership. This congressional deference finally led to what Arthur Schlesinger called the "imperial presidency" in the 1960s (Schlesinger, 1973). Yet the era of "imperial presidency," the domination of presidential leadership on foreign policy, again gave way to congressional reassertion with the Vietnam War. With the public more willing to question administration foreign policy, and convinced that the Vietnam War 
and communist revolutions in the Third World posed no direct threat to core U.S. security interests, members of Congress were free to reassert control. In the 1970s and 1980s, “presidents Carter and Reagan did not get the acquiescence from Capitol Hill that Presidents Eisenhower and Kennedy did" (Lindsay, 2008, 204).

The end of the Cold War accelerated and exacerbated the congressional activism and assertiveness that Vietnam triggered. The collapse of the Soviet Union dramatically reduced the perception of threat of communism. According to Scott \& Crothers (1998), the post-Cold War era has had the following consequences for U.S. foreign policy making:

1. The ambiguity in the threat-interest-cost equation intensifies the tendency in the American public toward ambivalence (or reluctance) concerning international involvement.

2. Expanding globalization, interdependence, and transnationalism have raised the stakes for domestic interests, making foreign policy making more like domestic policy making - subject to conflict, bargaining, and persuasion among competing groups within and outside the government - in part due to the increasingly important link between domestic interests and international events, which has given risen to the expansion of "intermestic" issues.

3. Agenda change (from traditional security to economic and others) has expanded the elements of the bureaucracy with foreign policy concerns (especially the "economic complex") and increased the scope of the intermestic arena (thereby promoting more activity by Congress and nongovernmental actors), 
making both White House management (of the bureaucracy) and leadership (of policy) more difficult.

4. The lack of consensus makes policy leadership by any element of the U.S. government more difficult, and encourages elements of many parts of the government to press for their policy preferences (emphasis original, 19).

Since the end of the Cold War, as a result, congressional aggressiveness increased, while its deference decreased just as in the post-Vietnam period. In addition, the increase in intermestic issues and the decline in public consensus on foreign policy issues have offered "greater incentive and opportunity for members of Congress to be less deferential and more assertive in the post-Cold War era" and "led to greater congressional challenges to presidential leadership on a variety of issues" (Rosati \& Scott, 2007, 325). Clinton had to witness his four major international agreements - the comprehensive test ban, land mines, global warming, and international criminal court agreements - to become victims of congressional assertiveness and ideological partisanship (Rosati \&Scott, 2007, 326).

After the September 11 terrorist attacks, however, foreign policy again became a top priority with the public. The impact of September 11 on American public opinion was dramatic as the public started to feel less secure and more threatened by events outside America's borders. Bush's public approval ratings soared to 90 percent. Congress also immediately rallied behind presidential leadership in the name of state emergency and national security. Three days after the terrorist attack, Congress granted the president open-ended authority to retaliate against those who are responsible for it. The pendulum of power between the president and the Congress again swung back toward White House. 
In 2002, furthermore, Congress voted to authorize President Bush to wage war in Iraq. The resolution also meant authorizing a war against any country even before the United States had been attacked, in the name of preemptive action, which President Bush publicly announced in the 2002 National Security Strategy of the United States of America (Lindsay, 2008, 206-208).

History of Divided Government

Divided government has occurred about two-thirds of the time since 1945-just over six out of every ten years. Before the 1990s, Republican presidents faced a Democratic Congress. Republican presidents won five of six elections from 1968 to 1988, while the Democrats had permanent control of the Congress with majorities in one or both houses from 1955 to 1995. From 1995 to 2001, however, a Democratic president faced a Republican Congress (LeLoup \& Shull, 2003, 8; Conley, 2003, 3). Table 4 shows the cases of divided government since 1825 . 
Table 4. Divided Government since 1825

\begin{tabular}{|c|c|c|c|c|}
\hline President & Party & Congress & House Control & Senate Control \\
\hline Adams & $\mathrm{NR}^{*}$ & $20^{\text {th }}(1827-1829)$ & Jackson & Jackson \\
\hline Jackson & $\mathrm{D}$ & $23^{\mathrm{rd}}(1833-1835)$ & $\mathrm{D}$ & Opposition \\
\hline Tyler & $\mathrm{NP} * *$ & $28^{\text {th }}(1843-1845)$ & $\mathrm{D}$ & W \\
\hline Polk & $\mathrm{D}$ & $30^{\text {th }}(1847-1849)$ & $\mathrm{W}$ & $\mathrm{D}$ \\
\hline Taylor & W & $31^{\text {st }}(1849-1851)$ & $\mathrm{D}$ & $\mathrm{D}$ \\
\hline Fillmore & W & $32^{\text {nd }}(1851-1853)$ & $\mathrm{D}$ & $\mathrm{D}$ \\
\hline Pierce & $\mathrm{D}$ & $34^{\text {th }}(1855-1857)$ & $\mathrm{R}$ & $\mathrm{D}$ \\
\hline Buchanan & $\mathrm{D}$ & $36^{\text {th }}(1859-1861)$ & $\mathrm{R}$ & $\mathrm{D}$ \\
\hline Grant & $\mathrm{R}$ & $44^{\text {th }}(1875-1877)$ & $\mathrm{D}$ & $\mathrm{R}$ \\
\hline Hayes & $\mathrm{R}$ & $45^{\text {th }}(1877-1879)$ & $\mathrm{D}$ & $\mathrm{D}$ \\
\hline Hayes & $\mathrm{R}$ & $46^{\text {th }}(1879-1881)$ & $\mathrm{D}$ & $\mathrm{D}$ \\
\hline Arthur & $\mathrm{R}$ & $48^{\text {th }}(1883-1885)$ & $\mathrm{D}$ & $\mathrm{R}$ \\
\hline Cleveland & $\mathrm{D}$ & $49^{\text {th }}(1885-1887)$ & $\mathrm{D}$ & $\mathrm{R}$ \\
\hline Cleveland & $\mathrm{D}$ & $50^{\text {th }}(1887-1889)$ & $\mathrm{D}$ & $\mathrm{R}$ \\
\hline Harrison & $\mathrm{R}$ & $52^{\text {nd }}(1891-1893)$ & $\mathrm{D}$ & $\mathrm{R}$ \\
\hline Cleveland & $\mathrm{D}$ & $54^{\text {th }}(1895-1897)$ & $\mathrm{R}$ & $\mathrm{R}$ \\
\hline Taft & $\mathrm{R}$ & $62^{\text {nd }}(1911-1913)$ & D & $\mathrm{R}$ \\
\hline Wilson & $\mathrm{D}$ & $66^{\text {th }}(1919-1921)$ & $\mathrm{R}$ & $\mathrm{R}$ \\
\hline Hoover & $\mathrm{R}$ & $72^{\text {nd }}(1931-1933)$ & $\mathrm{D}$ & $\mathrm{R}$ \\
\hline Truman & $\mathrm{D}$ & $80^{\text {th }}(1947-1949)$ & $\mathrm{R}$ & $\mathrm{R}$ \\
\hline Eisenhower & $\mathrm{R}$ & $84^{\text {th }}(1955-1957)$ & $\mathrm{D}$ & $\mathrm{D}$ \\
\hline Eisenhower & $\mathrm{R}$ & $85^{\text {th }}(1957-1959)$ & $\mathrm{D}$ & $\mathrm{D}$ \\
\hline Eisenhower & $\mathrm{R}$ & $86^{\text {th }}(1959-1961)$ & $\mathrm{D}$ & $\mathrm{D}$ \\
\hline Nixon & $\mathrm{R}$ & $91^{\text {st }}(1969-1971)$ & $\mathrm{D}$ & $\mathrm{D}$ \\
\hline Nixon & $\mathrm{R}$ & $92^{\text {nd }}(1971-1973)$ & $\mathrm{D}$ & $\mathrm{D}$ \\
\hline Nixon & $\mathrm{R}$ & $93^{\text {rd }}(1973-1974)$ & $\mathrm{D}$ & $\mathrm{D}$ \\
\hline Ford & $\mathrm{R}$ & $93^{\mathrm{rd}}(1974-1975)$ & $\mathrm{D}$ & $\mathrm{D}$ \\
\hline Ford & $\mathrm{R}$ & $94^{\text {th }}(1975-1977)$ & $\mathrm{D}$ & $\mathrm{D}$ \\
\hline Reagan & $\mathrm{R}$ & $97^{\text {th }}(1981-1983)$ & $\mathrm{D}$ & $\mathrm{R}$ \\
\hline Reagan & $\mathrm{R}$ & $98^{\text {th }}(1983-1985)$ & $\mathrm{D}$ & $\mathrm{R}$ \\
\hline Reagan & $\mathrm{R}$ & $99^{\text {th }}(1985-1987)$ & $\mathrm{D}$ & $\mathrm{R}$ \\
\hline Reagan & $\mathrm{R}$ & $100^{\text {th }}(1987-1989)$ & $\mathrm{D}$ & $\mathrm{D}$ \\
\hline Bush & $\mathrm{R}$ & $101^{\text {st }}(1989-1991)$ & $\mathrm{D}$ & $\mathrm{D}$ \\
\hline Bush & $\mathrm{R}$ & $102^{\text {nd }}(1991-1993)$ & $\mathrm{D}$ & $\mathrm{D}$ \\
\hline Clinton & $\mathrm{D}$ & $104^{\text {th }}(1995-1997)$ & $\mathrm{R}$ & $\mathrm{R}$ \\
\hline Clinton & $\mathrm{D}$ & $105^{\text {th }}(1997-1999)$ & $\mathrm{R}$ & $\mathrm{R}$ \\
\hline Clinton & $\mathrm{D}$ & $106^{\text {th }}(1999-2001)$ & $\mathrm{R}$ & $\mathrm{R}$ \\
\hline Bush & $\mathrm{R}$ & $107^{\text {th }}(2001-2003)$ & $\mathrm{R}$ & $\mathrm{D} * * *$ \\
\hline Bush & $\mathrm{R}$ & $109^{\text {th }}(2005-2007)$ & $\mathrm{D}$ & $\mathrm{D}$ \\
\hline
\end{tabular}


Note: This table shows history of divided government since 1825 , because a comprehensive national two-party system developed in the mid-1820s. Legend: $\mathrm{D}=$ Democrat, $\mathrm{NP}=$ No Party Affiliation, $\mathrm{NR}=$ National Republican Party, $\mathrm{R}=$ Republican, $\mathrm{W}=$ Whig

* President Tyler was a former Democrat who ran for Vice President on Whig ticket. He was expelled in 1841 by the Whig party after clashing with Whig congressional leaders.

**Although the Senate was tied 50-50 after the 2000 election, when Senator James Jeffords of Vermont left the Republican party in June, 2001, the Senate came under Democratic control.

SOURCE: Adapted from J. H. Silbey. (1996) "Divided Government in Historical Perspective, 1789-1996.” In P. F. Galderisi, R. Q. Herzberg, \& P. McNamara, eds. Divided Government: Change, Uncertainty, and the Constitutional Order. Lanham: Rowman \& Littlefield: 12, and L. T. LeLoup \& S. A. Shull. (2003) The President and Congress: Collaboration and Combat in National Policymaking, second edition. New York: Longman: 9. Figures on $109^{\text {th }}$ Congress supplied by author.

Divided government becomes more common after 1945 and endemic since the 1968 election. While divided government prevailed only 14 percent of the time (for six years) from 1901 to 1944 , it prevailed 33 percent of the time (for eight years) from 1945 to 1968 . From 1969 to 2002 , divided government increased to almost 75 percent of the time - for twenty-eight years of the past thirty-eight years (Rosati \& Scott, 2007, 342). ${ }^{27}$

Divided government, of course, is nothing new in American history. In fact, there were many instances of divided governments throughout American history since its very

\footnotetext{
${ }^{27}$ For detailed party control of the presidency and congress in the twentieth century from 1901 to 2007 , see the table 11. 3 in Rosati \& Scott, 2007, 343.
} 
inception. Young \& Riley (1990) argued that "even during the one-party "Era of Good Feeling," when presidential candidates were nominated by the congressional caucus, government was effectively divided" (as cited in Fiorina, 1996a, 6). Some instances of divided government occurred when both houses of Congress were in the hands of a party other than the one that controlled the presidency, while others meant only that the presidency and one house were in different partisan hands. Some happened at the outset of a presidential administration, while others resulted from midterm elections to Congress. In the nineteenth century, however, divided governments were mostly created by midterm elections. Of the sixteen instances, for example, only three occurred in the first years of an administration, while the others occurred in the latter half of a president's term (Silbey, 1996, 10-13).

For analytic purposes, drawing on the work of Silbey (1996) and DeLaet \& Scott (2006), we can categorize the whole American political history into four phases in terms of divided government. The fourth phase can further be divided into three periods. Table 5 presents the four phases of divided government in American political history. 
Table 5. Phases of Divided Government in American History

\begin{tabular}{|c|c|c|c|}
\hline \multicolumn{2}{|c|}{ Phase } & Presidency & Year \\
\hline \multicolumn{2}{|c|}{$\begin{array}{c}\mathrm{I} \\
\text { The Primitive Phase }\end{array}$} & Jackson - Tyler & $1827-1849$ \\
\hline \multicolumn{2}{|c|}{$\begin{array}{c}\text { II } \\
\text { The Party Phase }\end{array}$} & Polk - the second Cleveland & $1849-1897$ \\
\hline \multicolumn{2}{|c|}{$\begin{array}{c}\text { III } \\
\text { The Progressive Phase }\end{array}$} & Taft - Hoover & $1911-1933$ \\
\hline \multirow{3}{*}{$\begin{array}{c}\text { IV } \\
\text { The } \\
\text { Modern } \\
\text { Phase }\end{array}$} & $\begin{array}{c}\text { I } \\
\text { Cold War }\end{array}$ & Truman - Eisenhower & $1947-1961$ \\
\hline & $\begin{array}{c}\text { II } \\
\text { Post-Vietnam } \\
\end{array}$ & Nixon - Reagan & 1969-1989 \\
\hline & $\begin{array}{c}\text { III } \\
\text { Post-Cold War } \\
\end{array}$ & Bush Sr. - Bush Jr. & $1989-2009$ \\
\hline
\end{tabular}

Silbey (1996) separated the premodern eras of divided government—from 1827 to 1949 — into three phases. Phase I (1827-1845) includes the cases of Adams, Jackson, and Tyler, where "the primitive and undeveloped state of the political parties resulted in a great deal of disarray on the political landscape" (14). Phase I was characterized by "an intense policy deadlock... and... the kind of image of divided government that has been presented in much of the scholarly literature" (16). Phase II (1847-1897) comprises the eleven cases in the rest of the nineteenth century, from Polk to the second Cleveland administration. The second phase shows "the power of the partisan structure that had emerged to dominate American politics. It was characterized by the full formation and acceptance of national political parties with quite marked policy differences between them. The idea of legitimate opposition, compromise, and the working out of matters through negotiation all became accepted political norms” (17). Each Phase II 
administration entailed "a familiar variety of experiences associated with divided government: much conflict between Congress and the president over policy matters and personnel, the failure of legislative initiatives, and, in most cases, the ultimate wearing down of an already tired administration in the latter half of its life course. Each contained, as well, a range of situations unique to its particular moment in time. Finally, in each case, the party holding the presidency lost the next election" (17).

Divided government was a constant reality in America even before pre-Civil War era, and became more commonplace after the Civil War. No president between 1875 and 1895 enjoyed having his own party in control of both houses of Congress for his full term in office (Silbey, 1996, 19). The Phase II cases, therefore, were contextually different from those of both earlier and later eras, in the sense that "the whole period was dominated by political players who had strong and quite polarized policy views but who, unlike those in Phase I, acknowledged and accommodated their differences" (Silbey, 1996, 21).

Phase III (1911-1933) includes the final three cases in the premodern period of the American political experience, Taft, Wilson, and Hoover, and is distinguished from Phase II in a number of important ways. According to Silbey (1996):

In Phase III, the first half of the twentieth century, political parties were beginning... to lose their command of the nations' political process... but they still retained much of their sting. This changing partisan condition was coupled with the great expansion of the functions and powers of the federal government, and of the potential for sharp policy differences, that we associate with 
Progressivism and the New Deal. The authority of the president expanded as the issues of industrialization and economic adjustment moved beyond the capacity of existing institutions... In Phase III, elections were much less competitive than they had been earlier. One or the other major party dominated the races in successive blocs of years. All of these factors made the possibility of divided government much rarer than it had been in Phase II. In fact, in Phase III, divided government did become much less common than it had ever been on the American scene and, therefore, more noticeable when it did occur (21).

From the 1820 s to the 1890 s, divided government was something more persistent than any other periods in its existence in American political history. It is important, however, to note that "the incidents of divided government... vary significantly in their nature and situation. They occurred on different political terrains with different defining and shaping elements at play in each phase" (Silbey, 1996, 23). In fact, the more we consider the whole of American history, the clearer it becomes that much about the current situation of divided government is mislabeled just because "divided government has been, essentially, a time-bound phenomenon, limited in reach and applicability, and not a particularly appropriate description of the situation we have in our own time" (Silbey, 1996, 24).

Phase IV includes three distinct periods with varying patterns of congressional foreign policy behavior: a Cold War period, a post-Vietnam period, and a post-Cold War period. For much of the early post-World War II period, Congress was more deferential to presidential leadership on a variety of foreign policy issues, and presidential leadership 
became more salient. After examining the voting records of Republicans and Democrats in Congress from 1945 to 1948, Dahl (1950) concluded that "the record of bipartisan proposals between 1945 and 1948 is an excellent one” (228). Holsti \& Rosenau (1984) and Destler, Gelb, \& Lake (1984) also argued that for the two decades following World War II, bipartisan consensus on a wide range of foreign policy issues did indeed exist. Finally, in his classic article “The Two Presidencies,” Wildavsky (1966) argued:

The United States has one president, but it has two presidencies; one presidency is for domestic affairs, and the other is concerned with defense and foreign policy. Since World War II, presidents have had much greater success in controlling the nation's defense and foreign policies than in dominating its domestic policies... The president's normal problem with domestic policy is to get congressional support for the programs he prefers. In foreign affairs, in contrast, he can almost always get support for policies that he believes will protect the nation (reprinted in Shull, 1991, 11).

During the pre-Vietnam Cold War period, members of Congress "were presumed to set aside political concerns and address foreign policy issues in a more bipartisan fashion than domestic policy" (DeLaet \& Scott, 2006, 180). Since the Vietnam War, however, presidential leadership "has come under increasing scrutiny and members of Congress have become more assertive," as "the Cold War consensus unraveled and dissatisfaction with Cold War policies increased" (DeLaet \& Scott, 2006, 181). Members of Congress no longer trusted presidential leadership in foreign affairs after the disastrous 
policy failure in Vietnam. Deeping globalization and its consequential increase of intermestic issues also played an important role in the revival of congressional activism and assertiveness. Finally, members of Congress acquired greater resources for dealing with foreign affairs, including increased staff (DeLaet \& Scott, 1996, 181).

Wildavsky's two-presidencies thesis, therefore, turned out not to be valid after the Vietnam War period. The thesis was reconsidered, restricted, or even rejected later by many studies including one by Wildavsky himself. A significant body of research examining the gap between domestic and foreign success of presidencies shows that there has been a decline in the gap since 1970s, particularly presented by "a breakdown of the bipartisan consensus after Vietnam and Watergate, reforms in Congress that expanded information sources available to members and reduced the president's informational advantage, and reforms in Congress that altered the types of issues that get to the floor for a vote" (Fleisher et al, 2000, 6). Destler, Gelb, \& Lake (1984) and Brzezinski (1984) also pointed out the demise of bipartisanship since the Vietnam War. Wildavsky himself, in a study with Duane M. Oldfield, noted that "various studies cast serious doubt on the conclusions of "the two presidencies" outside of the period in which the thesis was proposed. Only Dwight Eisenhower was clearly more successful in foreign policy... If we look at key foreign policy votes from the Eisenhower through the Carter administrations, we find that a majority of the opposition party supported only Eisenhower more than half the time..." Therefore, "the two presidencies" is time and culture bound (Oldfield \& Wildavsky, 1991, 182-83).

In the meantime, numerous studies have found changes in congressional foreign policy behavior after the end of the Cold War. While congressional challenges to 
presidential leadership on foreign policy have dramatically increased, bipartisan support for presidential leadership has considerably decreased. In the post Cold-War period, intermestic issues and increasing constituency pressures have led to all these changes from congressional acquiescence and deference to legislative activism and assertiveness. In addition, the risk of challenging presidential leadership diminished, both because of more benign international environment and because of a decline in public interest in foreign affairs issues after the end of the Cold War (DeLaet \& Scott, 2006, 181-182).

Admittedly, the September 11 terrorist attacks considerably reversed this extensive trend of congressional activism and assertiveness since Vietnam. The preeminent presidency was revived.$^{28}$ However, "how far such congressional deference extended beyond national security issues after $9 / 11$ is another matter. Congress was willing to challenge President Bush on other issues like trade policy, and it made restrictions on civil liberties in the USA Patriot Act temporary, not permanent... Moreover, increasing congressional assertiveness after 2003 strongly suggests that legislative deference was a temporary response, soon replaced by the more confrontational pattern of the previous three decades" (Carter \& Scott, 2010, Web).

\subsection{Conclusion}

This chapter examined the structural foundations and the historical trends of the interbranch relationship between the presidency and Congress in order to see how

\footnotetext{
${ }^{28}$ For criticisms on congressional acquiescence and deference to the presidency, see Wolfensberger, 2002; Ornstein \& Mann, 2006; Ohaegbulam, 2007; Fisher, 2008; Hansen \& Friedman, 2009.
} 
Congress legally influences U.S. foreign policy and how the different government types have traditionally affected U.S. foreign policy. Constitutionally, Congress has a variety of means to exert influence on U.S. foreign policy. For this reason, in part, divided government has historically had a great impact on U.S. foreign policy.

The U.S. Constitution distributes power between the legislative and executive branches and stipulates a balanced relationship between the president and Congress in U.S. foreign policy making. Still, many important foreign policy matters fall in a "twilight zone," and the result is "an invitation to struggle." Divided government makes this problem more complicated. Furthermore, divided government in U.S. politics has occurred about two-thirds of the time since 1945. It has become so common that it seems to be the norm rather than the exception. Divided governments, however, are nothing new in American history. There were many instances of divided governments throughout the history and these divided governments have always had a great impact on U.S. foreign policy. Nevertheless, one of the most obvious characteristics of interbranch relations in the United States has been the cyclical pattern of power. The pendulum of power has fluctuated throughout the American history. 


\section{THE PRESIDENCY, THE CONGRESS, AND U.S. POLICY TOWARD NORTH KOREA DURING THE CLINTON ADMINISTRATION}

President William J. Clinton was in office in 1993-2000. In 1993-4, President Clinton embraced a more conciliatory policy toward North Korea under a unified government and tried to solve the North Korea nuclear problem by negotiation, notably through the 1994 Geneva Agreed Framework with Pyongyang. In 1995-2000, however, President Clinton adopted a status quo policy toward North Korea under a divided government, failing to take further steps to improve U.S.-North Korean relations and to conclude the denuclearization of North Korea. To understand why President Clinton took up two different policy approaches toward North Korea, this chapter examines the interbranch relationship between the presidency and Congress, its impact on the U.S. policymaking toward Pyongyang, and the policy outcomes on the North Korea nuclear issue from 1993 through 2000.

4.1. The Clinton Administration under unified government (1993-1994)

In 1993-4, President Clinton was in a strong position to pursue a conciliatory policy toward North Korea because, as Putnam (1988) might put it, Clinton could expand the win-set with strong support from Congress in negotiating with Pyongyang on its nuclear issue. That is to say, at the time, Clinton had some room for maneuver with both Congress and North Korea. This finally led to a negotiated settlement of the first nuclear crisis with the conclusion of the Geneva Agreement in 1994. 
4.1.1. U.S. Policy toward North Korea during the Clinton Administration (1993-1994)

The first crisis between the United States and North Korea over the North Korean nuclear program began not long before the Clinton administration in 1989, when the CIA reportedly obtained evidence proving North Korea's capability of developing nuclear weapons on its own. However, the crisis did not escalate until 1993-4, when Pyongyang threatened that it would withdraw from the NPT, decided to pull the fuel rods from a reactor, and announced its withdrawal from the IAEA. As both sides prepared for a possible war, former President Jimmy Carter visited Pyongyang and brokered a deal with Kim Il Sung that defused the crisis by freezing activities at Yongbyon in exchange for the resumption of negotiations between the United States and North Korea.

President William J. Clinton took office when the United States had become a triumphant world leader, or "lonely superpower," without a true hegemonic rival since the end of the Cold War. The collapse of the Soviet Union and the subsequent demise of the communist system particularly in East Europe provided the United States a new opportunity and responsibility to reconstruct the international order. The U.S. preeminence was not only military, but also ideological, political, economic, and cultural (Brooks \& Wohlforth, 2002; Ikenberry, 2002; Kapstein \& Mastanduno, 1999; Nye, 2002).

In the Asia-Pacific region, however, the historical legacy of the Cold War remained. Communist regimes such as China, North Korea, and Vietnam were still confrontational and standoffish with American political and military regional allies, including Japan, South Korea, and Taiwan. On the Korean peninsula, in particular, 
"expectations for North-South reconciliation and cooperation were overshadowed by escalating tensions and mistrust between Seoul and Pyongyang. Hence the new Clinton administration was saddled with a complicated and seemingly contradictory mixture of global and regional trends in the strategic, diplomatic, and economic fields" (Lee, 2006, 159).

Under these regional political circumstances, when Clinton took office in the early 1990s, he thought that new security threats to the United States and its allies would be caused mainly by evil dictators, international terrorists, and transnational criminal organizations, and by the local armed conflicts that could destabilize the peace of entire regions. In addition, the incoming secretary of defense, Les Aspin, also thought that regional threats to U.S. interests from Korea, Iraq, and Africa would replace the former Soviet Union as the major focus of U.S. foreign and defensive policy. The Clinton administration, in addition, expressed its determined commitment to stopping the spread of nuclear weapons and other weapons of mass destruction, to strengthening the International Atomic Energy Agency (IAEA), and to implementing strong diplomatic and economic sanctions against governments violating international agreements. The new secretary of state, Warren Christopher said, "One of the main security problems of this era will be the proliferation of very deadly weapons - nuclear, chemical, biological, and enhanced conventional weapons - as well as their delivery systems... We must work assiduously with other nations to discourage proliferation through improved intelligence, export controls, incentives, sanctions, and even force when necessary" (as cited in Lee, 2006, 159-60). 
The first challenge to these foreign policy principles came from North Korea when it rejected the request by the IAEA for special inspections of suspected nuclear facilities at Yongbyon in 1993. Pyongyang announced on March 12, 1993, that it would withdraw from the NPT after the required waiting period of three months. In response, the Clinton administration decided not to use military force against North Korea but to seek a diplomatic solution through the IAEA and the United Nations. This policy toward Pyongyang signified the modification of the traditional U.S. policy of military containment and diplomatic isolation toward North Korea during the Cold War. The new Clinton administration, instead, decided to pursue a policy of constructive engagement with North Korea for the purpose of discouraging nuclear proliferation. This new diplomatic gesture from Clinton was based partly on the classic liberal assumption that even with dictatorial countries such as North Korea, sincere negotiations could be conducted and reasonable agreements could be reached in good faith. ${ }^{29}$ But its implementation would have not been possible without support from the Democratic majority in Congress.

On April 1, the IAEA Board of Governors declared that North Korea was not in compliance with its obligations under its nuclear safeguards agreements with the IAEA and demanded North Korea to comply with the IAEA request for a special inspection to verify that North Korea was not producing nuclear weapons. Pyongyang rejected the IAEA's demand on the grounds that it impinged upon the principle of state sovereignty and was designed to probe North Korea's military bases and facilities. As a result, the

\footnotetext{
${ }^{29}$ Feffer (2003) characterizes Clinton's North Korea policy as "congagement" policy which is a hybrid of containment and engagement (96).
} 
UN Security Council issued a statement on April 8 expressing concern about Pyongyang's provocative behavior. On May 11, the UNSC adopted a resolution requesting that North Korea reaffirm its commitment to the NPT, honor its nonproliferation obligations under the treaty, and comply with its safeguards agreement with the IAEA.

Pursuant to a request from Pyongyang, the first round of talks between the United States and North Korea started in New York on June 2. The talks achieved a surprisingly dramatic breakthrough and resulted in a joint statement on June 11, a day before the North Korea's withdrawal from NPT was to become effective. On July 14, the United States and North Korea held a second round of talks in Geneva, and in this meeting, the United States promised to facilitate construction of light-water moderated reactors (LWRs), which North Korea wanted in return for its graphite-moderated reactors. The United States rejected the North Korea demand, however, to stop the annual joint military exercises between the United States and South Korea. The two parties agreed to have a third round of talks in Geneva in September 1993, but this meeting was never held, largely because of North Korea's refusal to permit IAEA inspections.

On October 1, the IAEA General Conference adopted a resolution against North Korea, urging it to cooperate immediately with the IAEA. A month later, on November 1, the UN General Assembly also passed a resolution against North Korea. Pyongyang simply ignored both resolutions, and criticized the IAEA for being under the control of the United States. On November 23, 1993, Clinton announced that he would take "a thorough, broad approach" toward North Korea to resolve North Korean nuclear issues, which was another expression of "a comprehensive approach" or "package deal" (Lee, 
2006, 167). Despite Clinton's hinted willingness to negotiate with Pyongyang, however, the situation was continuously aggravated by other developments. On March 21, 1994, the IAEA Board of Governors passed a resolution to urge North Korea to comply with its safeguards agreement and to refer the issue to the Security Council and the General Assembly of the United Nations.

On March 31, the UNSC issued a presidential statement demanding that North Korea allow IAEA inspections. The North denounced the statement as containing "unjustifiable demands," and threatened to regard any sanctions resolution at the UNSC as a declaration of war requiring it to take appropriate action (Lee, 2006, 169). Meanwhile, the Clinton administration started to intensify diplomatic pressure on North Korea through international organizations such as the United Nations. At the UNSC, the United States drafted a resolution to impose economic and diplomatic sanctions against North Korea. Pyongyang, in response, threatened to wage war rather than yield to international condemnation and economic pressure. With the escalation of tension between the United States and North Korea, the Korean Peninsula stood on the brink of another major war.

Under these circumstances, former U.S. President Jimmy Carter was dispatched to Pyongyang on June 15. Although Carter characterized his visit as a "private mission," had a significant symbolic meaning since it was the very first visit of a former president of the United States to North Korea. ${ }^{30}$ In a meeting with Kim Il Sung, Cater obtained an

\footnotetext{
${ }^{30}$ On August 4, 2009, former president Bill Clinton also paid a visit to Pyongyang to secure the release of two American journalists who had been detained, convicted, and sentenced by the North Korean government for illegally entering North Korea. Clinton's visit marks the second visit of a former president of the United States to North Korea. Interestingly enough, Clinton also identified his visit as a private mission.
} 
agreement that North Korea would freeze the nuclear program in exchange for a U.S. security commitment and the provision of LWRs. President Clinton viewed Carter's visit as "an escape hatch, some way to climb down without losing face" for Kim Il Sung (as cited in Lee, 2006, 173). In the meeting, Kim Il Sung also agreed to an inter-Korean summit meeting, which was to be held in Pyongyang on July 25 through 27. The Clinton administration, as a consequence, suspended its sanctions efforts at the United Nations, halted further military deployments, and opened a third round of talks in Geneva on July 8. On the very next day, however, the sudden death of Kim Il Sung ended the meeting, as the North Korea delegation was obliged to leave for Pyongyang to attend the funeral. Clinton expressed his sincere condolences, while Kim Young Sam, the president of South Korea, refused to do so, but rather criticized the late Kim's legacy. Kim Jong Il, the son of Kim Il Sung and his successor, was enraged and announced that he would not have a meeting with Kim Young Sam.

On August 12, North Korea and the United States reached a provisional "Agreed Statement." The agreement was possible because "while Clinton was eager for this agreement so that he could publicize the success of his foreign policy prior to the midterm congressional elections in November-especially in view of the questionable record of his policies in Somalia, Haiti, and Bosnia—Kim Jong Il embraced his father's legacy and sought to demonstrate the positive consequences of his political succession" (Lee, 2006, 175). After a series of meetings to finalize the agreement, on October 21, 1994, the United States and North Korea signed the Agreed Framework in Geneva, Switzerland. By signing the Agreed Framework, North Korea earned $\$ 4.5$ billion worth of potential economic assistance in return for freezing its nuclear program. The Agreed 
Framework also allowed North Korea to have an opportunity to break out of its international isolation, to normalize diplomatic relations with the United States and other countries, and to join key international organizations. Furthermore, Pyongyang received a guarantee from Washington that the United States would not use or threaten to use nuclear weapons against North Korea as long as Pyongyang abided by the agreement. In retrospect, "The Agreed Framework was a major turning point not only for the interests of nuclear nonproliferation on the Korean Peninsula but also for the expansion of official contracts between the United States and North Korea" (Lee, 2006, 179). The agreement also enhanced Clinton's status in domestic and foreign affairs. Satisfied with the agreement, Clinton said, "This agreement will help to achieve a long-standing and vital American objective — and end to the threat of nuclear proliferation on the Korean Peninsula... It reduces the danger of the threat of nuclear weapons spreading in the region" (as cited in Lee, 2006, 179). Warren Christopher also said that "the Agreed Framework stands out as one of the major achievements of our foreign policy... This was an occasion on which the United States rose to the challenge of its indispensable leadership role" (as cited in Lee, 2006, 179). However, Clinton's gambit for a negotiated settlement with North Korea that finally resulted in the conclusion of the Geneva Agreement would not have been possible without the strong support of the Democratic majority in Congress. 


\subsubsection{Presidency vs. Congress: Overview}

To make sense of the role and the impact of the power struggle between presidency and Congress in 1993-4, it is instructive to briefly consider the history of the interbranch relationship and the increase of partisan politics at this time. In 1993, Congress was exceptionally productive in its lawmaking, particularly because, with the new Democratic president, "Congress acted on a broad range of issues that had been frozen for 12 years in partisan cross-fire between a Democratic Congress and a Republican White House" (1993 CQ Almanac, 3). Under the new unified Democratic government, thus, democratic policies, programs, and agendas "flowed freely down the legislative sluice for the first time in more than a decade" (1993 CQ Almanac, 3). ${ }^{31}$ The year 1993 was marked particularly by two controversial measures: a deficit-reduction "reconciliation" bill passed in August and the North American Free Trade Agreement (NAFTA) approved in November. While both were huge political triumphs for Clinton, other laws did not require so much political capital to enact, because the Democratic majority in Congress easily approved a number of bills that had cleared in previous years but had been vetoed.

Despite the inclination and desire of Clinton and Democratic members of Congress to focus on domestic policy, however, the worsening situations in Somalia, Bosnia, and Haiti continuously demanded attention from both the president and Congress.

\footnotetext{
${ }^{31}$ During the first session of the $103^{\text {rd }}$ Congress, there were 6,721 bills and resolutions introduced, compared with 4,258 in 1992. A total of 210 bills cleared by the $103^{\text {rd }}$ Congress became public laws. President Clinton signed 208 of them. President George H. W. Bush signed the first two before leaving office on Jan. 20. During 1993, the House took 615 roll call votes and quorum calls, 227 more than in the previous year. The Senate took 395 roll call votes, 125 more than in 1992 (1993, CQ Almanac, 8).
} 
This forced Congress to re-evaluate its relationship with the president on foreign policy. Although Congress and the president struggled over their relative powers and responsibilities, Congress was more cooperative with Clinton than it had been with Bush Senior. Nevertheless, it was impossible to realize all of Clinton's wishes, and partisan politics in Congress was still alive. For example, "when Clinton initiated a tough deficit reduction package in 1993, not a single Republican in the House and Senate voted for it" (LeLoup \& Shull, 2003, 3). "Lots of things got blocked," according to David Mayhew, "It's not as if there is a free flow down the highway of everything you put on a truck" (as cited in 1993 CQ Almanac, 4).

Among Clinton's biggest defeats in Congress were the loss of construction and social service programs proposed to stimulate the economy, which were blocked in April 1993 in the Senate, and his efforts to end the prohibition against gays serving in the military, which he had to drop because of the strong bipartisan opposition from both chambers of the Congress. Although Clinton had begun the year in a weak position as a president elected with a minority of the vote and had suffered through numerous mishaps, he finally ended the year with major victories on trade, budget policy, and gun control. In sum, in 1993, President Clinton still entertained strong support from Democratic majority Congress, despite partisan oppositions from the Republican Party.

The year 1994, however, brought Clinton major legislative setbacks and political fiascoes, including the failure of his top priority, the health care initiative. Clinton had trumpeted the proposal, as a test of his leadership and control in Congress, yet he never had sufficient votes to pass the proposal in either chamber. As a result, the devastating loss "sucked the wind out of Clinton's standing and elbowed out other legislative 
initiatives, including welfare reform" (1994 CQ Almanac, 3). Democratic members of Congress had started the second session with high hopes for their party. Because of the laws enacted on budget, trade and social policy during the first session, they were highly confident about remaking the health care system, welfare, political campaign laws, telecommunications policy, mining law and more. In addition, the economy was rebounding and approval ratings for Clinton were rising. ${ }^{32}$ It is no wonder that Clinton tried to capitalize on these expectations. He called on Congress to tackle three priorities: health care, welfare, and crime. However, none turned into a triumph for Clinton or for the Democratic leadership. Congress took no action on welfare. The crime bill was enacted in a spirit of rancor that bloodied Clinton and ended any lingering hope of passing a health care bill in 1994 .

As a result of continued partisan politics, "numerous measures, some of which began the year with broad bipartisan support, fell victim to partisan disagreement or other problems and had to be abandoned" (1994 CQ Almanac, 3), mainly because Republicans blocked Democratic legislative program at every turn with the increased confidence of their midterm election prospects. Many measures and initiatives had to be buried due primarily to procedural barriers built by Republicans who became confident in exploiting the technical gridlock. Before the end of the session, however, Clinton won a belated, but crucial bipartisan victory, approving a bill to implement a new global trade accord under the General Agreement on Tariffs and Trade (GATT). ${ }^{33}$ In sum, in 1994, although

\footnotetext{
${ }^{32}$ He went over 60 percent in a January NBC/Wall Street Journal poll (1994 CQ Almanac, 4).

${ }^{33}$ President Clinton became the first president since 1853 to not veto a single bill during an entire Congress. The last president to do so was Millard Fillmore, the nation's $13^{\text {th }}$ president, in the $32^{\text {nd }}$ Congress (1851-53). During the second session of the $103^{\text {rd }}$ Congress, there were 3,103 bills and resolutions introduced,
} 
Clinton was not as successful as in 1993 in his major reforms mainly because of partisan resistances, he still managed to gather enough support from the Democratic majority to win crucial victories at the end of the session.

\subsubsection{Presidency vs. Congress: North Korea}

During the critical period of crisis between the United States and North Korea over Pyongyang's nuclear ambition, President Clinton "was having an increasingly difficult time presenting himself as any kind of international leader" (Barilleaux \& Kim, 1999, 32-33). He "was not very much interested in active involvement in foreign policy, and he championed domestic matters during his presidential campaign. Clinton saw himself as a domestic president" (Barilleaux \& Kim, 1999, 29). The legislative priorities described in the preceding section make this clear. Furthermore, his Republican critics "focused on his indecisiveness, his endless flexibility, his lack of principle, and his willingness to tailor policy to domestic opinion polls" (Barilleaux \& Kim, 1999, 33).

President Clinton "had to convey a convincing portrait of world leadership and willingness to do what was necessary to avoid nuclear chaos (Barilleaux \& Kim, 1999, 33). On NBC's "Meet the Press" program on November 7, 1993, Clinton, whose engagement policy toward North Korea had come under harsh criticism from the Republican Party, categorically declared that any military attack on South Korea "is an attack on the United States" and warned if North Korea produced nuclear weapons and

compared with 6,721 in 1993 and 4,258 in 1992. A total of 465 bills cleared by the $103^{\text {rd }}$ Congress became public laws (210 in the first session). During 1994, the House took 507 roll call votes and quorum calls, 108 fewer than in the previous year. The Senate took 329 roll call votes, 66 fewer than in 1993 (1994 CQ Almanac: 5). 
used them against South Korea, the United States would mobilize its overwhelming military power to obliterate North Korea (as cited in Lee, 2006, 166). This rhetoric was intended not only to warn North Korea but also to quell criticism of his policy in South Korea and in the U.S. Congress. Despite his lack of foreign policy expertise, however, he continued to seek bipartisan support in the Congress for his North Korea policy.

Although Republican legislators agreed with the broad outlines of Clinton's policy on a nuclear-free North Korea, they took an even tougher stance against North Korea. In February 1994, the Senate passed the State Department authorization bill. During six days of debate on the bill, senators adopted amendments urging administration action on issues ranging from nuclear proliferation in North Korea to preferential trade status for China. John McCain (R-AZ) vehemently denounced Clinton's North Korea nuclear policy as insufficiently forceful. The amendment called on Clinton to seek an international consensus to isolate Pyongyang economically until it had halted its nuclear program. Charles S. Robb (D-VA) also urged Clinton to consider reintroducing tactical nuclear weapons in South Korea to pressure the North to live up to its nuclear treaty obligations (1994 CQ Almanac, 455).

In June 1994, when Clinton suggested going forward with the sanctions resolution, Senator John McCain (R-AZ) again argued that "sanctions should be backed by the explicit threat of air strikes against North Korea's nuclear material reprocessing facilities" (as cited in Barilleaux \& Kim, 1999). Describing in considerable detail how Pyongyang's nuclear program could be destroyed by U.S. military power, he further said, "to all those apologists for the Administration's appeasement policy who argue that we must refrain from responses that might provoke the North into launching a military attack, I ask one 
question: Would an attack be more or less likely after North Korea acquires a nuclear arsenal and after it has completed its production of ballistic missiles capable of delivering nuclear warheads to Tokyo? I think the answer is obvious" (as cited in Carpenter \& Bandow, 2004, 43-44). Senate minority leader Robert Dole (R-KS) also argued that the “military option must be kept open” (Carpenter \& Bandow, 2004, 45).

In July 1994, House and Senate conferees agreed to strip the Senate amendment prohibiting the United States from providing any aid to North Korea, but they included the North on the list of countries specifically barred from receiving aid appropriated under the fiscal 1995 foreign operations bill. Warren Christopher, Secretary of State, was opposed to the Senate decision and complained that it "could block activities that are crucial" in bringing Pyongyang into compliance with its international agreements (as cited in 1994 CQ Almanac, 511). In August 1994, an amendment unanimously passed the Senate making any U.S. aid to North Korea contingent on a presidential certification that North Korea had halted its nuclear weapons program and did not have any nuclear weapons.

In addition, the 1994 Foreign Relations Authorization Act reflected the depth of congressional concerns about North Korea's noncompliance with the IAEA safeguards agreement and inspections. The 1994 Act delineated "eighteen non-binding policy directives that included an emphasis on regional responsibility, the crucial role of China, and the potential use of sanctions as a punitive measure" (Lee \& Miles, 2006, 188). The act also recommended involving all regional countries in the confrontation with North Korea, stating that "the problem posed by North Korea's nuclear program is not a bilateral problem between the United States and North Korea, but a problem in which 
virtually the entire global community is united against North Korea" (Lee \& Miles, 2006, 188). If international cooperation failed, "the president should employ all unilateral means of leverage over North Korea, including, but not limited to, the prohibition of any transaction involving the commercial sale of any good or technology to North Korea. And If North Korea refused to cooperate with IAEA, the law called for the president to seek international consensus to isolate North Korea, including the imposition of sanctions" (Lee \& Miles, 2006, 188).

Before the conclusion of the 1994 Geneva Agreement, a group of Republican senators including Alfonse D’Amato (R-NY), Mitch McConnell (R-KY), Jesse Helms (R-NC), and Frank Murkowski (R-AK), sent a joint letter to the president to urge him to back away from the deal. In the letter, they warned that the agreement would only "paper over the crisis and delay its resolution" and questioned about "how to distinguish such a deal from U.S. submission to North Korean blackmail" (Carpenter \& Bandow, 2004, 47). Senator Robert Dole (R-KS) also complained that the deal "shows that it is always possible to get an agreement when you give enough away" (Carpenter \& Bandow, 2004, 47).

The 1994 deal was, in fact, called "the Agreed Framework" rather than "the Framework Agreement" to avoid the ratification issue (Cossa, 2003). In January 1995, with a new Republican majority Congress, Clinton declined the demands from the chairs of three Senate committees - Energy and Natural Resources, Foreign Relations, and Intelligence - that the agreement be redefined as a formal treaty, which would require the advice and consent of the Senate. Instead, the Clinton administration characterized the arrangement as an "Agreed Framework," which was less binding than a formal treaty. 
Had the Agreed Framework acquired a status of treaty, it might have paved the way for much better U.S.-North Korean relations in the last half of the decade. However, Clinton did not attempt to do so, mainly because he was afraid that the Senate would reject the agreement and force him to return to the bargaining table with Pyongyang. Indeed, many members of Congress criticized the negotiation process even before its conclusion.

In sum, even if Clinton faced partisan opposition and felt under pressure from the Republican legislators in both chambers of Congress, he exhibited presidential leadership in his dealings with North Korea under the Democratic unified government during 19931994. And even if he did not have overwhelming bipartisan support from both chambers of Congress for his North Korea policy, he managed to get enough support to negotiate with North Korea. Despite the partisan challenge from the Republican Party, however, there were no open efforts from Congress to nullify or modify the agreement during the period, in large part because both chambers were still controlled by the Democratic Party. Due to his support in Congress, President Clinton was able to pursue a more conciliatory policy toward North Korea.

\subsection{The Clinton Administration under Divided Government (1995-2000)}

In 1995-2000, in contrast with the preceding period, President Clinton adopted a status quo policy toward North Korea, failing to take further steps to improve U.S.-North Korean relations and to conclude the denuclearization of North Korea. He could not expand the win-sets necessary to end Pyongyang's nuclear ambition mainly due to opposition from the Republican majority in Congress. This section examines the 
interbranch relationship between presidency and Congress, its impact on the U.S. policymaking toward Pyongyang, and the policy outcomes on the North Korea nuclear issue from 1995 through 2000 .

4.2.1. U.S. Policy toward North Korea during the Clinton Administration (1995-2000)

On March 9, 1995, the Clinton administration signed the Agreement on the Establishment of the Korean Peninsula Development Organization (KEDO) along with South Korea and Japan to carry out the terms of the 1994 Agreed Framework. While the United States assumed major responsibility for the funds to supply heavy fuel oil to North Korea, South Korea and Japan also pledged to share a significant portion of the funds for the LWR projects. In September 1997, the European Atomic Energy Community in the European Union became a member of KEDO and joined on KEDO's executive board along with the United States, South Korea, and Japan. ${ }^{34}$

Although the Clinton administration was eager to open its liaison office in Pyongyang, and concluded a "Memorandum of Understanding" with North Korea in December 1994, this plan was never realized. In addition, the Clinton administration was hesitant to upgrade its fledging diplomatic relations with North Korea too quickly without commensurate improvement in inter-Korean relations because South Korea continued to insist on "linkages" and "parallelism" in this regard. Clinton achieved a big breakthrough, however, in economic relations with Pyongyang. The Clinton administration delivered 500,000 tons of heavy fuel oil to North Korea every year, facilitated the construction of

\footnotetext{
${ }^{34}$ For more detailed discussions on KEDO, see Quinones, 2007a.
} 
two LWRs in North Korea by a target date of 2003, and announced its initial measures to ease economic sanctions against North Korea on January 20, 1995.

On April 16, 1996, at a meeting with South Korea President, Kim Young Sam, Clinton proposed four-party talks including the United States, North Korea, South Korea, and China. This initiative was a significant departure from the earlier U.S. policy toward North Korea insisting that issues of peace and reunification must be resolved by the two Koreas. In turn, Pyongyang abandoned its earlier position that only the United States and North Korea were "the real parties" to the Armistice Agreement, and it agreed to join the four-party talks. The prospect of four-party talks was threatened by two unexpected events - a North Koran submarine incident in September 1996, and the defection of a senior North Korean leader, Hwang Chang Yop, in February 1997, but the first session was nevertheless held on December 9, in Geneva. Enthusiasm for the four-party talks began to dwindle in South Korea, however, because Seoul was greatly suffering from the Asian financial crisis. Pyongyang was not happy about the four-party talks either, because they did not directly discuss issues it considered critical such as the withdrawal of U.S. forces from South Korea and a peace agreement between the United States and North Korea. Despite Chinese enthusiasm, therefore, the four-party talks dissipated by the end of 1999.

Following the recommendations of the Perry report, Clinton invited North Korean Vice Marshal, Cho Myong Rok, to Washington in September 2000. This meeting resulted in the Joint U.S.-DPRK Statement and an invitation to Secretary of State Madeleine Albright to visit Pyongyang, a trip she took a few weeks later. At these and subsequent meetings, the two sides undertook discussions to eliminate North Korea's long-range 
ballistic missile program. ${ }^{35}$ The Clinton administration invited Kim Jong Il to come to Washington, but Kim rejected this invitation. North Korea instead wanted President Clinton to come to Pyongyang, but U.S. officials were reluctant to send the President without finishing the missile deal. In the end, neither trip took place.

No doubt Clinton hoped to reach a milestone in the search for lasting peace on the Korean Peninsula and in the Middle East, leaving a legacy of diplomatic triumph as his tenure drew to a close. In returning for lifting economic sanctions, he wanted North Korea to commit to a far-reaching agreement on America's major concerns - its nuclear and missile issues (Lee, 2006, 199). In 2000, the United States and North Korea put their cooperation on display by exchanging official visits. Jo Myong Rok, North Korean Vice Marshal, paid a visit to Washington in September 2000. In a joint communiqué issued on October 12, 2000, the two countries agreed to disavow any "hostile intent" against each other, to work to build mutual confidence, and to uphold the principles of respect for each other's sovereignty and noninterference in internal affairs. As a response, Madeleine Albright, U.S. Secretary of State, took a trip to Pyongyang a few weeks later in October. She was the highest-ranking member of the U.S. government ever to pay an official visit to North Korea (former president Jimmy Carter went in 1994 as a private citizen). At these and subsequent meetings, the two sides issued a joint U.S.-DPRK statement, and undertook discussions to eliminate North Korea's long-range ballistic missile program and stop exporting missiles to other countries.

A number of Republicans such as Senators Jesse Helms (R-NC) and Trent Lott (R-MS) also urged Clinton to defer any further decision on North Korean missiles to the

\footnotetext{
${ }^{35}$ For more details on the North Korean ballistic missile program, see Pinkston, 2008.
} 
incoming administration. The mass media was against Clinton's trip as well. The New York Times, for example, stated that "Clinton's visit would lend prestige to the North Korean leader, one of the world's last Stalinist dictators and a brazen violator of his people's human rights" (as cited in Lee, 2006, 207). Finally, the Bush foreign policy team was also against the trip. In an effort to salvage a U.S.-North Korean summit meeting, the Clinton administration invited Kim Jong Il to Washington, but Kim rejected this invitation. Clinton in the end had to urge the new Bush administration to continue his engagement policy toward North Korea. Clinton later told William Perry that it was his "biggest regret" that he did not visit Pyongyang.

Clinton's inaction and indecision resulted in large part from his experiences of struggling with the Republican Congress after 1995, experiences that significantly limited his initiative and ability for the North Korea policy. He came to realize that "a president who wants to take a new approach to some element of American foreign policy can be caught between the diplomat's desire for flexibility and the power of domestic political forces. The president can achieve success, but only if the new direction in policy finds acceptance on Capitol Hill” (Barilleaux \& Kim, 1999).

\subsubsection{Presidency vs. Congress: Overview}

The historic 1994 midterm congressional elections ended Democratic dominance in the Congress, brought divided party control of government back, and reshaped the rivalry between the president and Congress. The 1994 election not only brought an overwhelming victory for the Republican Party, but it also dramatically changed the 
balance of power between the president and Congress. Convinced that they had received an electoral mandate to implement their legislative program, Republican members of Congress confidently began dictating the policy agenda. In contrast, President Clinton found that his political power was significantly diminished after the 1994 election when the Republicans attempted to constrain the president's ability to influence Congress (Thurber, 2006, 3).

The midterm elections on Nov. 8, 1993 brought an end to nearly 40 years of Democratic control of the House. The voters gave control of both chambers to the Republicans for the first time since 1955. The elections swept out the House Speaker, Thomas S. Foley, D-Wash., along with legislative powerhouses such House Ways and Means Committee Chairman Dan Rostenkowski, D-Ill., while no Republican incumbent was defeated in the House or Senate. ${ }^{36}$

During the $104^{\text {th }}$ Congress in 1995 , the 88 bills enacted into law marked the lowest legislative output during a session since 1933, when the $20^{\text {th }}$ (or "Lame Duck") Amendment was ratified and the starting date of a Congress was moved from March to January. ${ }^{37}$ Both chambers were populated by a new cadre of lawmakers more intensely partisan than any other in contemporary times. "A large group of conservative freshmen, especially in the House, displayed remarkable ideological cohesion and became the most influential newcomers since fallout from the Watergate scandal swept reformist

\footnotetext{
${ }^{36}$ On opening day of the $104^{\text {th }}$ Congress, in the House, Republicans took majority control $-230-204$, with one independent - for the first time in 40 years. In the Senate, Republicans dominated, 53-47, for the first time since 1986 (1995 CQ Almanac, 1-3-4).

${ }^{37}$ The first session of the $73^{\text {rd }}$ Congress (the last to convene in March) enacted 93 bills into law, including much of President Franklin D. Roosevelt's New Deal legislation, in an abbreviated session lasting less than 100 days (1995 CQ Almanac, 1-5).
} 
Democrats into Congress in 1974" (1995 CQ Almanac, 1-3). As a consequence, Congress in 1995 became a more active and more partisan institution, and it was more ready and willing to defy the president than ever before in the post war period. ${ }^{38}$

The Republican majority in Congress brought the agenda-setting role from the White House to Congress, and Clinton had to contend with their new power and assertiveness. Congressional debate centered mostly on Republican issues including legislation designed to dismantle multiple layers of domestic programs, overturn regulations and attack the growth of entitlement such as Medicare and Medicaid. In other words, "Congress itself was transformed from a redoubt of liberalism into the nerve center of conservatism" (1995 CQ Almanac, 1-3). As a result, the bipartisan spirit quickly gave way to familiar partisan wrangling, as House Republicans began working to enact their legislative agenda, "Contract With America." ${ }^{, 39}$ A Congressional Quarterly survey at the 100-day mark of 33 votes on bills that incorporated the contract showed a high level of party unity. Of the class of 73 Republican freshmen, 53 voted with the party 100 percent of the time. Thirteen had a score of 97 percent; one, 95 percent; and four, 94 percent. In addition, a total of 141 of the 230 Republicans had scores of 100 percent (1995 CQ Almanac, 1-7).

Acknowledging that "I have made my mistakes," a politically weakened Clinton appealed for bipartisanship in his State of the Union address Jan. 24, 1995 and challenged

\footnotetext{
${ }^{38}$ In 1995 , the House took 885 roll call votes and quorum calls, 378 more than in the previous year. The Senate took 613 roll call votes, 284 more than in 1994 (1995 CQ Almanac, 1-5).

${ }^{39}$ The GOP's "Contract With America" was signed on Sep. 27, 1994, by more than 350 GOP incumbents and challengers assembled on Capitol Hill. It was a bold bid by Newt Gingrich to create a national platform for Republican candidates in the November 1994 elections. The contract gradually evolved into a holy writ that Speaker Gingrich used to foster discipline among House Republicans. For more detailed discussions on "Contract With America," see Bader, 1997.
} 
the Republican-controlled Congress to work with him toward a "leaner, not meaner" government (as cited in 1995 CQ Almanac, 1-5). However, the speech only provided clear evidence that Clinton no longer controlled the congressional agenda and knew it. Unlike his threat in 1994 to veto anything short of a comprehensive health care bill, Clinton's warnings in 1995 were delivered in a non-threatening way. In a sharp reversal, Clinton even had to endorse the idea of incremental health care legislation centered on insurance reforms.

The early success of several contract items in the House built momentum in the Congress. "Each step fed the next," said Representative Bill Paxon (R-NY) (1995 CQ Almanac, 1-6). Although Republican unanimity did not always come easily, the opposition of the Democrats often helped to unify Republican moderates and conservatives. ${ }^{40}$ Republican congressional leaders also mobilized outside support to give an added push to elements of the contract. For example, at the request of Majority Whip Tom DeLay (R-TX), a coalition known as "Project Relief" was set up by Bruce A. Gates, vice president of public affairs at the National American Wholesale Grocers' Association, to lobby for regulatory reform. They also worked to back the balanced budget amendment. Such various coalitions included the National Federation of Independent Business, National Taxpayers Union, Christian Coalition, National Association of Manufacturers, American Trucking Association, Americans for Tax Reform, and the U.S. Chamber of Commerce.

\footnotetext{
${ }^{40}$ In several cases, GOP leaders had to use what House Majority Leader Dick Armey (R-TX) called "friendly persuasion" to keep their troops in line (1995 CQ Almanac, 1-6).
} 
Overshadowed by their counterparts in the House, Republicans in the Senate also issued their own agendas from the beginning of the first session of the $104^{\text {th }}$ Congress. Signaling a slower, more deliberate pace, the Senate passed the first contract bill, on congressional compliance with workplace laws, Jan. 11. The pace reflected Senate rules, which allowed virtually limitless amendments. It also was, in part, a product of the role played by more senior GOP members, who did not share the House freshmen's enthusiasm for such planks as a middle-class tax cut and a balanced-budget amendment to the Constitution. Indeed, Senate Republicans had never endorsed the contract. Instead, they produced their own agenda, called "Seven More in '94," which included a balancedbudget amendment, national defense, crime, middle-class tax cuts, welfare reform and a relaxation of the earnings test for Social Security recipients.

Sometimes, Clinton used his veto power as a threat to influence the Republican Congress. ${ }^{41}$ More often, however, Clinton solicited cooperation from Congress. "I don't want to have a pile of vetoes," Clinton said at a Montana town meeting June 1. "So here I am - all dressed up and ready to cooperate.... I want to cooperate [with Congress], but it takes two to tango" (as cited in 1995 CQ Almanac, 1-8). Furthermore, Clinton did not win much help from his congressional Democrats in blunting the GOP agenda. Democrats were suffering problems transforming themselves into an effective opposition party, and there was little coordination with the White House.

In 1995, there were two government shutdowns as a result of a political standoff between Clinton and the Congress. The first shutdown came Nov. 14-19, when Congress

\footnotetext{
${ }^{41}$ Clinton had never used the veto power in his first two presidential years under the Democratic unified party control of government.
} 
had completed work on just five of the spending bills. The second closure began Dec. 16, when three spending bills were still stalled in Congress and three more had been vetoed. Republicans were surprised by the government shutdowns, because they underestimated Clinton's willingness to fight. Both sides ended the year with an unusually high level of animosity and partisan distrust. "This is the most polarized and embittered I've ever seen it," said Judiciary Committee Chairman Henry J. Hyde (R-Il), who had served in the House for 20 years (as cited in 1995 CQ Almanac, 1-11). ${ }^{42}$

However, confrontation gave way to compromise in the second session of the $104^{\text {th }}$ Congress in 1996 , as Republicans abandoned their earlier hard-charging tactics to achieve their legislative agendas due to the budget debacle in $1995 .{ }^{43}$ If the failed Republican shutdown strategy opened the door to a more compromising approach, the decision by Senate Majority Leader Bob Dole of Kansas to leave Congress in June to campaign full time for the GOP presidential nomination helped push the two parties the rest of the way. President Clinton also cooperated with the Republicans on a spate of legislation as he sought to become the first Democrat since Franklin D. Roosevelt to win a second term. By year's end, the temporary bipartisanship had worked well, and they shared victory. Republicans won the congressional election. They maintained control of the House, albeit by a narrower margin, and strengthened their majority in the Senate.

\footnotetext{
${ }^{42}$ The chief demand of Republicans on the balance of budget in seven years ended in humiliating defeat. The public blamed the Republicans for the government shutdowns and Clinton refused to concede. Finally, in January 1966, they agreed to reopen the government (1996 CQ Almanac, 1-3).

${ }^{43}$ Quantitatively, during the second session of the $104^{\text {th }}$ Congress, legislative productivity rate was relatively low, thanks in part to its early preoccupation with conservative legislation that stalled in the Senate. The $104^{\text {th }}$ Congress cleared 238 bills, compared with an average of 929 bills for the previous 10 Congresses. Qualitatively however, Congress took on difficult issues and managed to enact significant legislation where previous Congresses had failed (1996 CQ Almanac, 1-4).
} 
Clinton won the presidential election, scoring an overwhelming victory over Republican presidential nominee Bob Dole. ${ }^{44}$

Despite these successes on both sides of the aisle, partisan politics contributed to a large number of retirements. For example, retiring Representative Pete Geren (D-TX) said, "You have people on the far left and the far right who tend to have sharp differences of opinion, which leads to each party thinking the other is immoral or evil" (as cited in 1996 CQ Almanac, 1-4). However, the second session of the $104^{\text {th }}$ Congress in 1996 brought a decline in partisan politics, compared the first session in 1995. The GOP's "Contract With America" in the House of Representatives, which dominated the Republican political agenda in 1995, was replaced by the more soothing strategy of a "common sense agenda." In fact, it was rare in 1996 to hear of the contract from Republicans. Table 6 shows overall scorecard for the GOP's "Contract With America."

\footnotetext{
${ }^{44}$ There were a total of 2,759 bills and resolutions introduced in the session. Combined with the 5,231 introduced in the first session, the total of 7,990 bills and resolutions introduced in the $104^{\text {th }}$ Congress was 1,834 fewer than in the $103^{\text {rd }}$ Congress, when 9,824 were introduced. In all, 245 bills were signed into law in 1996, bringing the total number of measures enacted during the $104^{\text {th }}$ Congress to 333. President Clinton vetoed six bills during the second session, bringing the total number of vetoes in the $104^{\text {th }}$ Congress to 17; only one was overridden. During 1996, the House took 455 roll call votes and quorum calls, 430 less than in 1995 . The Senate took 306 roll call votes, 307 less than the previous year. Combined, however, the total of 2,259 roll call votes and quorum calls in the $104^{\text {th }}$ Congress was the highest since the $96^{\text {th }}$ Congress (1979-1980), when 2,304 were recorded. In 1996, the Senate broke its record for cloture votes taken in a single year. Senators voted 29 times on motions to end debate on a matter before the body, one more time than in 1992 (1996 CQ Almanac, 1-5; 1-7).
} 
Table 6. Contract With America Scorecard

\begin{tabular}{|c|c|c|c|c|c|c|}
\hline "Contract With America" Items & હ & 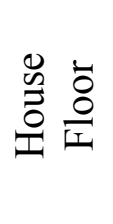 & 导 & 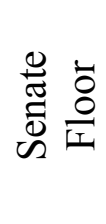 & 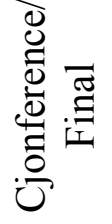 & 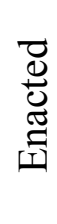 \\
\hline End Congressional Exemptions & & $\mathrm{O}$ & & $\mathrm{O}$ & $\mathrm{O}$ & $\mathrm{O}$ \\
\hline Revise House Rules & & $\mathrm{O}$ & & & & $\mathrm{O}$ \\
\hline Balanced-Budget Amendment & $\mathrm{O}$ & $\mathrm{O}$ & $\mathrm{O}$ & $\mathrm{S}$ & & \\
\hline Line-Item Veto & $\mathrm{O}$ & $\mathrm{O}$ & $\mathrm{O}$ & $\mathrm{O}$ & $\mathrm{O}$ & $\mathrm{O}$ \\
\hline Crime & $\mathrm{O}$ & $\mathrm{O}$ & $\mathrm{S}$ & $\mathrm{S}$ & $\mathrm{S}$ & $\mathrm{S}$ \\
\hline Welfare & $\mathrm{O}$ & $\mathrm{O}$ & $\mathrm{O}$ & $\mathrm{O}$ & $\mathrm{O}$ & $\mathrm{O}$ \\
\hline $\begin{array}{l}\text { Require Parental Consent for } \\
\text { Children Surveys }\end{array}$ & $\mathrm{O}$ & $\mathrm{O}$ & $\mathrm{O}$ & & & \\
\hline $\begin{array}{l}\text { Increase Penalties for Children Sex } \\
\text { Crimes }\end{array}$ & $\mathrm{O}$ & $\mathrm{O}$ & $\mathrm{O}$ & $\mathrm{O}$ & $\mathrm{O}$ & $\mathrm{O}$ \\
\hline Middle-Class Tax Cut & $\mathrm{O}$ & $\mathrm{O}$ & $\mathrm{O}$ & $\mathrm{O}$ & $\mathrm{O}$ & $\mathrm{S}$ \\
\hline National Security & $\mathrm{O}$ & $\mathrm{O}$ & & & & \\
\hline Social Security & $\mathrm{O}$ & $\mathrm{O}$ & $\mathrm{S}$ & $\mathrm{S}$ & $\mathrm{S}$ & $\mathrm{S}$ \\
\hline Capital Gains and Regulations & $\mathrm{O}$ & $\mathrm{O}$ & $\mathrm{O}$ & $\mathrm{O}$ & $\mathrm{O}$ & $\mathrm{S}$ \\
\hline Product Liability & $\mathrm{O}$ & $\mathrm{O}$ & $\mathrm{O}$ & $\mathrm{O}$ & $\mathrm{O}$ & $\mathrm{X}$ \\
\hline Term Limits & $\mathrm{O}$ & $\mathrm{X}$ & $\mathrm{O}$ & $\mathrm{X}$ & & \\
\hline
\end{tabular}

Note: $\mathrm{O}=$ Approved/Passed Substantially Intact, $\mathrm{X}=$ Defeated/Vetoed, $\mathrm{S}=$ Some Elements Approved/Passed/Enacted

SOURCE: Adapted from CQ Almanac (1996), 1-10.

In 1997, Republican congressional leaders worked to build bipartisan coalitions to pass bills. It seemed clear that divided government would force both sides to work with each other for at least the next two years and quite likely the next four, given the difficulty traditionally experienced by the president's party in off-year elections. This grudging cooperation set the tone for the $105^{\text {th }}$ Congress. Members of Congress looked more often for common ground with their adversaries rather than emphasizing different 
party lines. And controversial leaders such as House Speaker Newt Gingrich (R-GA) receded into the background. This new approach came to fruition when a bipartisan agreement was reached to balance the budget by 2002 while providing the biggest tax cut since the Reagan administration. Republican congressional leaders also got all 13 regular appropriations bills enacted, abandoning the take-it-or-leave-it strategy that had triggered two government shutdowns and hurt Republicans during their first two years in power. Beyond that, however, the first session of the $105^{\text {th }}$ Congress was not so productive. ${ }^{45}$

The first session of the $105^{\text {th }}$ Congress witnessed the GOP's priority items generally falling by the wayside. Social conservatives met with defeat on a number of socalled wedge issues. However, Clinton also lost on several issues consequential to his administrations. For instance, Congress refused to provide the money he requested to underwrite a world currency stabilization program and to pay off U.S. debts to the United Nations, after Clinton infuriated conservatives by blocking legislation to ban U.S. aid for overseas organizations that performed or advocated abortions. But Clinton's most important defeat was on renewal of fast-track authority to negotiate trade deals. ${ }^{46} \mathrm{Clinton}$ became the first American president who did not succeed in getting this authority that had always won bipartisan support from the Congress. ${ }^{47}$ Clinton also lost several

\footnotetext{
${ }^{45}$ During the first session of the $105^{\text {th }}$ Congress, 153 public laws were enacted. A total of 5,501 Bills/Resolutions were introduced. The number of recorded votes including quorum calls was 938 in total. The Senate held 24 cloture votes in 1997, slightly fewer than the 29 cloture votes in 1996 and more than the 21 votes in 1995 . Attempts to limit debate succeeded on seven occasions, each time by a wide margin. The closest thing to a squeaker was the 69-31 vote to proceed to consideration of the fast-track bill (S 1269) (1997 CQ Almanac, 1-4).

${ }^{46}$ For more detailed explanations on Clinton's failure in "fast-track" authority and CTBT, See Destler, 2001.

${ }^{47}$ None of his predecessors was without that authority for more than seven months since it was first granted Gerald Ford (Destler, 2001, 324).
} 
confirmation battles with the Senate. His nominees for ambassador to Mexico, assistant attorney general for civil rights, and surgeon general were all blocked.

Clinton learned to live with divided government. His first major public addresses in 1997 were "clearly intended to set a bipartisan tone and extend an olive branch to congressional Republicans" (1997 CQ Almanac, 1-5). He began his second term on Jan. 20 with an Inauguration Day address that was more somber than the one he had given four years earlier, when he stressed change and an energetic renewal. His speech seemed tempered by the political battles of his first term and by a keener understanding of the limits of the presidency and the government. In his State of the Union address on Feb. 4, Clinton said, "They want us to be partners, not partisans. They put us all here in the same boat, they gave us all oars and they told us row" (as cited in 1997 CQ Almanac, 1-6).

Despite Clinton's conciliatory gesture, however, stable bipartisanship was hard to achieve under divided government. President Clinton used or threatened to use the veto power when he thought it was necessary. Despite repeated veto threats, Republican congressional leaders in June tried to force the president to accept two controversial policy riders by attaching them to a must-pass disaster relief bill (HR 1469). The first provision would have guaranteed continued funding at existing levels to any agency whose regular appropriations bill had not become law by the Oct. 1 start of the fiscal year. The second would have blocked the use of statistical sampling during the 2000 census. Republicans gambled that Clinton would not dare to follow through on his veto threat, or that if he did, he would pay a terrible political price for holding up badly needed flood aid for the Midwest. However, that turned out to be a serious miscalculation. Clinton vetoed the bill immediately after he got it on June 9, and the public directed its anger at 
congressional Republicans. Republican congressional leaders finally decided to cut their losses. On June 12, they sent Clinton a second flood aid bill, which he immediately signed into law (HR1871 - PL 105-18).

Meanwhile, Clinton was having troubles of his own as House Democrats refused to support the renewal of his fast-track trade negotiating authority. House Republican leaders began using Clinton's weakness on fast track as leverage to try to seek concessions from him on the four stalled appropriations bills. Gingrich warned Clinton, who had threatened to veto all four spending bills, that conservative Republicans would oppose the fast track authority unless Clinton made concessions on those matters. Compared with the tumultuous House, the Senate was calm, because the Senate was traditionally more favorably disposed to trade initiatives. On Nov. 4 and Nov. 5, senators passed the trade bill by a surprisingly large margin. But the House never acted. Clinton was unable to rally Democrats, and the bill was shelved for the year on Nov. 10.

The final months of the session witnessed rancorous partisan fights over campaign finance reform. The legislative compromise in the beginning of the $105^{\text {th }}$ Congress had not prevented the parties from going into partisan warfare. The session's final days were most painful for Clinton, because he saw three of his major foreign policy initiatives go down in less than a week - the renewal of his fast-track trade negotiating authority, a plan to pay off back debts to the United Nations, and a proposed $\$ 3.5$ billion commitment to help underwrite an International Monetary Fund (IMF) program to deal with global financial crises. Clinton, in response, made the first use of the new line-item veto law, striking individual items in nine appropriations bills and the two reconciliation measures. Although he used the power with relative caution, it provoked an angry 
bipartisan backlash when he struck 38 projects from the military construction spending bill. Congress finally ended the year poised to overrule him.

The 1998 CQ Almanac starts its congressional record of the year by observing, "the House took 547 roll call votes and the Senate took 314 , but history is likely to take note of just two: the House votes Dec. 19 to impeach President Clinton" (1-3). Clinton's affair with former White House intern Monica Lewinsky and his denial under oath of a sexual relationship dominated the political agenda of Washington for the whole year. From the time the curious details of the relationship began to emerge in January, the scandal took center stage for both the administration and Congress. Even when the scandal momentarily took a back seat to other urgent initiatives or crucial decisions, Republicans and Democrats found themselves asked time and again for their opinions on the president's conduct and possible punishments, not about legislative details. Congress created much of the quagmire that ensued, especially when the House voted on Sep. 11 to release the sensational details of Independent Counsel Kenneth W. Starr's report and his conclusion that 11 counts of impeachable offenses could be upheld. That action significantly intensified the partisan wrangling that lasted until the end of the year.

The second session of the $105^{\text {th }}$ Congress was notable for what it did not do. It failed to pass a budget resolution or a major tax cut bill. ${ }^{48}$ Many Republican

\footnotetext{
${ }^{48}$ In the second session of the $105^{\text {th }}$ Congress, the Senate voted 11 times in 29 attempts to invoke cloture. The result was a 38 percent success rate for Majority Leader Trent Lott, R-Miss. In the first session, cloture was invoked seven times in 24 attempts, a 29 percent rate. Technically, invoking cloture allows the leaders to break off filibusters. But true filibusters - in which opponents hold the floor for hours on end to stymie supporters of a bill - have become rare. Now, simply the threat of a filibuster prompts leaders to file a cloture motion to gauge support for a measure. The number of cloture votes also speaks to the continued level of partisanship in the Senate. Democrats spent all year assailing Republicans for minimal accomplishments, and Republicans spent the year declaring that was because the Democrats were thwarting the popular will (1998 CQ Almanac, 1-4).
} 
congressional leaders believed that voters' support for Clinton would eventually decline as it became clear that he had at least misled the public and at worst had lied to a grand jury, and they thought Republicans would reap the benefits at the next election. With these thoughts in mind, they did not push a legislative agenda as strongly as they had in previous years. As a result, for the first time since the modern budget process was established in 1974, Congress did not pass a fiscal budget resolution. In the meantime, Clinton took advantage of the delayed budget negotiations to shift the focus from his own troubles to the Democrats' agenda of 100,000 new teachers and tighter curbs on managed care. Democrats scored some important victories in the budget deal, including a $\$ 1.1$ billion down payment on Clinton's new teacher program. ${ }^{49}$

In 1999, Republican congressional leaders were hard-pressed to lay the groundwork for the 2000 presidential election campaigns. But the first session of the $106^{\text {th }}$ Congress was undermined by the bitter partisanship left over from Clinton's impeachment by the House in December 1998 and his trial and acquittal in the Senate in early 1999. Congress made little legislative progress in $1999 .{ }^{50}$ As the CQ Almanac summed up the situation: "power between the parties is divided, congressional majorities are narrow, civility is on the decline - and a pivotal election is on the horizon" (1999 CQ Almanac, 1-3).

${ }^{49}$ Clinton vetoed five bills in 1998 , bringing the total for the $105^{\text {th }}$ Congress to eight. Lawmakers did not attempt to override any of the 1998 vetoes. However, lawmakers did succeed in overriding one of the three 1997 vetoes, salvaging a bill (HR 2631) that restored \$287 million in military construction spending. An attempt to override a second 1997 veto - of a bill (HR 1122) to ban what sponsors describe as "partial birth" abortions - failed in the Senate Sept. 18 (1998 CQ Almanac, 1-5).

${ }^{50}$ During the first session of the $106^{\text {th }}$ Congress, though lawmakers were busy - they took 985 recorded votes, the third-highest number in the decade - bill signings were far less frequent. The number of bills enacted into law, 170, was the third-lowest in 10 years. The number of bills and resolutions introduced was 6,593 in total; 2,352 in the Senate and 4,231 in the House, the third-highest number in the decade (1999 CQ Almanac, 1-5). 
Clinton had some good news and some bad news in 1999. On the bright side, he was acquitted by the Senate on Feb. 12 of charges that he committed perjury and obstructed justice. The first article was rejected, 45-55; the second article was rejected, 50-50. A two-thirds majority would have been required to convict. It was second impeachment trial of a United States president. According to Ware (2001), “divided government became much more a matter of confrontation between the president and the party leaderships in the Congress... In some respects, therefore, the Clinton impeachment proceedings can be understood as the culmination of a long-term movement towards partisan warfare operating through divided government" (34).

President Clinton continued to suffer from partisan politics in Congress. The Senate's rejection of a treaty to expand restrictions on nuclear testing was one of Clinton's most embarrassing foreign policy setbacks. Votes in the spring on the military deployment in Kosovo were also muddled by partisan sentiment and unwillingness to go too far out on a limb. On a tie vote, the House rejected a symbolic resolution (S Con Res 21) to endorse the air bombing campaign that Clinton had launched five weeks before. A month later, the Senate narrowly blocked an amendment to the annual defense authorization bill (S 1059 - PL 106-65) that would have required Clinton to get express congressional permission before deploying ground troops. In sum, both Republicans and Democrats spent much of the year blaming each other for what was not going to pass and fighting over credit for the rest.

For the second session of the $106^{\text {th }}$ Congress, more turned out to be less. While president Clinton has signed more than 370 laws in 2000, dozens of those measures were to name post offices and public buildings. Neither Republicans nor Democrats made big 
scores in enacting key initiatives. ${ }^{51}$ The presidential election campaign jammed the legislative gears a bit, but there were other factors to blame for the unproductive session. According to Sarah Binder, "institutional dynamics" wreaked as much havoc as political obstacles. For instance, "House and Senate Republicans could not agree how to proceed on politically difficult measures such as broader federal regulation of managed-care plans, which died in a House-Senate conference. While House Republicans pushed legislation they knew could pass with their razor-thin majority, Senate Republicans were less eager to engage in the procedural wrangling necessary to move their priorities. Senate Democrats mastered the art of the filibuster and used it well” (2000 CQ Almanac, 1-3).

The budget debate intensified shortly before the scheduled Oct. 6 adjournment, when Republicans decided to reverse the pattern of earlier years and refused to give in to Clinton's spending demands. As a result, the two sides battled bitterly over the final appropriations measures, passing 22 continuing resolutions while they tried to finish their work. Facing hostile partisanship from the majorities in both the House and the Senate, in the meantime, Clinton continued to use the presidential veto and veto threat to win major concessions from Congress on a range of issues through the end of his term (LeLoup \& Shull, 2003, 3). ${ }^{52}$

In sum, during the period, President Clinton suffered a serious setback in implementing his domestic agenda and his foreign policies as well. His leadership was

\footnotetext{
${ }^{51}$ During the second session of the $106^{\text {th }}$ Congress, a total of 410 public laws were enacted. Bills/Resolutions were introduced 4,247 in total, 1,546 in the Senate, 2,701 in the House. The number of recorded votes was 901 in total, 298 in the Senate, 603 in the House. Clinton vetoed 7 times, and no vetoes were overridden by Congress (2000 CQ Almanac, 1-6).

${ }^{52}$ Clinton vetoed 37 bills during his two terms, including 14 appropriations bills. Congress overrode him only twice, enacting measures to limit shareholder lawsuits (PL 104-67) and to restore military construction spending that Clinton had struck using his short-lived, line-item veto power (PL 105-159) (2000 CQ Almanac, 1-5).
} 
critically weakened and damaged due mainly to partisan opposition from the Republican majority in Congress. This troubled interbranch relationship, along with the intensified partisan politics, significantly influenced his foreign policy choices toward North Korea.

\subsubsection{Presidency vs. Congress: North Korea}

Clinton often found it more difficult to deal with the Republican critics of his Korea policy in Congress than with North Korean counterparts, particularly under divided government. Despite the conclusion of the Agreed Framework in 1994, the Clinton administration was either unable or unwilling to abide fully by its terms due in large part to the resistance of Congress after the Republican victory in 1994. A number of conservative Republican members of Congress attempted to constrain Clinton's flexibility in managing the Agreed Framework and the Korean Energy Development Organization (KEDO) operations.

The Geneva Agreed Framework in 1994 and KEDO Agreement in 1995 both immediately triggered intense partisan wrangling between the President Clinton and the Republican-controlled Congress. The Republicans, with majorities in both chambers of the Congress after the midterm elections in 1994, took advantage of the North Korean nuclear issue to criticize Clinton's foreign policy. They claimed that Clinton had offered too many concessions to Pyongyang in return for its compliance with the IAEA's fullscope safeguards agreement.

The Republican Congress labeled the Agreed Framework a product of Clinton's appeasement policy. In January, 1995, Senator Frank Murkowski (R-AK) criticized the 
agreement in these terms, and Senator John McCain (R-AZ) also declared that the Clinton administration "has extended carrot after carrot, concession after concession, and pursued a policy of appeasement based, in my view, on the ill-found belief that North Koreans really just want to be part of the community of nations and want diplomatic relations" (Mathis, 1994). Steven Mufson, Washington Post columnist, appropriately and concisely summarized the perception and attitude of Republican lawmakers toward the Agreed Framework:

To many Republicans, remedying the flaws in the accord represented more than a matter of bargaining. It became a moral crusade. With reports trickling out about repression and starvation in North Korea... many Republicans decided that the United States should view the Kim Jong Il regime as one of unmitigated evil. Rather than look for a reason to reengage North Korea and renegotiate the Agreed Framework, they wanted to rip it up completely, not only ending the construction of the new, somewhat safer reactors but also cutting off fuel oil shipments to the North. After all, they were only propping up an immoral regime (cited in Carpenter \& Bandow, 2004, 48-49).

Efforts from the Republican Congress to block or modify the agreement followed. In March 1995, the Senate adopted an amendment by Murkowski barring the use of new funds to implement the Agreed Framework. Republicans said the agreement would not succeed in preventing North Korea from developing nuclear weapons. Jesse Helms (RNC) also tried to bar use of any other funds for the agreement without congressional 
approval, but in vain. In June 1995, the House voted on an amendment to the foreign aid authorization bill that would have required that Congress be notified of any reprogramming of funds within accounts that already were authorized and appropriated by Congress for implementing the deal. The Clinton administration objected to the restriction.

In September 1995, the House approved a resolution calling for stricter terms in the deal with Pyongyang, urging that South Korea be declared "the only acceptable source" for the LWRs. Representative Doug Bereuter (R-NB), Chairman of the International Relations Subcommittee on Asia and the Pacific, sponsored the resolution saying, "North Korea remains an outlaw state that will not easily adapt itself to international norms" (as cited in 1995 CQ Almanac, 10-24). But Representative Lee H. Hamilton (D-IN), ranking Democrat on the International Relations Committee, argued that such a resolution "still amounts to a unilateral rewriting of the U.S.-North Korean agreed framework" and "makes the president's job all the more difficult" (as cited in 1995 CQ Almanac, 10-24). In the Senate, Mitch McConnell (R-KY), Chairman of the Appropriations Subcommittee on Foreign Operations, proposed to bar U.S. energy aid to North Korea, unless the North lived up to previous commitments to establish political and economic ties with the South. In a letter to senators, the State Department declared that enactment of his provision would "greatly hinder, if not destroy" efforts by the Clinton administration to implement a nuclear agreement with North Korea (as cited in 1995 CQ Almanac, 11-44).

Congress also made it difficult for Clinton to provide economic aid to North Korea. Representative Sonny Callahan, chairman of the House Appropriations 
Committee, proposed to provide only $\$ 3$ million of the $\$ 22$ million sought by the White House to live up to the agreement. Clinton used the threat of a veto. As a result, Callahan offered an amendment to raise the money to $\$ 13$ million, still far short of the president's proposal. Likewise, the Senate also recommended cutting funding for the KEDO to $\$ 13$ million. Clinton again used the threat of a veto. Finally, the bill was approved to provide \$22 million (Barilleaux \& Kim, 1999).

In 1996, Clinton even had to use an all-purpose presidential waiver, known as 614(a) authority, to secure funds for KEDO. In 1998, when Clinton requested $\$ 35$ million to pay KEDO obligations, the House responded with zero funds. The House bill, furthermore, prevented the president from using the 614(a) waiver to drum up more assistance for KEDO from other sources. The Senate required the president to certify that North Korea was not selling ballistic missiles to other rogue states and terrorist groups before KEDO funds would be released. After Clinton threatened to veto the legislation, a final compromise met the president's request. However, Congress retained a "Special Authorities Amendment" that restricted the executive branch from using the 614(a) waiver to authorize more than the $\$ 35$ million already appropriated by the Congress. Finally, Congress warned Clinton that the 614(a) waiver could be repealed, if abused. Nonetheless, Clinton had to use the waiver again to secure a total of $\$ 65.1$ million for KEDO — \$30.1 million more than Congress had appropriated (Lee \& Miles, 2006, 163).

Thus, presidential budget requests for the delivery of heavy fuel oil to North Korea were often not sufficient to meet the cost of the oil. Even in the years that Congress fully appropriated the request, however, Clinton had to secure money from other sources. By the time the Agreed Framework was nullified in 2002, the Clinton and 
Bush administrations had together spent almost $\$ 90$ million more on KEDO than Congress had earmarked for the program (Lee \& Miles, 2006, 161).

Table 7 shows the executive expenditures on KEDO vs. congressional appropriations from FY1996 to FY2002.

Table 7. Executive Expenditures on KEDO vs. Congressional Appropriations, 1996-2002

\begin{tabular}{|c|c|c|c|}
\hline $\begin{array}{c}\text { Fiscal } \\
\text { Year }\end{array}$ & $\begin{array}{c}\text { Congressional } \\
\text { Appropriations for } \\
\text { KEDO (US\$) }\end{array}$ & $\begin{array}{c}\text { Total U.S. } \\
\text { Expenditures for KEDO } \\
\text { (US\$) }\end{array}$ & $\begin{array}{c}\text { Total Expenditures } \\
\text { above Appropriation } \\
\text { (US\$) }\end{array}$ \\
\hline \hline 1996 & $22,000,000$ & $22,000,000$ & 0 \\
\hline 1997 & $25,000,000$ & $25,000,000$ & 0 \\
\hline 1998 & $40,000,000$ & $50,000,000$ & $10,000,000$ \\
\hline 1999 & $35,000,000$ & $65,100,000$ & $30,100,000$ \\
\hline 2000 & $35,000,000$ & $64,400,000$ & $29,400,000$ \\
\hline 2001 & $55,000,000$ & $75,000,000$ & $20,000,000$ \\
\hline 2002 & $95,000,000$ & $95,000,000$ & 0 \\
\hline $1995-2002$ & $307,000,000$ & $396,500,000$ & $89,500,000$ \\
\hline
\end{tabular}

Note: The Agreed Framework was signed in October 1994, after the appropriations process for the fiscal year 1995 had passed. The Clinton administration informed Congress that approximately $\$ 5.5$ million would be necessary in FY1995 to supply North Korea with the first shipment of heavy oil mandated by the agreement. This payment, along with $\$ 4$ million for administrative expenses, was made by reprogramming FY1995 Department of Defense funds. (The actual payment was made to KEDO in October 1995, the first month of FY1996.)

SOURCE: Adapted from K. Lee \& A. Miles. (2006) "North Korea on Capitol Hill.” In J. Feffer (Ed.), The Future of US-Korean Relations: The Imbalance of Power. New York: Routledge, 162.

Thus, the Republican Congress continued to obstruct the implementation of the Agreed Framework through its purse power. In 1998, Representative Sonny Callahan (RAL) said, "we do not dictate [policy to the administration]. However, I [am] firmly 
convinced that we ought to move beyond the current policy of the Korean Energy Development Corporation" (as cited in Miles, 2005).

In addition, the presidential certification process became more and more complex, narrowing the negotiating space for the executive branch in dealing with Pyongyang, and these complications became increasingly salient during the Bush administration. The House International Relations Committee approved the American Overseas Interests Act (HR 1561 - H Rept. 104-128, Part I) on May 15, 1995, providing authorization for both the State Department and foreign aid accounts. The vote was 23-18 on party lines. The bill proposed to fold the three independent agencies-U.S. Agency for International Development, U.S. Arms Control and Disarmament Agency, and the United States Information Agency — into an expanded State Department, mandated deep cuts in aid for poor countries, and included provisions to require changes in North Korea policy. The bill required that even small amounts of aid for North Korea, provided as part of the 1994 Geneva Agreement, must go through congressional reprogramming procedures, making it easier for Republican members of Congress to block the assistance (1995 CQ Almanac, 10-4).

The normalization of political and economic relations with North Korea also encountered opposition from the Republican Congress. The Clinton administration could not proceed rapidly to lift sanctions against North Korea because of the opposition. Robert Gallucci, the chief negotiator of the 1994 Agreement, complained that "congressional and press skeptics and critics did lead us to take the minimum interpretation of sanctions lifting" (as cited in Carpenter \& Bandow, 2004, 50). In 1999, Representative Benjamin Gilman (R-NY), chairman of the House Committee on 
International Relations, introduced an amendment to the 1995 American Overseas Interests Act in order to require that Clinton take further steps toward upgrading diplomatic relations with North Korea only if and when North Korea entered into a dialogue with South Korea on several issues. ${ }^{53}$ The House approved the amendment, 305120. The amendment would prevent any U.S.-North Korea agreement on nuclear issues from taking effect unless Congress enacted a joint resolution saying that North Korea had complied with international non-proliferation agreements. In particular, Gilman's amendment would require Pyongyang to implement the 1994 Geneva Agreement to freeze its nuclear weapons program and allow international inspections before receiving international aid.

Other critics also argued that LWRs were not necessarily "proliferation-resistant." James A. Baker III, former secretary of state under President George H. W. Bush complained that "our policy of carrots and sticks gave way overnight to one of carrots only-fuel oil to help run North Korea's beleaguered economy, two new nuclear reactors, and diplomatic ties" (as cited in Lee, 2006, 181-82).

A leading Republican candidate for president, Robert Dole (R-KS), declared that "a bad deal is often much more worse than no deal at all" and asserted that "the greatest immediate security threat in Asia is the Stalinist regime in North Korea, armed to the teeth, determined to develop weapons of mass destruction and the means to deliver them.... President Clinton failed to hold North Korea to its 1991 commitments to resume bilateral North-South talks and to work with South Korea for a nuclear-free Peninsula.

\footnotetext{
${ }^{53}$ Representative Edward J. Markey of Massachusetts also sponsored this amendment with Gilman (1999 CQ Almanac, 14-10).
} 
His accommodation of North Korea, and his neglect of our ally's well-founded concerns, set a pattern that has continued to this day: appeasing the North, slighting the South, and ignoring the strategic consequences" (as cited in Lee, 2006, 185). He also criticized the Agreed Framework as a giveway to one of the world's last hard-line communist outposts (1996 CQ Almanac, 10-52).

Therefore, President Clinton faced a difficult challenge to make the Agreed Framework and KEDO work efficiently and effectively. He did not want his North Korea policy to become a potentially explosive campaign issue readily exploitable by the Republicans. However, heavily constrained by fiscal and legal limits from the Republican-controlled Congress, Clinton could not play a decisive leadership role in improving U.S.-North Korea relations, especially through KEDO. Because of the lack of financial and legal support from Congress, Clinton had to calibrate his North Korea policy carefully and often heavily rely on South Korea and Japan for assisting with the delivery of heavy oils to North Korea.

In the meantime, when the Republican Party became a majority in both chambers of Congress as a result of the midterm elections in September 1994, the new Republican majority requested that the Clinton administration appoint a North Korea Policy Coordinator. This was another way for the Congress to criticize Clinton's North Korea policy and was one of the most successful efforts by congressional Republicans to constrain Clinton's leadership and initiative as well. A new provision in the "Omnibus Consolidated and Emergency Supplemental Act (PL 105-277)" in October 1998 mandated that "not later than January 1, 1999, the President shall name a North Korea Policy Coordinator, who shall conduct a full and complete interagency review of United 
States policy toward North Korea, shall provide policy direction for negotiations with North Korea related to nuclear weapons, ballistic missiles, and other security related issues, and shall also provide leadership for United States participation in KEDO." This bill imposed several stringent conditions on the use of a fund of \$35 million available for KEDO, and it required the president to certify that "the United States is fully engaged efforts to impede North Korea's development and export of ballistic missiles" (as cited in Lee, 2006, 195-96).

Clinton appointed former Secretary of Defense William J. Perry as the North Korea policy coordinator in late 1998. Perry immediately found himself caught between the wishes of the president and the interests of the Congress. The views of the Republican Party were so sharply divergent from the Clinton administration's North Korea policy that mutual consensus on a new policy was highly unlikely. For example, Representative Gilman (R-NY) criticized the Agreed Framework as a "deeply flawed accord that has failed to change North Korea's behavior as it was predicted it would" (as cited in Lee, 2006, 196). He believed that "North Korea has used the Agreed Framework as a cover for their real goal: the ability to deliver nuclear weapons against the United States by the end of the century" (as cited in Lee, 2006, 196). He also denounced the four-party talks as "so ineffective and so meaningless to North Korea that there has been great difficulty in even arranging a date for the next meeting" (as cited in Lee, 2006, 196).

Representative Dana Rohrabacher (R-CA) also labeled Clinton's North Korea policy "the most nonsensical program he had ever heard of" (as cited in Lee, 2006, 196). Furthermore, he declared that "when it comes to North Korea, our goal should not be the status quo, it should not be stability; our goal should be the overthrow of that government 
and the replacement of that government with something that is more consistent with the democratic values our country is supposed to represent" (as cited in Lee, 2006, 196).

Criticism of Clinton's North Korea policy was not limited to Republicans. A group of policy analysts headed by Richard L. Armitage, former Assistant Secretary of Defense for International Security Affairs, issued a report on "A Comprehensive Approach to North Korea” in March 1999. The report characterized Clinton's policy as "fragmented," "reactive," and "politically unsustainable." The report also recommended that if diplomacy failed, the United States should take a more ready and robust posture, including a willingness to interdict North Korean missile exports on the high seas. This approach was realized as the "Proliferation Security Initiative (PSI)" during the next Bush administration, and Armitage further recommended that the United States consider the option of preemption, based on "precise knowledge of North Korean facilities, assessments of probable success, and clear understanding with our allies of the risks" (as cited in Lee, 2006, 196). This approach came to be called "the Bush Doctrine" and was declared part of the 2002 National Security Strategy of the United States of America during the next Bush administration.

Perry paid a visit to Pyongyang from May 25 through 28, 1999. On the trip, he carried a letter from Clinton addressed to Kim Jong Il. He wanted to see Kim Jong Il, but was unsuccessful. In early September 1999, Perry submitted his report to President Clinton and the Congress. The Perry Report was based on a "two-path" strategy. If the North accepted the path of cooperation, the report recommended that the United States should normalize relations with North Korea, relax economic sanctions, and take other "positive steps." If Pyongyang chose the path of confrontation, however, the report 
recommended that Washington take measures to contain North Korea. The report negatively "characterized North Korea as isolated, reprehensible, enigmatic, suspicious, and vulnerable and referred to its longstanding record of blackmail, threats, and provocations" (Lee, 2006, 198).

The Perry Report, however, did not mollify the deeply entrenched Republican critics of Clinton's North Korea policy. In November 1999, just a few weeks after the release of the Perry Report, the North Korea Advisory Group in the House of Representatives consisting of nine leading Republican House members chaired by Benjamin Gilman (R-NY) submitted the Gilman Report to Speaker J. Dennis Hastert (RIL). The Gilman report criticized Clinton for his soft approach to North Korea, which allowed it to be a direct threat to the United States, and concluded that Clinton's North Korea policy did not address this military threat, that food aid was poorly monitored, and that the US government did not address other critical issues such as drug trafficking, terrorism, counterfeiting, and human rights (North Korea Advisory Group [NKAG], 1999).

The food aid issue was a "red flag" for the North Korea Advisory Group, which continuously used the issue of monitoring to focus their attack. They NKAG argued that if monitoring remained unsatisfactory, the Secretary of State should consider changes in U.S. policy on food aid to North Korea. Democrats criticized the report. Representative Tony Hall (D-OH), for example, complained that the report had a "negative bias" without offering proof. Evoking former Republican president Ronald Reagan, he said, "if we refuse to help people who live under brutal regimes, even when we can hide behind the excuse that we can't absolutely guarantee they are getting food, we are betraying 
President Reagan's policy that a hungry child knows no politics" (as cited in Lee \& Miles, 2006, 164). The issue of food aid monitoring, however, did not gain sufficient traction during the Clinton administration.

Since the Republicans just wanted to "highlight what they considered deficiencies in the Clinton's administration's approach" (Hathaway \& Tama, 2004, 714), the North Korea Advisory Group "did not articulate a coherent alternative to administration policy or make a concerted effort to overturn it" (Hathaway \& Tama, 2004, 732). But it still had a destructive impact on Clinton's North Korea policy, making him unable for supporting the 1994 Geneva agreement, and reluctant to improve diplomatic relations between Washington and Pyongyang.

The Gilman Report clearly contrasted with the Perry Report. The former concluded that North Korea's comprehensive threat to the United States had increased since the Agreed Framework was signed. It also claimed that the Perry Report did not adequately address other North Korean issues such as human rights, political and economic liberalization, terrorism, drug trafficking, political prisoners, and counterfeiting. It claimed that U.S. economic assistance had been delivered to help sustain a dictatorial regime in North Korea. The result, the Gilman Report declared, was that "North Korea can now strike the United States with a missile that could deliver high explosive, chemical, biological, or possibly nuclear weapons" (as cited in Lee, 2006, 199). Thus, the Perry process was expected to face continuing obstacles and difficulties from the Republican Congress.

The Clinton administration, however, continued to adhere to the Geneva Agreed Framework and the KEDO agreement, but its annual delivery of heavy fuel oil to North 
Korea encountered continuous restrictions and delays because the Republican Congress was increasingly skeptical and critical of Clinton's North Korea foreign and nuclear policy. This partisan acrimony intensified when Kumchang-ri in North Korea began to emerge as a new suspected nuclear site. It would be a serious violation and breach of the Geneva Agreed Framework. Suspicions about Kumchang-ri also arose just when partisanship in U.S. politics was culminating in the partisan impeachment of President Clinton by the Republican legislators in late 1998. Another crisis also broke out in 1998, caused by Pyongyang's sudden launching of a Taepodong missile, a multi-stage rocket that flew over Japan into the Pacific, in apparent response to U.S. accusations regarding the suspected nuclear site at Kumchang-ri.

Not surprisingly, the Republicans immediately capitalized on the missile launch as another opportunity to criticize Clinton's North Korea policy, presenting it as hard evidence of the policy's failure. Representative Robert Livingston (R-LA), chairman of the House Appropriations Committee, said, “I just don't see any reason to proceed with this failed policy" (as cited in Carpenter \& Bandow, 2004, 51). He further argued that funding for the Agreed Framework "should be discontinued" and that the Clinton administration "ought to stop talking to them, stop appeasing them," because it is "a pretty good excuse just to get out of this agreement" (as cited in Carpenter \& Bandow, 2004, 51). Republican Senator Frank Murkowski criticized the 1994 agreement as "folly" and added, "our carrot-and-stick approach is all carrots and no stick... We were too quick to provide North Korea with the goodies before we knew the truth" (as cited in Carpenter \& Bandow, 2004, 53). 
In the House, even Benjamin Gilman (R-NY), Republican moderate, took a hard line, arguing that the 1994 agreement was "fatally flawed," while Representative Christopher Cox (R-CA) said, "U.S. policy is conducting a one-sided love affair with the regime in North Korea" (as cited in Carpenter \& Bandow, 2004, 55). Representative Sonny Callahan (R-AL) also proclaimed, "I have said from the beginning that KEDO is an irresponsible policy that we never should have entered into in the first place. But the administration chose to do it, an we have funded it for the last 4 or 5 years, but it is time to take a serious look at KEDO, especially in light of the fact they are now shooting missiles over Japan and indications are that they have missiles that very possibly could reach Alaska" (as cited in Lee \& Miles, 2006, 163).

Convinced that the Kumchang-ri facility housed a covert nuclear weapons program, the Republican Senators also "reacted sharply to these actions and added two provisions to the fiscal year 1999 foreign aid bill that had the effect of killing Clinton's nonproliferation policy. One amendment, proposed by John McCain, conditioned aid to KEDO on a presidential certification that North Korea had halted its nuclear program (or on a waiver on national security grounds). The other amendment, proposed by Senator Dan Coats (R-Ind.), required that the administration share intelligence data on North Korea's nuclear program with congressional committees. Congressional Quarterly described these two votes as "the end of administration plans"” (Barilleaux \& Kim, 1999).

The crisis, however, was finally defused in March 1999, after North Korea allowed the U.S. officials to inspect alleged nuclear site at Kumchang-ri, and the U.S. inspection team had found no evidence of a clandestine nuclear program there. On March 6, 1999, the United States and North Korea released a joint statement in which North 
Korea agreed to allow the U.S. delegations to access and inspect the site at Kumchang-ri. After the visits and the inspection, the group of fourteen American technical experts concluded that the site did not violate the Geneva Agreed Framework. In order to reward Pyongyang for its cooperation with Washington over the Kumchang-ri site and its moratorium on long-range missile tests and to support and implement the Perry process, the Clinton administration decided on September 17, 1999, to relax the economic sanctions against North Korea administered under the Trading with the Enemy Act, the Defense Protection Act, and the Export Administration Regulations. However, the rapid pace of U.S.-North Korean rapprochement provoked the Republicans to launch another partisan attack against Clinton's North Korea policy, which they took to be an "appeasement policy." This attack clearly and evidently had partisan overtones in the context of the presidential contest between Al Gore and George W. Bush.

Republican congressional leaders continuously maneuvered to increase restrictions on the U.S. delivery of heavy fuel oil to North Korea and on the U.S. transfer of nuclear facilities and materials necessary for the LWR project in North Korea. On July 19, 2000, they attempted to pass the "North Korea Nonproliferation Act of 2000" (H.R. 4860), which was intended to require a mandatory re-imposition of economic sanctions against North Korea if Pyongyang launched a long-range missile again or transferred missiles or missile technology to any country included on the U.S. list of state sponsors of terrorism. A report prepared by the 39-member House Policy Committee chaired by Christopher Cox (R-CA) also stated that "North Korea is not merely a dictatorship: it is a uniquely monstrous tyranny that has tormented the Korean people for half a century, creating the most completely totalitarian and militarized state in human history. Today, 
even while North Korea is faltering on the edge of economic collapse, it poses one of the greatest threats to American and allied interests anywhere around the globe" (Cox, 2000, Web).

The report argued that "enhancements to North Korea's threatening military capabilities, centered on the development of nuclear weapons and long-range delivery systems.... are subsidized with U.S. taxpayer funds provided by the Clinton-Gore administration" (Cox, 2000, Web). Under the Clinton administration, according to the report, "North Korea has become the largest recipient of U.S. foreign aid in the AsiaPacific region" (Cox, 2000, Web). It also notes, "along with Clinton-Gore foreign aid, North Korea's long-range missile development continues to this day" (Cox, 2000, Web). Like the Gilman Report, this report also criticized the Perry Report as an extension of appeasement policy and denounced the Clinton administration's naivete in using U.S. taxpayers' money to meet the demand of "this despicable Stalinist regime"” (Cox, 2000). The House adopted an amendment by Representative Doug Bereuter (R-NB) that would "bar the federal government from indemnifying U.S. companies that supplied parts for nuclear power plants built in North Korea" (2000 CQ Almanac, 2-77). The same provision has been included in the fiscal 2001 defense authorization bill (HR4205).

In sum, during the period of divided government, both chambers of Congress with the Republican majorities challenged, obstructed, and paralyzed Clinton's North Korea policy. In so doing, the Republicans took advantage of all the political weapons given to them by the Constitution. Sometimes, they even succeed in effectively reversing U.S. policy toward North Korea as stipulated in the agreements already signed by the two countries. As a result, President Clinton could not live up to the 1994 Geneva Agreement, 
and had to give up his travel to Pyongyang for a deal on North Korea's nuclear and missile issue. ${ }^{54}$ The result was a pronounced shift away from a conciliatory policy and toward a status quo policy on North Korea.

\subsection{Conclusion}

In 1993-4, President Clinton adopted a more conciliatory policy toward North Korea under a unified government, which led to the 1994 Geneva Agreement. Clinton was able to do so, because he could expand the win-set with strong support from Congress. In 1995-2000, however, divided government and partisan politics heavily constrained President Clinton in his dealings with North Korea.

During the period, Congress wielded considerable power to limit Clinton's ability to negotiate with North Korea, to support the 1994 agreement, and to establish a new relationship with North Korea. Congress exercised its appropriations power by cutting the funding for the construction of the two light-water reactors in North Korea and by delaying deliveries of the fuel oil to North Korea on time. Although Congress did not always succeed in obstructing Clinton's leadership on the North Korean issue, "it did manage to erect substantial roadblocks. By routinely hammering the administration, Congress successfully prevented full implementation of the Agreed Framework. The

\footnotetext{
${ }^{54}$ Washington and Pyongyang almost reached a conclusion to end the deal on North Korea's nuclear and missile issue. North Korea wanted President Clinton to come to Pyongyang, but U.S. officials felt it was too risky for Clinton to visit Pyongyang without a firm and verifiable agreement on missile issues in advance, and were reluctant to send the President without finishing the missile deal before the visit. Clinton decided not to go partly because he should have to be prepared in the States for a possible constitutional crisis resulted from the prolonged electoral controversies in Florida over the presidential election between $\mathrm{Al}$ Gore and George W. Bush, and partly because he thought that there was not enough time to finish the missile deal with North Korea (Lee, 2006, 206-07).
} 
resulting delays and hesitations helped to reinforce a lack of trust between the United States and North Korea (Lee \& Miles 2006: 160).”

All of these political challenges made it very difficult for Clinton to live up to the agreement, and therefore Clinton was either unable or unwilling to implement other parts of the agreement. In other words, the extensive and continuous attacks from the Congress mainly deprived the Clinton administration of the opportunity and confidence to take bold steps for the diplomatic improvement between the United States and North Korea. They largely eliminated the win-set in domestic politics that had existed in the first part of his administration. Thus, the shift toward divided government with intensified partisanship also led inevitably to a shift in policy toward North Korea-from a more conciliatory policy in 1993-1994 to a status quo policy in 1995-2000. 


\section{THE PRESIDENCY, THE CONGRESS, AND U.S. POLICY TOWARD NORTH KOREA DURING THE BUSH ADMINISTRATION}

President George W. Bush held office from 2001through 2008. ${ }^{55}$ In 2001-2006, he adopted a more aggressive policy toward North Korea under a unified government and took a tougher stance on the North Korea nuclear issue. In 2007-2008, however, President Bush accepted a more conciliatory policy toward North Korea under a divided government, adopting measures from the Six-Party Talks such as "the Initial Actions for the Implementation" and "the Second-Phase Actions for the Implementation," and removing North Korea from the list of state sponsors of terrorism. This chapter seeks to explain why President Bush, like his predecessor, took two different policy approaches toward North Korea during his term of office.

5.1. The Bush Administration under unified government (2001-2006)

In 2001-6, President Bush moved to adopt a far more aggressive policy toward North Korea than his predecessor. He chose not to negotiate with Pyongyang on the nuclear issue, and he received strong support from Congress in this stance. The result, however, was Pyongyang's first nuclear test in 2006. Then, in Bush's second term, the U.S. gradually adopted a more conciliatory approach. It is impossible to understand this pattern without attention to domestic politics within the United States.

\footnotetext{
${ }^{55}$ For a comprehensive discussion of the Bush presidency, see Rozell \& Whitney, 2009; Schier, 2009. And for a discussion on President Bush's national security strategy, see Leffler \& Legro, 2008.
} 
5.1.1. U.S. Policy toward North Korea during the Bush Administration (2001-2006)

Giving a very good grade to Clinton's foreign policy record, Stephen M. Walt (2000) predicted that no matter who won the 2000 presidential election, his successor would follow much the same course. On policy toward North Korea, at least, this prediction turned out to be wrong. The Bush foreign policy team criticized the 1994 Agreed Framework as "a reward for bad behavior," and characterized Clinton's policy toward North Korea as an appeasement policy and a submission to extortion, even during the 2000 presidential election campaign. Such a hard-line position suggested that the incoming Bush administration would reverse Clinton's policy of constructive engagement toward North Korea. In fact, the foreign policy of the Bush administration in its initial term, particularly toward North Korea, could be described as "ABC""Anything But Clinton." 56

The changes in the United States' North Korea policy resulted, in part, in from President Bush's perceptions on Pyongyang that were quite different from the ones of those of his predecessor. After the inauguration, President Bush ordered a complete policy review. The new administration's perceptions of North Korea were revealed in the terminology they employed: "a failed stated," "a rogue state," "an axis of evil," and "an outpost of tyranny." When Representative John F. Tierney (D-MA), for example, criticized the Bush administration for rushing work on missile defense silos, the

\footnotetext{
${ }^{56}$ Even after the inauguration of the president Bush, the Bush foreign policy team continuously criticized Clinton's North Korea policy as "deeply, profoundly misguided and wrong" (as cited in Martin, 2007, 85).
} 
administration replied that the test interceptors in the five Fort Greely silos could provide a rudimentary defense against a missile fired from North Korea (CQ Almanac 2002, 211). Since its inception, the policy of the Bush administration toward North Korea was grounded in a preference for "asphyxiation" rather than "oxygen," for diplomatic pressure and economic isolation rather than for rewards for cooperation (Martin, 2007, $65)$.

Bush himself bluntly stated that he was skeptical about the North Korean leader and that any negotiation with North Korea would require complete verification of a potential agreement (Lee, 2006, 211). In the 2002 National Security Strategy of the United States of America, North Korea was placed among the rogue states with ballistic missiles and weapons of mass destruction. Although the "rogue state" was one of the new threat images of the United States after the Cold War, rogue states were particularly demonized after the September 11 terrorist attacks. Such Manichaean phraseology, which dominated foreign policy during the Cold War, was given renewed prominence by President Bush's (The White House, 2001; Bush, 2001) declaration, "you are either with us or against us." This logic makes rogue states incomprehensible and irrational, which inhibits negotiations and compromise (Litwak, 2000).

This dualism is also reflected in phrases such as "axis of evil" and "outposts of tyranny." The phrase "axis of evil" was first introduced in the President's state of the Union address in January 29, 2002. In the address, President Bush (The White House, 2002b) lumped together North Korea, Iran, and Iraq, and declared that the United States will never stop fighting against such regimes. The "axis of evil" reference conjured up popular memories of the "Axis Powers" during World War II and Ronald Reagan's 
condemnation of the Soviet Union as the "Evil Empire" during the Cold War (Lee, 2006, 219). In her opening statement before the Senate Foreign Relations Committee,

Condoleezza Rice also designated North Korea as one of the "outposts of tyranny," along with Cuba, Burma, Iran, Belarus, and Zimbabwe. She continued to say that the United States would not stop until “every person living in a 'fear society' has finally won their [sic] freedom" (Rice, 2005, Web).

President Bush also frequently spoke about the North Korean leader in harsh terms. From the beginning of his Presidency, Bush condemned Kim Jong Il as an untrustworthy madman, a pygmy, and an evildoer (Cumings, Abrahamian, \& Ma'oz, 2004, 72). In a discussion with Bob Woodward, he said, "I loathe Kim Jong Il! I've got a visceral reaction to this guy, because he is starving his people" (as cited in Woodward, 2002, 340). Former Defense Secretary William Perry said, "I think he [Bush] has come to the conclusion that Kim Jong Il is evil and loathsome and it is immoral to negotiate with him" (as cited in Cumings, Abrahmian, and Ma'oz, 2004: 73). In one press conference, President Bush (The White House, 2005) referred to Kim Jong Il as a dangerous person and tyrant. In response, North Korea labeled Bush "a half-baked man in terms of morality and a philistine" and "world's dictator" (Kessler, 2005).

Based on these perceptions of North Korea and its leadership, President Bush introduced new issues to his agenda for a comprehensive approach to North Korea. The Bush administration called on Pyongyang to stop selling missiles to countries such as Iraq and Iran, even though such exports did not violate any international agreements. While Clinton centered on stopping North Korea's nuclear program and its missile program, Bush widened the focus to include all weapons of mass destruction, troop 
concentrations, and even internal policy changes (Feffer, 2003, 105). In this way, he actually raised the bar much higher than before and clearly showed his mistrust of North Korea's conventional military behavior as well.

In contrast with the Republican hardliners in Congress, however, Bush did not repudiate the Geneva Agreed Framework altogether. Rather, he clarified that he would not offer material incentives to Pyongyang prior to seeing tangible evidence of its affirmative response and appropriate action. Bush was to rely heavily on sticks in a new North Korea policy that would go by different names such as "hawk engagement" and “tailored containment” (Feffer, 2003, 105). Bush's simplistic, moralistic, Manichaean approach means that any compromise between good and evil was inconceivable and repugnant (Lee, 2006, 219-20).

The terrorist attacks on September the $11^{\text {th }}$ intensified these already uncompromising tendencies. ${ }^{57}$ The 2001 Nuclear Posture Review identified North Korea as a state that might be attacked by U.S. nuclear weapons in the near term. According to the Nuclear Posture Review, "North Korea, Iraq, Iran, Syria, and Libya are among the countries that could be involved in immediate, potential, or unexpected contingencies. All have longstanding hostility toward the United States and its security partners; North Korea and Iraq in particular have been chronic military concerns. All sponsor or harbor

\footnotetext{
${ }^{57}$ The September $11^{\text {th }}$ terrorist attacks definitely had a real effect on President Bush and his foreign policies (Barilleaux \& Zellers, 2009). Some even argue that they radically changed the Bush administration's North Korea policy as well (Hwang, 2004). As this section shows, however, the September 11 rather intensified its previous uncompromising tendencies toward Pyongyang.
} 
terrorists, and all have active WMD and missile programs" (Department of Defense, 2001, 16). ${ }^{58}$ Furthermore, the 2002 National Security Strategy of the United States stated that:

The United States has long maintained the option of preemptive actions to counter a sufficient threat to our national security. The greater the threat, the greater is the risk of inaction — and the more compelling the case for taking anticipatory action to defend ourselves, even if uncertainty remains as to the time and place of the enemy's attack. To forestall or prevent such hostile acts by our adversaries, the United States will, if necessary, act preemptively (The White House, 2002a, 15).

The September $11^{\text {th }}$ terrorist attacks might have sparked a rapprochement between the United States and North Korea. Immediately after the attacks, North Korea expressed its condolences to the victims, announced its intention to cooperate with the United States to counter global terrorism, and "was clearly trying to distance itself from any association with terror tactics, and the idea that it was connected to Islamist terrorist networks, or participated in anything like an 'Axis' with Iraq and Iran” (Armstrong, 2006, 17). It was hard, however, for the Bush administration to imagine North Korea as an ally in the "war on terror." By associating North Korea with global terrorism, instead, the Bush administration invited a hostile response from Pyongyang, aggravated the U.S.-North Korean conflict, and wiped out what remained of progress in relations with North Korea (Feffer, 2003, 106).

\footnotetext{
${ }^{58}$ In a UN conference on nuclear nonproliferation in May 2005, the Bush administration rejected the proposal that called for nuclear states to make a legally binding pledge not to attack countries that do not possess nuclear weapons (Stockman, 2005).
} 
The second nuclear crisis on the Korean peninsula nonetheless came as a shock when North Korea admitted its covert highly-enriched uranium (HEU) program in October, 2002. After visiting Pyongyang from October 3 to 5, 2002, Assistant Secretary of State for Asia and the Pacific James Kelly announced that North Korea had not only admitted the existence of a secret nuclear program, but it justified the program as a response to hostile Bush Administration policies. According to Kelly, when he presented intelligence reports on North Korea's secret program to enrich uranium for nuclear weapons on October 3, Kim Gye Gwan, vice minister of foreign affairs of North Korea, had completely denied the accusation. But, on the following day, Kang Sok Ju, first vice minister of foreign affairs of North Korea, has apparently admitted that North Korea possessed not only the highly enriched uranium (HEU) program but more powerful things as well, and he blamed the hostile U.S. policy for North Korea's self-defense measures. He reportedly added that the Geneva Agreed Framework had been nullified. ${ }^{59}$ The Bush administration then asserted that North Korea had violated the 1994 Agreed Framework, the NPT, the safeguards agreement with the IAEA, and the NorthSouth Joint Declaration on the Denuclearization of the Korean Peninsula. President Bush called on North Korea to dismantle its HEU program immediately. Events began spiraling downward immediately. The following month, the United States, Japan, and South Korea decided to suspend further oil shipments to North Korea, and to reassess a program for constructing two LWRs at Kumho. Bush's unprecedented victories in the midterm congressional elections in November also strengthened his political position in

\footnotetext{
${ }^{59}$ Jeong Se Hyun, South Korean Minister of Unification, reportedly suggested that Kelly had misunderstood Kang Sok Ju's remarks and Kang had not actually admitted the existence of an HEU program in North Korea (Lee, 2006, 223).
} 
dealing with North Korea while weakening the Democratic Party's opposition to his North Korea policy in Congress.

In response, Pyongyang declared the Agreed Framework dead. On 10 January 2003, furthermore, it announced its withdrawal from the NPT and stated that it was no longer bound by its IAEA safeguards agreement. The first round of the Six-Party Talks including North Korea, South Korea, China, Japan, Russia, and the United States, began in August 2003 to resolve the North Koran nuclear weapons issue. The meeting adjourned earlier than expected, however, without bearing any fruit. Although a second round of the Six-Party Talks was held in February 2004, the talks once again failed to achieve even a joint press release. President Bush demanded the "complete, irreversible and verifiable" dismantlement of the North's nuclear weapons program (the CIVD policy). In 2003, in order to support Bush's CIVD policy and "dismantle first" policy, the House proposed the Missile Threat Reduction Act that suggested sanctions on North Korea and any state buying ballistic missiles or related technology from Pyongyang. The House also proposed prohibiting the transfer of nuclear technology to North Korea in an effort to halt the light-water reactor program that had been a part of the Agreed Framework. $^{60}$

\footnotetext{
${ }^{60}$ The light-water reactor program is crucial both for the denuclearization of North Korea and for the improved relationship between Washington and Pyongyang. North Korea has long insisted on energy assistance in the form of light-water moderated reactors in exchange for giving up the graphite-moderated reactors in Yongbyon. The day after the 2005 September Joint Statement was issued, the North Korean Ministry of Foreign Affairs issued a statement of its own: "A physical groundwork for building bilateral confidence is none other than the U.S. provision of light water reactors to North Korea. We strongly demand that the United States remove the very cause that compelled North Korea to withdraw from the Nuclear Non-Proliferation Treaty by providing light water reactors to it" (as cited in Goldstein, 2009). While, the Clinton administration decided to provide North Korea with two light-water reactors in exchange for the freezing of North Korea nuclear program, the Bush administration insisted the complete shutdown of the LWR project. For a recent discussion on the LWR issue, see Goldstein, 2009.
} 
Beginning with the third round of the Six-Party Talks held in Beijing in June 2004, however, the Bush administration started to adopt a more flexible policy than in the earlier rounds. Due mainly to the changed U.S. stance, the fourth round of the Six-Party Talks was finally able to issue the Beijing Joint Statement on September 19, 2005. Shortly after the Joint Statement, however, the Bush administration accused North Korea of counterfeiting of U.S. dollars and money laundering, and froze North Korean bank accounts at Banco Delta Asia. Arguing that the financial sanctions on the bank in Macao showed the reluctance of the United States to change its hostile policy toward North Korea, Pyongyang continued to demand that Washington unfreeze the bank accounts in Macao. Washington's refusal to do so scuttled the Six-Party Talks and finally led to missile launches in July 2006 and a nuclear test in October $2006 .{ }^{61}$ In sum, as seen in the passing and signing of the North Korean Human Rights Act in 2004, the united government under Republican leadership substantially aggravated U.S.-North Korean relations and finally led to a North Korea armed with nuclear weapons.

Based on its new foreign policy principles after the terrorist attacks on September $11^{\text {th }}$, the Bush administration narrowed its policy toward North Korea down to three options: military action with a preemptive strike (the most aggressive option), containment with malign neglect (the status quo option), and engagement with diplomatic negotiations (the most conciliatory option). Some neoconservatives clearly preferred a preemptive strike. They opposed any political and economic incentives that would help to sustain North Korean regime. Following Jeane Kirkpatrick's views on totalitarian

${ }^{61}$ For more detailed discussions on the missile launches in 2006, see Cotton, 2006; Koh, 2006; T. Kim, 2006; Sigal, 2006; Hayes, 2006a; Hayes, 2006b; Lim, 2006; Feffer, 2006; Cheong, 2006; Pinkston, 2006. And for more detailed discussions on the Banco Delta Asia issue, see Hauben, 2007; K. Kim, 2007; T. Kim, 2007; Cowie, 2006. 
regimes, neoconservatives believed that the North Korean system could not be reformed from within. They were ready and willing to risk a major military conflict with North Korea, if it was necessary to stop the spread of WMDs and to change the totalitarian regime in Pyongyang. Richard Perle said that "the United States would have to consider a surgical air strike to eliminate the nuclear plant at Yongbyon, which he said was a relatively easy target" (Schifferes, 2003). When John R. Bolton, former U.S. Ambassador to the United Nations, was asked what the Bush policy was toward the North, he reportedly answered by pointing at a book entitled The End of North Korea (Cumings, Abrahamian, \& Ma'oz, 2004, 71-2). In June, 2003, Bolton declared that the United States would use all means necessary to eliminate weapons of mass destruction in all rogue states (emphasis added, Feffer, 2003, 112).

Although not all neoconservatives preferred the military option, all of them evidently opposed to the engagement policy toward North Korea. Later, Bolton called the 2007 Initial Actions for the Implementation of the Joint Statement "a bad deal" that violated principles that were strongly held in the beginning of the Bush administration (Kessler, 2007). Dan Blumenthal and Aaron Friedberg, furthermore, argued that the SixParty Talks were "a step in the wrong direction," rewarding "the world's worst regime" for its bad behavior, and Nicholas Eberstadt expressed his discontent with the deal, complaining that "the Bush administration's North Korean climb-down has been almost dizzying to watch... it was proffering a zero-penalty return to the previous nuclear deals Pyongyang had flagrantly broken - but with additional new goodies, and a provisional free pass for any nukes produced since 2002, as sweeteners" (as cited in McCormack, 2007, 9). All of them were worried that if it were not stopped any time soon, North Korea 
would be able to produce about sixty nuclear devices annually and could then easily sell them to other rogue states and the international terrorist organizations. They thus argued that, if necessary in the face of an imminent threat, the United States should launch a unilateral, surgical strike against North Korea nuclear facilities, even without South Korean consent.

There were three main reasons, however, why Washington could not choose this military option. First, the United States did not know how many nuclear weapons North Korea had already produced and where any North Korean nuclear weapons might be located. Second, the surgical strike by Washington might have caused a full-scale military conflict on the Korean Peninsula that the United States could not afford, because a large portion of the United States military capabilities were already committed to Afghanistan and Iraq. Finally, most neighboring countries including South Korea, Russia, and China, strongly opposed the military option.

The administration's second option was the containment policy of "malign neglect," which was chosen by President Bush for most his term. Many neoconservatives preferred this policy. Georgy Bulychev (2007) has noted that the idea of "the neoconservatives in 2002-2006 was that regime change was the solution to the WMD threat, and that no concessions were to be made to the North Korean regime, which was about to collapse anyway and should be assisted by in that by sanctions, isolation and subversive activities. Such an approach also fitted nicely with US geopolitical aims containing China (and Russia) and strengthening its alliance with Japan” (Web).

In pursuit of these goals, the Bush administration refused to negotiate with North Korea, declaring that it would "talk" but not "negotiate" until the $4^{\text {th }}$ Six-Party Talks held 
in Beijing, China, in July 2005. U.S. officials said that such "talks" would in no way constitute "negotiations" (Carpenter \& Bandow, 2002, 81). Bush simply demanded that North Korea follow the CVID principle. During the Beijing Six-Party Talks in 2003, James Kelly was "forbidden from making any offers or suggesting even the possibility of direct negotiations" (Kaplan, 2004, 41). President Bush “let Kelly talk, but didn’t let him say anything meaningful; he went to the table but put nothing on it" (Kaplan, 2004, 41). In protest, Charles Pritchard resigned from the Bush administration, saying that "my position was the State Department's envoy for North Korean negotiations, yet we were prohibited from having negotiations" (Kaplan, 2004, 42). His retirement indicated that the hard-liners were firmly in control of the administration's North Korea policy (Carpenter \& Bandow, 2004, 85). ${ }^{62}$

Graham Allison (2007) has summarized several key elements of the Bush administration. First, it demanded CVID as a precondition for anything else. Second, it did not want to provide any reward for bad behavior. Third, it refused any bilateral negotiations. The Bush administration chose this approach for the following four reasons. First, it did not want to be distracted from the war in Iraq by North Korea. Second, some neoconservatives in the Bush administration preferred this approach in the hope that North Korea would collapse quickly due to its political and economic failures. They thought that the time was not on North Korea's side. Third, the Bush administration wanted to give the impression to the rest of the world that it did not reward bad behavior. Finally, the administration believed that giving in to blackmail would lead only to more

\footnotetext{
${ }^{62}$ See Pritchard (2007) for his "personal, first-hand account of the development and implementation of U.S. policy toward North Korea during the first term of President George W. Bush" (ix).
} 
blackmail. The Bush approach did not work, however, because Pyongyang ignored Washington's behavior and perceptions. North Korea likes to act rather than to react, a preference that may have resulted from the North Korean Juche ideology of self reliance (Park, 2002, 148). The North Korean nuclear test epitomizes this self reliance.

Lastly, there was the option of engagement through diplomatic dialogue and negotiations for the Bush administration, which Clinton chose in his presidency in the 1990s. As seen above, until the $4^{\text {th }}$ Six-Party Talks in 2005, the Bush administration was not willing to negotiate with North Korea in earnest. The Bush administration demonstrated its changed attitude in the $4^{\text {th }}$ Six-Party Talks, however, which resulted in an agreement with a joint statement in September 2005. This attitude change resulted from the combined political pressures from inside such as the decline of presidential job approval ratings and a power shift from hawks to moderates in the second Bush administration, and from outside, such as the worsening situation in Iraq and pressures for sincere negotiation from China and South Korea.

Immediately after the Beijing Joint Statement, however, the Bush administration accused North Korea of counterfeiting of U.S. dollars and money laundering and froze North Korean bank accounts at Banco Delta Asia in order to make the agreement invalid. These accusations "added another layer of complications that detracted from progress in the Six-Party Talks tasked with engaging North Korea in a productive dialogue" (Olsen, $2007,48)$. North Korea responded to the accusations by withdrawing from the Six-Party Talks, by launching missiles on the fourth of July 2006, and by finally conducting a nuclear test in October 2006. 
In sum, U.S. policy toward North Korea changed, during the first six years of the Bush Presidency, from the status quo policy that characterized the last Clinton years to a policy of outright hostility. Bush backed away from all negotiations and issued a series of strong threats. In response, North Korea implemented more hostile actions of its own. By 2006, relations between the U.S. and North Korea were at one of the lowest points since the conclusion of the Geneva Agreement in 1994.

\subsubsection{Presidency vs. Congress: Overview}

The $107^{\text {th }}$ Congress opened with an evenly divided Senate, a House that Republicans controlled by just six votes, and a president put in office by the Supreme Court after an election that was too close to call $1{ }^{63}$ The session began with Republicans in control of both White House and Congress for the first time since president Dwight D. Eisenhower. Though their majority was slim, they managed to push through a massive tax cut (PL 107-16), Bush's first top priority, and take significant steps on a rewrite of the 1965 Elementary and Secondary Education Act, Bush's second top priority. By the time the session ended, however, the Senate had shifted to a Democratic majority, and Congress' agenda had been turned upside down by the Sept. 11 terrorist attacks. ${ }^{64}$

\footnotetext{
${ }^{63}$ In the Senate, the even split of 50 Republicans and 50 Democrats left the tie-breaking vote of Vice President Dick Cheney as the GOP's only edge.

${ }^{64}$ During the first session of the $107^{\text {th }}$ Congress in 2001, a total of 136 public laws were enacted. A total of 6,521 bills/resolutions were introduced (2,203 in the Senate and 4,318 in the House). The number of recorded votes was 892 ( 380 in the Senate and 512 in the House). There were no vetoes by President Bush (2001 CQ Almanac, 1-7).
} 
The year can be divided into three phases. The first phase was a period of oneparty government, with Republicans narrowly controlling Congress and President Bush making the most of his tentative mandate in the early months of his presidency. During the period, it was conventional wisdom that, given his narrow electoral victory, Bush lacked a mandate for sweeping changes and would have to limit his agenda to proposals that had bipartisan support. From the start, however, Bush made it clear he would ask as much from Congress as he would if he had won a landslide victory. In June, the defection of moderate Republican James M. Jeffords of Vermont abruptly turned the Senate over to the Democrats, ending the short-lived period of Republican control of Congress and the White House. ${ }^{65}$ The switch allowed Senate Democrats to challenge the GOP agenda and press forward on some of their own issues. ${ }^{66}$

The final phase began on Sept. $11 .{ }^{67}$ After a period of uncertainty and paralysis, members of Congress regrouped to rewrite their agenda and search for ways to retain their party identities while rallying around the flag. Foreign and defense policy came to the fore again for the first time since the end of the Cold War. Senators Tom Daschle (DSD) and Trent Lott (R-MS) delivered a bipartisan joint response. "We want President Bush to know, we want the world to know, that he can depend on us," Daschle said. "We will take up the president's initiatives with speed. We may encounter differences of

\footnotetext{
${ }^{65}$ Jeffords left the Republican Party saying that he foresaw many disagreements with Bush over issues such as tax and spending decisions, the direction of the judiciary, abortion, missile defense, energy and the environment. But the biggest, he said, was education - mainly because Bush was not willing to put more funding behind the education overhaul, particularly special education (2001 CQ Almanac, 1-6).

${ }^{66}$ It took the Senate until the end of June to adopt a new organizing resolution to replace the power-sharing agreement Trent Lott and Tom Daschle had worked out for the 50-50 Senate (2001 CQ Almanac, 1-6).

${ }^{67}$ For a short chronology of the September $11^{\text {th }}$ terrorist attacks, see the 2001 CQ Almanac, 1-10. For a long version, see The New York Times, The 9/11 Report (2004, New York: St. Martin's Press).
} 
opinion along the way, but there is no difference in our aim. We are resolved to work together" (as cited in 2001 CQ Almanac, 1-9).

Gradually, however, the bipartisan stance all congressional leaders adopted after the September $11^{\text {th }}$ attacks began to break down. With an election that could determine the control of both chambers less than a year away, both parties looked for ways to win the approaching midterm elections. Daschle started using a two-track strategy for his party: supporting Bush on the war on terrorism on one hand, while challenging Republicans on domestic issues on the other hand. "I agree with what the president is doing right now on the international front. I strongly disagree with him on many of the economic questions," he said on Dec. 6 (as cited in 2001 CQ Almanac, 1-11). In response, Republicans started calling Daschle an "obstructionist" who was blocking Bush's agenda and could not get anything done.

Despite the midyear change in the Senate, Bush was able to shape much of what Congress accomplished in 2001. However, the most precious lesson from the first session of the $107^{\text {th }}$ Congress was that a narrowly divided Congress did not necessarily guarantee the bipartisan cooperation that the American public wanted from the Congress. After the near tie in the 2000 elections, congressional leaders from both parties said the results represented a mandate for cooperation. But the result was just the opposite. With control of the House and Senate within reach for either side in 2002, the parties spent most of their energy trying to satisfy their political bases and strengthen their congressional position.

In 2002, the second session of the $107^{\text {th }}$ Congress approved the biggest reorganization of government since World War II, and it opened the door to a 
fundamental shift in U.S. foreign policy by authorizing President Bush to launch preemptive strikes to overthrow Saddam Hussein and disarm Iraq. ${ }^{68}$ Most of the year was shaped by the ongoing impact of the terrorist attacks of Sept. 11, 2001, which continued to redraw the political landscape at home and abroad. In an effort to help the government do a better job of preventing future attacks, Congress voted to pass legislation creating the Cabinet-level Department of Homeland Security. And to eliminate the possibility that Iraq could launch attacks against the United States or its neighbors with weapons of mass destruction, or give such weapons to terrorist organizations such as al Qaeda, Congress also authorized Bush to take military action against Iraq. The resolution encouraged Bush to seek the support of the United Nations first, but it authorized the United States to go to war with or without U.N. approval as well.

In the Senate, the session was dominated by the political struggle, because the change of just one seat in the November midterm elections would be sufficient to shift the majority from the Democrats to the Republicans. With 50 Democrats, 49 Republicans and one independent, the margin of control was so close that the neither party could avoid fighting over it. The power struggle exposed the dual political reality of the second session of the $107^{\text {th }}$ Congress: lawmakers generally were unified on the war against terrorism, but divided on domestic issues. Moreover, the fight for control of the Senate guaranteed gridlock on almost all legislation that was not urgent.

From the moment Bush delivered his first official State of the Union address on Jan. 29, it was evident that foreign affairs issues would take a top priority. Bush spent the

\footnotetext{
${ }^{68}$ During the second session of the $107^{\text {th }}$ Congress in 2002, a total of 241 public laws were enacted. The number of bills/resolutions introduced was 4,274 in total, 1,563 in the Senate, and 2,711 in the House. The number of recorded votes was 739 in total, 253 in the Senate, and 484 in the House. No vetoes were used by the president Bush (2002 CQ Almanac, 1-6).
} 
first half of his speech on the fight against al Qaeda and other terrorist groups to make Americans more secure at home. Bush specifically singled out Iraq, Iran, and North Korea as an "axis of evil" that was arming to threaten the security of the United States and world peace, more generally. It was no wonder, therefore, that protecting the homeland was the underlying theme of the second session of the $107^{\text {th }}$ Congress. In addition to passing the homeland security bill and authorizing the U.S. war in Iraq, Congress created an independent commission to investigate the Sept. 11 attacks.

On another front, lawmakers sought to address the issue of corporate scandals such as those surrounding Enron Corp. and WorldCom Inc. ${ }^{69}$ In order to prevent the same problems from happening again, Congress voted to pass a bill overhauling the nation's campaign finance laws on the theory that lax oversight was connected to cozy patronage relationships. Congress also granted fast-track trade negotiating authority to Bush, passed a six-year farm bill that reversed a 1996 policy of limiting federal price supports, and responded to the turmoil of the 2000 presidential election by creating new standards for federal elections and authorizing $\$ 3.9$ billion in grants to the states over three years to meet them. But the second session of the $107^{\text {th }}$ Congress also left a long list of unfinished business. For example, Congress failed to produce a budget resolution. Efforts to pass a stimulus bill to address the nation's economic slump bogged down in deep partisan and ideological divisions.

The Iraq issue played a pivotal role in the November midterm elections. The debate was a boost to Republicans, while it proved damaging to Democrats. Not only did

\footnotetext{
${ }^{69}$ Both were fueled by accounting fraud that forced massive layoffs, devastated workers' retirement savings, and added to the stock market turmoil that played havoc with the finances of millions of Americans (2002 CQ Almanac, 1-3-4).
} 
foreign policy issues tend to favor the Republicans, but they also directed attention away from Democratic efforts to talk about the economy and domestic issues. After the election, Republicans held the House, and with a net shift of two seats, they recaptured the Senate.

In 2003, the opening session of the $108^{\text {th }}$ Congress marked the first time in 50 years that Republicans had clear control of both chambers and the White House. They used the opportunity to implement Bush's top legislative agendas. ${ }^{70}$ All of this came against the backdrop of the war in Iraq, the fall of Saddam Hussein's government, and the triumphant capture of Saddam Hussein by year's end. Having authorized the president to launch the war in 2002, Congress was reduced to the role of bystander when the fighting broke out, with little authority to do anything but pay the bills. ${ }^{71}$

Yet congressional Republicans did not always succeed with their agendas. Six of Bush's judicial nominations were held up by filibusters in the Senate. Against Democrats' charges that that Bush was nominating conservative extremists, Republicans were unable to round up the votes to break the deadlock. Some of Bush's second-tier priorities - such as limiting medical malpractice awards, redesigning Head Start, and rewriting clean air standards - were also sidetracked or left to an uncertain fate in the second session of the $108^{\text {th }}$ Congress. However, Republicans were convinced that they were building a solid

\footnotetext{
${ }^{70}$ During the first session of the $108^{\text {th }}$ Congress in 2003, a total of 198 public laws were enacted. The number of bills/resolutions introduced was 7,014 in total, 2,398 in the Senate, and 4,616 in the House. The number of recorded votes was 1,136 in total, 459 in the Senate, and 677 in the House. President Bush issued no vetoes (2003 CQ Almanac, 1-6).

${ }^{71}$ For criticisms of congressional inactivity during the war in Iraq, see Ohaegbulam, 2007; Hansen \& Friedman, 2009.
} 
record of accomplishments for the presidential election of the following year on the biggest issues such as the war on terrorism, the economy, and health care.

This year also was one of increasingly bitter partisanship even by the standards of the previous several years. When Senate Democrats blocked six of Bush's judicial nominations, Senate Republicans responded by shutting all Democrats out of the HouseSenate conference committee that wrote the energy bill, and excluded all but two centrist Democrats from the conference committee that wrote the final Medicare bill. In retaliation, Senate Democrats blocked attempts to begin conference negotiations on two other bills. The signs of such partisanship were not only anecdotal. Congressional Quarterly's analysis of "party unity" votes in 2003 clearly showed that "Congress was more polarized than it had been in the five decades that CQ had analyzed the annual voting patterns on Capitol Hill” (2003 CQ Almanac, 1-4). According to the CQ analysis:

Democrats and Republicans in both chambers stuck together tightly. The average House Republican voted with his party on 91 percent of the party unity votes, while the average Senate Republican did so 94 percent of the time - the highest unity score ever for Senate Republicans. Senate Democrats, meanwhile, stuck together 85 percent of the time, while House Democrats did so 87 percent of the time, their highest unity score since 1960 (2003 CQ Almanac, 1-4).

Meanwhile, Bush enjoyed almost complete control of the Congress. He won the second major tax cut of his presidency and a Medicare overhaul. He got every penny he requested for the war in Iraq. While Congress staged some resistance to Bush's second- 
tier policies, the president was usually able to get Congress to back down with few concessions. "There were drawbacks, but the president certainly got what he wanted," said George C. Edwards III, political scientist at Texas A\&M University (as cited in 2003 CQ Almanac, 1-4).

In 2004, election-year politics and relentless partisan wrangling dominated the second session of the $108^{\text {th }}$ Congress. With the exception of a groundbreaking overhaul of the intelligence community, no major legislative themes dominated Congress. ${ }^{73}$ Instead, the year was mostly about positioning for the November presidential elections. Hanging over the entire session was President Bush's campaign for re-election and Massachusetts Democratic Sen. John Kerry's attempt to unseat him. The race was so tight for so much of the year that lawmakers from both parties became active participants. The partisan wrangling that characterized the year certainly reflected the heated presidential campaign, but it also reflected the increasing tendency for members of Congress to play to their core constituencies. Congressional Quarterly's annual study of party-unity votes showed that 2004 was the second-most partisan year in the five decades the voting studies had been done, surpassed only by 2003 (2004 CQ Almanac, B-8).

The impact of the election went beyond campaigning. Members of Congress from both parties used the machinery of Congress and their votes to improve their images with voters. Party leaders also worked hard to sharpen distinctions between the parties and to

\footnotetext{
${ }^{72}$ The partisan unity also explains why the Bush administration received such a favorable hearing on its Iraq policy in Congress from 2001-2006 (Howell \& Pevehouse, 2007).

${ }^{73}$ During the second session of the $108^{\text {th }}$ Congress in 2004, a total of 300 public laws were enacted. The number of bills/resolutions introduced was 3,655 in total, 1,317 in the Senate, and 2,338 in the House. The number of recorded votes was 760 in total, 216 in the Senate, and 544 in the House. President Bush issued no vetoes (2004 CQ Almanac, 1-6).
} 
rally their troops to vote in ways that highlighted those distinctions. They also sought votes that they believed would put their opponents in a bad light. The November presidential election returned Bush to the White House with 51 percent of the popular vote and increased Republican control of both chambers of Congress. Senate Republicans picked up four seats, expanding their majority for the next Congress to 55. House Republicans ended up 232 seats - a net gain of three, their largest elected majority since 1995.

In 2005, when the first session of the $109^{\text {th }}$ Congress opened, Representative David Dreier (R-CA), Chairman of the House Rules Committee, said, "We begin the new Congress with a sense of purpose and optimism. It's been a long time since Republicans have had this much power in Washington" (as cited in 2005 CQ Almanac, 1). Emboldened by the party's increased control in the Senate, Majority Leader Bill Frist (RTN) used his opening speech on Jan. 4 to warn Democrats: "exercise self-restraint and do not filibuster judicial nominees" (as cited in 2005 CQ Almanac, 1). Furthermore, Republican House leaders made it clear they would punish party members who were not sufficiently loyal. ${ }^{74}$ Republicans had competently maintained party unity in the control of Congress. In the House, their party loyalty increased a bit over 2004, though not quite matching the record high in 1995. But in the Senate, the level of party unity and cohesion

\footnotetext{
${ }^{74}$ Representative Christopher H. Smith (R-NJ) was removed as chairman of the Veterans' Affairs Committee on the first day of the session. The position was to be replaced by Representative Steve Buyer (R-IN). Smith had frequently clashed with Republican congressional leaders in his bid to increase funding levels for veterans' programs. It was the first time since Republicans took power a decade before that they deposed a sitting chairman (2005 CQ Almanac, 1-4).
} 
of the Republicans dropped well below the level they had reached in the highly partisan 2003 session. $^{75}$

In the meantime, Democrats were demanding strict adherence to party discipline. As a result, House Democrats were more unified in 2005 than at any time in the previous half-century. In a similar vein, Senate Democrats were almost as united as they had been at their high point in 1989. Overall, congressional Republicans maintained a 90 percent unity rate on party unity votes, while Democrats were close behind at 88 percent (2005 CQ Almanac, B-8). As a result, Republicans could not automatically translate their larger majority into victory, particularly in the Senate. With Democrats united in opposition, Republican congressional leaders had to keep their caucus in tight lockstep to maintain cohesive party unity. They could not always accomplish this level of party loyalty, however, especially when the Republican caucus was badly fragmented toward the end of the year.

In 2006, with the November midterm elections approaching, the second session of the $109^{\text {th }}$ Congress was a time of partisan standoff and limited accomplishments. ${ }^{76}$

President Bush used his first veto in July when the Senate cleared a bill (HR810) that would have lifted restrictions on federal funding for embryonic stem cell research. The House had passed the measure in 2005. Bush had strongly warned that he would veto the embryonic stem cell bill, which was anathema to social conservatives who equated the

\footnotetext{
${ }^{75}$ During the first session of the $109^{\text {th }}$ Congress in 2005 , a total of 147 public laws were enacted. The number of bills and resolutions introduced was 8,319 in total, 2,616 in the Senate, and 5,703 in the House. The number of recorded votes was 1,037 in total, 366 in the Senate, and 671 in the House. No presidential vetoes were issued (2005 CQ Almanac, 1-8).

${ }^{76}$ During the second session of the $109^{\text {th }}$ Congress, a total of 313 public laws were enacted. The number of bills and resolutions introduced was 4,753 in total, 2,302 in the Senate, and 2,451 in the House, The number of recorded votes was 822 in total, 279 in the Senate, and 543 in the House. President Bush used his veto power once (2006 CQ Almanac, 1-8).
} 
destruction of embryos with abortion. It was also clear that neither chamber had the votes to override his veto. In a carefully planned series of events, therefore, Bush vetoed the bill on July 19. The embryonic stem cell bill died that day, because it fell 51 votes short of the two-thirds majority needed to override the president.

As the year went on, Republican congressional leaders increasingly suffered because of the unpopularity of the president, the deepening public dismay over the Iraq War, and sometimes their own missteps. As a result, Republican members of Congress became more independent and divided as they looked to their own needs in advance of the election. Democrats, on the other hand, were united. That was particularly noticeable in the House. Although Republicans still prevailed most of the time in party unity votes, Democrats in both chambers voted as a unanimous bloc more often than did Republicans. It was the first time that had happened in the House since 1986.

The Republican electoral defeat in November 2006 finally ended an era of Republican control of the Capitol - one that had lasted a dozen years, except for 18 months in 2001 and 2002 when the Democrats held the narrow edge in the Senate. It also ended the Speakership of J. Dennis Hastert of Illinois, who held the job longer than any House Republican in history. The verdict in the midterm elections on Nov. 7 was worse for the Republicans than most of them had feared, and far better for the Democrats than most of them had hoped. Democrats claimed outright control of Congress for the first time since 1994. They picked up 30 seats to take back the House after a dozen years in the minority and gained six seats to win back control of the Senate, which Republicans had held since the 2002 midterm elections. Democrats also won 20 of the year's 36 gubernatorial contests. 
The dismay and anger of voters over the war in Iraq, Bush's unpopularity, the scandals and the shortage of congressional accomplishments all contributed to the Republican's crushing defeat. The decision of Democrats to accuse Republicans of creating a "culture of corruption" in Washington proved timely. In addition, although Democrats lacked consensus on how to end the Iraq War, they presented a mainly united and vocal front in criticizing Bush's handling of the war. They also successfully recruited some centrist Democrats who were able to win in mildly GOP-leaning districts or states. Two-thirds of the seats gained by the Democrats in both chambers in this election were in districts or states that jut two years earlier had favored Bush for president over Kerry.

In sum, however, President Bush enjoyed strong support from Congress during his first six years in office. After the terrorist attacks on September $11^{\text {th }}$, in particular, both chambers of Congress lent unprecedented bipartisan support to President Bush in the name of national security. Although partisanship and partisan politics gradually intensified as the September 11 terrorist attacks receded into the past, challenges from Democratic legislators were never substantial or far-reaching during these days. Under unified government from 2001 through 2006, President Bush was able to enjoy a quasiimperial presidency (Schlesinger, 1973).

\subsubsection{Presidency vs. Congress: North Korea}

During Bush's first six years under unified government with Republican majority in Congress, Republicans had shifted away from resisting the full implementation of the Agreed Framework and the KEDO agreements toward a more aggressive stance on issues 
such as North Korea's role in international terrorism, drug trafficking, and counterfeiting, as well as humanitarian concerns such as food aid, human rights, and refugees. During the period, Congress created obstacles to U.S. aid to North Korea, not only because of the North Korean nuclear proliferation issue, but also because of Pyongyang's record on human rights and refugees. ${ }^{77}$

In Bush's first six years, the administration's North Korea policy showed a strong resemblance to the arguments and strategies initiated and developed by Republican members of Congress during the Clinton administration. After conducting a guerrilla war in 1994 against the Agreed Framework, which it regarded as "deeply flawed" and a case of "appeasement and bribery" (Martin 2007, 87), the Republican Congress continued to shape and constrain any efforts to cooperate with North Korea. Furthermore, encouraged by the Bush administration to widen its focus beyond the nuclear issue, Congress used hearings, resolutions, and legislation to play a critical role in determining how the United States would resolve both the nuclear issue and its human rights issues during the first six years of the Bush presidency (Lee \& Miles, 2006, 160-61).

Senator Jesse Helms (chairman, Senate Committee on Foreign Relations), Representative Henry Hyde (chairman, House Committee on International Relations), Representative Christopher Cox (chairman, Republican Policy Committee), and other participants in the Gilman Report in 1999 exerted enormous influence over President Bush. President Bush could not ignore their policy recommendations, partly because he was not experienced in the foreign policy area, and partly because he needed their help

\footnotetext{
${ }^{77}$ Early in the Bush presidency, it was assumed among conservatives that North Korea could be collapsed by a mass exodus of refugees. For more details, see Lee \& Miles, 2006, 165.
} 
and support to pass his legislative agenda in Congress. On the eve of the summit meeting between Bush and South Korean President Kim Dae Jung in 2001, Representative Hyde, Cox, and Edward J. Markey even signed a joint letter to the president in which they pointed out the deficiencies of the Geneva Agreed Framework. In the letter, they urged the president "to avoid making any commitments to foreign governments that would prejudice your ability to refine U.S. policy toward North Korea" (as cited in Lee, 2006, 214). The Bush administration could not disregard such strong anti-North Korean sentiments in the Congress.

Just as Republicans during the Clinton administration attempted to take advantage of every major turn of events on North Korea, Democrats during the Bush administration were not reluctant to make use of the opportunities that came their way. In Spring 2003, the Democrats criticized the contradiction in Bush's policies toward Iraq and North Korea, accusing Bush of being obsessed with the removal of Saddam Hussein while disregarding the North Korean nuclear issue. They warned that North Korea posed a more direct and imminent threat to the interests of the United States and its allies and the sustainment of the nuclear nonproliferation regime than Iraq did. They urged Bush to play an active role in addressing the threat from Pyongyang. Senate Minority Leader Tom Daschle (D-SD) complained, "We have repeatedly urged the administration to get off the sidelines and face up to the developing crisis. The White House continues to sit back and watch, playing down the threat, and apparently playing for time. But time is not on our side" (as cited in Lee, 2006, 230). Senator Robert C. Byrd (D-WV) also pointed out that the North "presents a far more imminent threat than Iraq to the security of the United 
States" (as cited in Lee, 2006, 230). And Senator Biden complained that Bush's policy toward North Korea was paralyzed by interbureaucratic infighting.

Meanwhile, Republicans "maneuvered to block U.S. assistance for the KEDO operations and LWR projects in Kumho, to condemn the violations of human rights in North Korea, to admit North Korean refugees to the United States, to seek the return of the Pueblo, and to increase Radio Free Asia's broadcasting with respect to North Korea to twenty-four hours a day" (Lee, 2006, 230) ${ }^{78}$ In particular, the North Korea Democracy Act of 2003 (S. 145) cosponsored by Senators Jon Kyl (R-AZ) and John McCain (R-AZ), Elizabeth H. Dole (R-NC), and five other Republican colleagues prescribed a wide range of restrictions, requirements, and sanctions in U.S. relations with North Korea. It stipulated, "It is the sense of Congress that the United States, in conjunction with the Republic of Korea and other allies in the Pacific region, should take measures, including military reinforcements, enhanced defense exercises and other steps as appropriate, to ensure-(1) the highest possible level of deterrence against the multiple threats North Korea poses; and (2) the highest level of readiness of the United States and allied forces should military action become necessary (quoted in Lee 2006: 230-1)." Furthermore, Senator Jon Kyl (R-AZ) introduced a measure requiring an annual report from the president describing North Korea's role in international drug trafficking, which was not enacted (Lee \& Miles, 2006, 170). Representative Porter Goss (R-FL) even recommended using undercover agents to penetrate North Korean government (Martin,

\footnotetext{
${ }^{78}$ In 1968, North Korea seized the Pueblo, a U.S. Navy intelligence ship monitoring Soviet traffic. North Korea has not returned the ship ever since.
} 
2007, 88). These proposed acts clearly reflected the prevailing views of Republican members of Congress.

On October 18, 2004, President Bush finally signed the North Korean Human Rights Act (PL 108-333) sponsored by Representative James Leach (R-IA), Chairman of the House International Relations Subcommittee on Asia and the Pacific. This law was a revised version of 2003 North Korea Democracy Act. The law contained a long list of human rights abuses perpetrated by the North Korean government and a variety of recommendations to support human rights and democracy in North Korea. The law also called for the appointment of a Special Envoy for Human Rights in North Korea within the State Department. The Special Envoy was expected to provide an annual report on the activities of the office and was given a budget of $\$ 24$ million for four years to support to the programs for human rights and democracy in North Korea. In August 2005, President Bush appointed Jay Lefkowitz as Special Envoy for Human Rights in North Korea.

The law appeared to be a punitive measure. It also sent a mixed message to North Korea. At the time the act was passed, the Six-Party Talks has been suspended for several months with little hope of breaking the deadlock soon. South Korea, in particular, expressed strong reservations about the law. Chung Dong-young, South Korean Unification Minister, argued that the law would ruin South Korea's "quiet diplomacy" approach. As he put it, "human rights problems in communist countries have never been solved by way of applying pressure" (as cited in Lee \& Miles, 2006, 167). Lee Booyoung, Chairman of the governing Uri Party, also expressed his concern about the law, saying it would have a negative impact on Pyongyang's foreign policy making. 
Despite recommendations that the North Korean human rights issue be separated from the nuclear weapons issue, the law linked them together and thereby caused further deterioration of the U.S.-North Korean relationship. Representative James Leach (R-IA) stated that "the NKHRA is motivated by a genuine desire for improvements in human rights, refugee protection, and humanitarian transparency. It is not a pretext for a hidden strategy to provoke regime collapse or to seek collateral advantage in ongoing strategic negotiations" (as cited in Lee \& Miles, 2006, 167). Nevertheless, Pyongyang immediately used the Human Rights Act as evidence of hostile U.S. intent toward North Korea, making the law a pretext for its boycott of the Six-Party Talks. In this way, the passage of the North Korean Human Rights Act compounded the difficulty of dealing with the North Korean nuclear issue (Olsen, 2007, 48).

After the passage of the North Korean Human Rights Act, Congress continued to exert strong influence on the Bush Administration's North Korea policy. The May 2005 remarks of Representative James Leach (R-IA), at a speech at the Conference on "Prospects for U.S. Policy toward the Korean Peninsula in the Second Bush Administration," clearly sum up the common Republican perceptions of North Korea. Leach declared, "With each passing month, North Korea increases its nuclear weapons capabilities. As a consequence, the odds may have increased that Pyongyang could export nuclear weapons or fissile material to foreign governments, shadowy middlemen, or even terrorists... [T]he party that threatens stability in Northeast Asia is North Korea" (Leach, 2005). The End Dictatorship, Assist Democracy Act of 2005, furthermore, set a goal of transforming the North Korean government, along with 44 other dictatorial governments, through nonmilitary means. Congress also condemned the September 2005 Joint 
Statement. Finally, in October 2006, the North Korea Non-Proliferation Act urged "all governments to comply with the United States Security Council Resolution 1695.” However, the stunning Democratic victory in the 2006 midterm elections dramatically weakened Republican congressional control over North Korea policy, and compelled the Bush administration to take a more conciliatory approach (Martin, 2007, 88).

In sum, during the period from 2001 through 2006, the Republican majority in Congress wielded every possible institutional weapon to change Clinton's North Korea policy by resisting the implementation of the Agreed Framework and the KEDO agreements. Despite persistent opposition from Democratic legislators, the Bush administration successfully changed the U.S. policy toward North Korea from conciliation to confrontation. The consequences of this transformation are described in the next section.

5.2. The Bush Administration under Divided Government (2007-2008)

Beginning in 2007, President Bush retreated toward a status quo policy on North Korea, primarily because he could not gain enough support from the Democratic majority in Congress to continue his preferred, more aggressive North Korea policy. In all but name, Bush began to do what he had vowed not to do: to negotiate with Pyongyang. In response, relations between the two countries slowly began to retreat from the brink. 
5.2.1. U.S. Policy toward North Korea during the Bush Administration (2007-2008)

On February 13, 2007, by agreeing on the Initial Actions for the Implementation of the 2005 Joint Statement in the third session of the fifth round of Six-Party Talks, the Bush administration finally decided to negotiate with North Korea ${ }^{79}$ Several changes in the international environment compelled President Bush to choose the engagement policy toward North Korea. First, it was difficult, if not impossible, to use the military option since North Korea already had become a nuclear power, and considerable U.S. military capabilities were already committed in Iraq and Afghanistan. Second, Iran's increasingly confrontational policy toward the United States forced the Bush administration to think that Mahmoud Ahmadinejad had become more dangerous than Kim Jong Il, that Iran had become the greater threat than North Korea, and that dealing with Tehran on its nuclear issue had become more urgent than dealing with North Korea. The Bush administration wanted to resolve the North Korean issue through diplomacy in order either to put pressure on Iran to negotiate away its nuclear program, or to prepare for the possible expansion of the battlefield in the Middle East to Iran by neutralizing North Korea, in case the negotiation with Tehran were to fail.

In addition, several changes in domestic politics also required the Bush administration to adopt a more conciliatory policy toward North Korea. First, since the Bush administration had diplomatically failed in Iraq and Afghanistan, it needed to find major foreign policy achievement somewhere else for the purposes of the 2008

\footnotetext{
${ }^{79}$ Many North Korea experts have indeed argued that this option is the only way to achieve a peaceful diplomatic solution to the North Korean nuclear issue. For example, see Quinones, $2007 \mathrm{~b}$.
} 
presidential election campaign. North Korea was a good target because the North Korean problem, for all its complexity, was nevertheless easier than the Middle East issue. Above all, however, after the loss of majorities in both chambers of the U.S. Congress in the 2006 midterm elections, President Bush could not ignore the demand both by moderate Republicans and by most Democrats to negotiate with Pyongyang in earnest for the denuclearization of North Korea. Historically, presidents after midterm election defeats have been less likely to respond to foreign policy issues aggressively (Howell \& Pevehouse, 2007). In short, President Bush had no choice but to change and adjust his North Korea policy. Under the circumstances, the Bush administration "took an abrupt about-face in North Korean policy... when the Neocons lost influence in Washington as a result of Congressional power shift from Republicans to Democrats. Since then the Bush administration has engaged North Korea intensely to resolve the nuclear issue" (Kim, 2008, Web).

Since North Korea conducted its nuclear test on October 9, 2006, the relationship between Washington and Pyongyang had experienced a swift change. In the midst of efforts by the international community to seek specific measures to meet the United Nations Security Council Resolution 1718 condemning Pyongyang's nuclear test, North Korea returned to the Six-Party Talks. On February 13, 2007, unexpectedly, in the third session of the fifth round of the Six-Party Talks, all agreed on the Initial Actions for the Implementation of the 2005 Joint Statement, which was regarded as the first concrete step for the denuclearization of the Korean peninsula. This agreement was possible because President Bush had sent Assistant Secretary of State Christopher Hill to Beijing and Berlin to have bilateral talks with his North Korean counterpart Kim Kye Gwan to 
discuss the return of North Korea to the Six-Party Talks and the conclusion of the Initial Actions Joint Statement. ${ }^{80}$

On October 3, 2007, "the Second-Phase Actions for the Implementation of the September 2005 Joint Statement" was announced at the end of the second session of the six round of the Six-Party Talks. The Second-Phase Actions Joint Statement was the result of the meetings on September 1-2, 2007. Despite the suspected Syria-North Korea nuclear link, Bush once again authorized Assistant Secretary of State Christopher Hill to meet his North Korean counterpart Kim Gye Gwan for a series of bilateral talks. In the "Second-Phase Actions" Joint Statement, Pyongyang agreed to disable the reactor, reprocessing facilities, and fuel fabrication plant at Yongbyon and list the nuclear material and equipment. It also undertook not to transfer nuclear materials, technology, or know-how to third parties. Washington, in return, would fulfill its commitment to terminate the Trading with the Enemy Act and remove North Korea from the list of statesponsor terrorism.

On June 26, 2008, by reporting its nuclear programs to participants in the SixParty Talks, and by destroying the cooling tower at its nuclear site with financial help from Washington, Pyongyang dramatically showed the world its determination to dismantle its nuclear weapons program. In return, the White House removed North Korea from the list of state sponsors of terrorism and lifted some economic sanctions imposed under the Trading with the Enemy Act (Department of State, 2008).

\footnotetext{
${ }^{80}$ The critics of the agreement denounced it as simply "the revival of the logic and scope of the old Agreed Framework" in 1994 (Hayes, 2007).
} 
In sum, during the final two years of the Bush Presidency, the divided U.S. government produced more status quo policies toward North Korea than a unified U.S. government had in 2001-6. Because President Bush could no longer receive strong support from Congress, he had to change his policy toward North Korea from aggression to conciliation. Although this represented an important change in U.S. policy toward North Korea, the result was essentially status quo. Not only was the Bush administration in a lame duck situation after the 2006 mid-term elections, but it no longer had the time to conclude a deal with Pyongyang.

\subsubsection{Presidency vs. Congress: Overview}

In 2007, the first session of the $110^{\text {th }}$ Congress opened with Democrats in control of both chambers for the first time in 12 years. Invigorated by their victory in the 2006 midterm elections, the Democrats immediately laid out an ambitious agenda that included setting a time-table for ending the war in Iraq, revving up spending on domestic programs such as education and health care, and cleaning up what they had characterized during the campaign as a "culture of corruption" on Capitol Hill under the Republicans. While Democratic Representatives passed a resolution condemning a proposed "surge" of U.S. troops in Iraq, Democrats Senators debated a series of resolutions against the war in Iraq. The spring 2007 supplemental appropriations debate resulted in a House bill calling for a phased withdrawal from Iraq. Democratic leaders in both chambers of Congress launched hearings and investigations into a variety of foreign policy issues (Howell \& Pevehouse, 2007). As a result of the Democratic Party's slim majority and the refusal of President 
Bush and Republican members of Congress to yield ground, the efforts of Democrats to extract significant concessions from Republicans were often blocked and frustrated. For example, President Bush, who had vetoed only one bill during his first six years in the White House, rejected seven in $2007 .^{81}$

The partisan acrimony and ideological disputes in the narrowly divided Congress were intensified by the 2008 presidential campaign. Both parties forced votes they knew they could not win, in hopes of making life miserable for their opponents, shaping issues for the election, and polishing their own political images. The year was one of the most partisan in Congress in at least a half-century. Congressional Quarterly's annual study of party unity votes showed that 62 percent of House votes fell into that category, the highest percentage since 1995. Partisan voting was almost as frequent in the Senate as in the House, with the parties split on 60 percent of the votes (2007 CQ Almanac, B-3). According to the analysis, House Democrats on average voted with the party on 92 percent of the party unity votes, while Senate Democrats on average voted with the party on 87 percent of the party unity votes. Republicans stuck together less often on party unity votes, but they did so when it counted. House Republicans were able to obstruct, and occasionally effectively halt, the Democratic agenda, succeeding on a remarkable 21 occasions in ordering bills returned to committee for changes more to their liking. The

\footnotetext{
${ }^{81}$ During the first session of the $110^{\text {th }}$ Congress, a total of 138 public laws were enacted. The number of bills and resolutions introduced was 9,227 in total, 3,033 in the Senate, and 6,194 in the House. The number of roll call votes was 1,628 in total, 442 in the Senate, and 1,186 in the House. President Bush issued 7 vetoes (2007 CQ Almanac, 1-8).
} 
House held a record 1,177 roll call votes during the year, in part as a result of GOP attempts to amend and recommit bills. ${ }^{82}$

But it was in the Senate that Republicans had the greatest clout. Minority Leader Mitch McConnell (R-KY) became adept at using the Senate's procedures to kill or force major revisions to Democratic bills, particularly at using amendments and prolonged debate to force Reid to hold cloture votes, a method of limiting debate that required 60 votes to succeed. With a narrow majority of 51-49, Democrats won just half the 62 cloture votes held during the year. With their narrow majorities, Democrats scored some of their high-profile achievements only after they made significant concessions to Republicans. Senate Republicans skillfully used their ability to block cloture motions to force changes in legislation to their liking. In the House, where the minority was more tightly constrained by the majority's control of the rule process, Republicans made creative use of an arcane procedure to recommit or return bills to committee - essentially requiring that certain changes be made, or in some instances killing the bill (2007 CQ Almanac, 1:6-7). ${ }^{83}$

Nevertheless, with a majority in Congress, Democrats had the opportunity to probe executive branch activities that had been subject to virtually no congressional oversight while Republicans were in control. Democrats undertook the job immediately and enthusiastically. The most dramatic outcome of the committee investigations was the

\footnotetext{
${ }^{82}$ When quorum calls are included, in which members record only whether they are present, the number of roll call votes in the House was 1,186 in 2007.

${ }^{83}$ Under House rules, the minority cannot be denied the right to offer a motion to recommit with instructions on a bill or joint resolution that is on the floor. As the minority in the House for the first time in 12 years, House Republicans exercised considerable procedural prowess. For more details, see the $2008 \mathrm{CQ}$ Almanac, 1-11.
} 
resignation of Attorney General Alberto R. Gonzales in September. Gonzales had lost credibility with members of Congress from both parties due to embarrassing revelations about his involvement in the administration's firing of nine U.S. attorneys and a probe of the National Security Agency's warrantless wiretapping program. The House Oversight and Government Reform Committee looked into corruption in the Iraqi government and waste and fraud in the reconstruction of Iraq, while the House Armed Services Committee probed the readiness of military forces strained by continuing deployments in Iraq. Numerous committees held hearings on the Iraq War and the impact of the troop surge. The first session of the $110^{\text {th }}$ Congress ended, as it had begun, with partisanship in full swing.

In 2008, Democratic members of Congress were less ambitious than the previous year in achieving their legislative agenda ${ }^{84}$ They did not press the president on domestic and foreign issues, with the expectation that the Democratic presidential candidate would win the upcoming 2008 presidential election and the Democratic Party would control the both chambers of Congress. In addition, they had to cooperate with President Bush and the Republic Party to address the worsening economic and financial crisis. However, this did not necessarily mean that partisan wrangling disappeared in the second session of the $110^{\text {th }}$ Congress. Partisanship was as high as it had been in any recent year, reflected in the high percentage of party unity votes. The year 2008 presented "the capstone for an era under Bush that was the most polarized period since Congressional Quarterly began examining partisan voting in 1953" (2008 CQ Almanac, 1-3).

\footnotetext{
${ }^{84}$ During the second session of the $110^{\text {th }}$ Congress, a total of 285 public laws were enacted. The number of bills and resolutions introduced was 4,815 in total, 1,590 in the Senate, and 3,225 in the House. The number of roll call votes was 905 in total, 215 in the Senate, and 690 in the House. The president Bush vetoed 4 times during the session (2008 CQ Almanac, 1-8).
} 
The pre-election partisanship, however, was overshadowed by an increasingly urgent and severe economic recession involving the collapse of the housing market, the possible breakdown of credit market, declining consumer spending, and increasing unemployment. With a national economy on the verge of collapse, the partisan lines between the two parties were blurred. In October, Congress granted the Department of Treasury the bipartisan authority "to use a staggering $\$ 700$ billion in an effort to rescue the financial services industry, after allowing up to $\$ 800$ billion to salvage mortgage finance giants Fannie Mae and Freddie Mac" (2008 CQ Almanac, 1-3).

Because of the economic and financial crisis coupled with the unpopularity of President Bush, Republicans lost both the presidential and congressional elections on the fourth of November. Democrats added to their majorities in both houses of Congress, and Barack Hussein Obama, the Democratic presidential candidate, was elected as the nation's first African-American president. ${ }^{85}$ Many other factors, no doubt, contributed to the election victory of Obama, including his "appeal to the youth vote, his tactical flexibility and highly organized grass-roots campaign, and his obvious command of the issues" (2008 CQ Alamanc, 1-11). Immediately after the election, president-elect Obama began to lay out his ambitious plans for his new administration.

In sum, during this period, President Bush lost the vital political leverage in Congress that was necessary for him to keep pushing his domestic foreign policies. His

\footnotetext{
${ }^{85}$ Although Democrats failed to achieve their long-shot quest for the 60 seats needed to dominate the Senate in the 2008 elections, their net gain of at least seven seats brought their number to 58 , counting the two independents. The Minnesota senatorial race was undecided at the end of the year 2008 (2008 CQ Almanac, 1-11). In 2009, however, as a result both of the victory of Al Franken (D-MN) in Minnesota and of the decision of Senator Arlen Specter (R-PA) to switch his party from the Republican to the Democratic Party, the Democratic Party finally achieved the magic 60 seats needed to stop Republican filibusters in the Senate. In the House, Democrats strengthened their control with a net gain of 21 seats, making it the second consecutive election where the party gained a significant number of House seats (2008 CQ Almanac, 1-11).
} 
confidence and leadership were seriously undermined, and the partisan resistance from the Democratic majority in Congress was greatly intensified. President Bush also had to learn to live with divided government and to change his approach toward North Korea.

\subsubsection{Presidency vs. Congress: North Korea}

In 2007, when the Democratic Party became a majority in both chambers, the dynamics changed. The Bush administration and the defeated Republican Party had no choice but to adjust their North Korea policy. In December 2007, in accordance with the 2007 National Defense Authorization Act, President Bush appointed as North Korea Policy Coordinator Christopher Hill, who was also Assistant Secretary of State for East Asian and Pacific Affairs and Head of the U.S. delegation to the Six-Party Talks on the North Koran nuclear issue. The North Korea Policy Coordinator was expected to review President Bush's North Korea Policy, and submit a report on the investigations. In May 2008, the House passed the Nuclear Proliferation Bill (HR5916) that would allow the president to waive the so-called 1994 Glenn amendment (PL 103-236) to the Arms Export Control Act, which prohibited many U.S. dealings with countries that illegally develop nuclear weapons. The passage of the bill allowed the use of U.S. equipment and funding in dismantling North Korea's nuclear reactor at Yongbyon and disposing of its radioactive material (2008 CQ Almanac, 2-27). The House actions coincided with progress in U.S.-North Korean disarmament negotiations (Graham-Silverman, 2008). The more important is the changed policy toward Pyongyang of the Bush administration. Immediately after the victory of the Democratic Party in the 2006 midterm elections, 
President Bush was forced by the new Democratic majority Congress to change his coercive and confrontational diplomacy to more cooperative policy based on diplomacy and negotiation.

Republican members of Congress, however, continued to be opposed to the changes in Bush's North Korea policy. They forced President Bush to "stay the course," and called on the president to set the parameters within which the Six-Party Talks took place. Even on the eve of the February 2007 session of the Six-Party Talks, for example, Senator Richard Lugar (R-IN) expressed his concern by complaining that officials were creating "countervailing situations" that were undermining US diplomacy (Martin, 2007, 85). Democratic members of Congress, on the other hand, generally welcomed and supported Bush's new North Korea policy.

The removal of North Korea from the list of state sponsors of terrorism in 2008 would have been impossible, had the Republicans controlled Congress. A Republican majority Congress would undoubtedly have voted against the delisting (Kim, 2008). Especially after the defeat in the 2006 mid-term elections, therefore, the Bush administration had no choice but to adjust its North Korea policy. As a result, U.S.-North Korean disarmament negotiations were resumed and a series of negotiations produced a significant development in the denuclearization of North Korea. Without a doubt, Democratic legislators welcomed and supported the Bush administration's new North Korea policy. 


\subsection{Conclusion}

In 2001-2006, President Bush adopted a more aggressive policy toward North Korea under a unified government and took a tougher stance on the North Korea nuclear issue. Bush was able to pursue such an aggressive policy because he could expand his own win-set with strong support from Congress. This ultimately led to Pyongyang's first nuclear test in 2006. In 2007-2008, however, President Bush accepted a more conciliatory policy toward North Korea under a divided government that gave him less room to maneuver.

Congress began to limit Bush's policy to North Korea after the 2006 midterm elections, and the divided government considerably undermined President Bush's predominance in his dealings with North Korea. The democratic majority in Congress compelled him to agree with "the Initial Actions for the Implementation" and "the Second-Phase Actions for the Implementation," to remove North Korea from the list of state sponsors of terrorism, and to lift some economic sanctions imposed under the Trading with the Enemy Act. President Bush had to give up the "CVID" policy and the “dismantle first" policy that were uncompromising North Korea policy principles during his first term of office. Thus, the shift toward divided government with intensified partisanship also led inevitably to a shift in policy toward North Korea-from a more aggressive policy in 2001-2006 to a status quo policy in 2007-2008. 


\section{CONCLUSION}

Most studies of U.S. policy toward North Korea have explained tension in USNorth Korea relations in terms either of Pyongyang's intractable and provocative nature or of Washington's misguided approaches (President Clinton's appeasement policy or President Bush's coercive diplomacy). In other words, many studies have tended to blame leaders (Kim, Clinton, or Bush) for the policy breakdown that led to a nuclear North Korea.

Another possible explanation for the failure of the Agreed Framework and Pyongyang's nuclearization is that the rise of neoconservative ideology during the Bush administration led to provocative U.S. policies toward Pyongyang that made these outcomes inevitable (Feffer, 2003; Armstrong, 2006; Pritchard, 2007; Chinoy, 2008). In general, it is true that the rise of the neoconservative movement in the U.S. was associated with a deterioration of U.S.-D.P.R.K. relations, and its decline in the latter years of the Bush administration helped to defuse some of the tension.

Yet, neither successes nor failures have been limited to single administration or party in the United States. Moreover, the neoconservative movement itself should be understood within the broader context of domestic politics, and interbranch competition, within the United States. North Korea's responses must also be considered, although neither Pyongyang's intransigence nor a general predilection for strategic extortion can explain the roller coaster ride of the past two decades.

The structural realist (neorealist) perspective may also provide some insights, particularly insofar as it stresses Pyongyang's vulnerabilities and bargaining objectives. 
Precisely because the structural realist perspective dominates the field of International Relations, domestic sources of foreign policy have typically been disregarded or ignored. As a result, studies emphasizing the significance of domestic variables in US policy making have not been systematically developed or tested. Although the international factor is certainly a necessary condition for the explanation of US foreign policy, it is not a sufficient condition. It must be complemented by the explanations that consider domestic factors.

Domestic politics in the U.S. are, in fact, central to any convincing explanation of the advances and retreats in the U.S. relationship with North Korea. Executive-legislative relations in the United States take on a different character in periods of unified government than in periods of divided government. And since the U.S. Constitution distributes power over foreign policy between the executive and legislative branches, this internal balance of power turns out to be crucial. Because many important foreign policy matters fall into a zone of negotiation between Congress and the president, "an invitation to struggle" is inevitable. Simply put, the branches are "too evenly matched" (Ware, 2001, $35)$.

Divided government makes this problem more problematic. According to Ware (2001):

If we exclude the exceptional case of Ford, and the Reagan experience of having to deal with only one chamber controlled by the opposition, we are left facing the conclusion that divided government tends to produce confrontation, unless the president has limited public policy objectives. The experience of Truman (1947- 
8), Nixon (1969-74), Reagan (1987-8), Bush (1989-92), and Clinton (from 1995)

suggests that there is an inherent tension between the separation of powers and party power when government is divided... Divided government in the post-New Deal era has added significantly to the difficulty of governing a country that was already difficult to govern — partly because of its size and diversity, and partly because of the dispersion of political power created by the Constitution (Ware, $2001,35-6){ }^{86}$

Under circumstances of divided party control of government, furthermore, ideological differences and partisan politics easily escalate into institutional warfare between the president and the Congress. Divided government converts intrinsic partisan tension into more overt conflict. ${ }^{87}$ During the Clinton and Bush administrations, in fact, the routinization of partisanship, the politicization of foreign policy, and the intensification of interbranch rivalry became "the rule rather than the exception" (Mann, 1990, 2-3). In other words, politics did not stop at the water's edge. As a consequence, different government types significantly affected the United States' North Korea policy during the Clinton and Bush administrations.

As the framers of U.S. Constitution apparently intended, divided government has served, in the case of U.S. policy toward North Korea, to slow down or hold back activist policy. The result has mostly been the status quo. On the other hand, a unified government lets a president take up a more active foreign policy. Moreover, parties also

\footnotetext{
${ }^{86}$ However, "divided government may well persist... since the prospects for that kind of reform are slim, the problems associated with divided government will surely persist well into this century" (Ware, 2001, 39).

${ }^{87}$ Usually ideological differences are more conducive to partisanship. Sometimes, however, even "an enormous amount of partisan conflict in Congress occurs on issues that are not identifiably ideological" (Lee, 2009, 19).
} 
clearly had an impact, which was not intended by the framers. When it comes to U.S. North Korea policy, divided governments produced more status quo policies and fewer upheavals in U.S.-North Korea relations. Unified governments, on the other hand, produced more radical changes, and the direction of the changes depended on the party in power.

Table 8 summarizes the relations between U.S. government types and U.S. North Korea policy.

Table 8. U.S. Government Types and U.S. North Korea Policy

\begin{tabular}{|c||c|c|}
\hline President & Unified Government & Divided Government \\
\hline Democratic & $\begin{array}{c}\text { Conciliatory Engagement } \\
\text { (Geneva Agreement, 1994) }\end{array}$ & $\begin{array}{c}\text { Status Quo/Passive Engagement } \\
\text { (Cancelled Summit, 2000) }\end{array}$ \\
\hline Republican & $\begin{array}{c}\text { Confrontational Engagement } \\
\text { (North Korea Nuclear Test, 2006) }\end{array}$ & $\begin{array}{c}\text { Status Quo/Passive Engagement } \\
\text { (Gradual Rapprochement, 2007) }\end{array}$ \\
\hline
\end{tabular}

A unified U.S. government with a Democratic President produced a more conciliatory policy toward North Korea, while a unified U.S. government with a Republican President produced a more aggressive policy. In both cases, however, the unified government allowed a form of presidential activism. President Clinton embraced 
an active policy (conciliatory engagement) under Democratic unified government (19931994), while President Bush adopted an active policy in the opposite direction (confrontational engagement) under Republican unified government (2001-2006).

The findings in this dissertation extend those of other studies on the role of different U.S. government types in U.S. foreign policy. Typically, these studies argue that divided governments have played pivotal roles, and that different government types produce different policy choices and approaches. These studies also argue that partisan politics plays a crucial role. In this sense, North Korea is a hard case: if any policy is likely to attract bipartisan support, preventing North Korea from obtaining nuclear weapons is surely such a policy.

At the same time, the findings in this dissertation challenge those of earlier studies on the role of Congress in U.S. foreign policy, which argue that presidential power has significantly grown over the past century, whereas congressional power has considerably declined (Wildavsky, 1966; Schlesinger, 1973; Hinckley, 1994; Peterson, 1994a; Weissman, 1995; Ohaegbulam, 2007; Hansen \& Friedman, 2009). The findings also dispute the notion that Congress is "all talk," and that members of Congress are much more interested in paying lip service to their audience than in producing substantial policies. As in U.S. domestic policy (Mycoff \& Pika, 2008), Congress has clearly played an important role in U.S. foreign policy, sometimes complementing presidential actions, and at other times complicating those efforts. When it comes to U.S. foreign policy toward North Korea, Congress never provided a rubber stamp for administration initiatives. 
Many questions, however, remain to be explored. One is whether Republicans adopt more aggressive foreign policies and Democrats more conciliatory foreign policies in general. It is clear that the Republican President and party were more confrontational in their North Korea policy, while the Democratic President and party were more conciliatory during the Clinton and Bush administrations. It is sometimes assumed that Republican foreign policy is generally more aggressive because it is based on the notion of national defense through self-reliance, while Democratic foreign policy is more conciliatory because it places more emphasis on international cooperation.

The Democratic Party, however, has been as aggressive as the Republican Party in other circumstances. Woodrow Wilson was active, ambitious, and aggressive in his dealings with Central Powers, including Germany, Austria-Hungary, the Ottoman Empire, and Bulgaria, during and after WWI. During his term of office, President Harry S. Truman also took an aggressive stance against the expansion of Communism. It was also Truman, of course, who authorized use of atomic bombs against Japan to end WWII, and who dispatched U.S. troops to Korea. Presidents John F. Kennedy and Lyndon B. Johnson expanded and escalated the Vietnam War. President Clinton, despite his conciliatory policy toward North Korea, took a very tough stance on international human rights violations. He authorized aircraft strikes against Bosnian Serbs in 1995 and the use of U.S. troops in a NATO bombing campaign against Yugoslavia in 1999.

Conversely, the Republican Party was often as conciliatory as the Democratic Party. Republicans historically disapproved of interventionist foreign policy. They opposed President Woodrow Wilson's intervention in WWI and his enthusiastic effort to create the League of Nations. They were also opposed to intervention in WWII before 
Pearl Harbor. In the 1970s, President Richard Nixon, through his historic visit to the People's Republic of China, opened a new era of U.S.-China relations, which subsequently paved the way for détente. In the 1980s, even President Ronald Reagan adopted more conciliatory foreign policies during his second term. In the 1990s, Republicans opposed U.S. intervention in Somalia and in the Balkans. In sum, it would be hard to sustain the claim that Democrats are conciliatory and Republicans are aggressive. The question thus remains: why were Republicans more confrontational, and Democrats less so, in U.S. North Korea policy during the Clinton and Bush administrations?

A related question is whether the same pattern will exist in U.S. policy toward other so-called rogue states. Countries like Iran and Cuba have also been described as members of "Axis of Evil" or "State Sponsors of Terrorism." " Comparative studies of such cases would put the findings of this dissertation in a broader context. One might also ask whether the pattern identified here will persist in the Obama administration's policy toward North Korea. Like his two predecessors, President Obama took his office with a unified government. So far, however, his policy toward North Korea is not notable for engagement of either type: conciliatory or coercive.

For a complete study of bilateral relations between the United States and North Korea in the 1990s and 2000s, furthermore, it will be essential to examine North Korea's policy toward the United States in the same period. This dissertation has generally assumed that North Korea was consistent in its policy toward the United States during the

\footnotetext{
${ }^{88}$ Currently there are four countries designated as state sponsors of terrorism: Cuba, Iran, Sudan and Syria (Department of State, 2010).
} 
period. Although Pyongyang might have been consistent in its policy goals and strategies, however, it adopted different tactics and reactions to different U.S. policy approaches. Exploring the dyadic and dynamic interactions between the United States and North Korea will tell another important side of the story.

To understand Pyongyang's foreign policy behavior, as with the United States, the major domestic determinants of North Korea's policy making toward the United States should be considered. Although North Korea is an authoritarian state and the leader's power is paramount, its foreign policy nevertheless has a domestic context. Due to its authoritarian nature and military-first policy, relations between the executive branch and the military (instead of relations between the executive and legislative branches) - and, more specifically, relations between Ministry of Foreign Affairs and the National Defense Commission - are central to this part of the story.

Finally, one should not forget the role of other East Asian states, including South Korea, Japan, Russia, and China, in U.S.-North Korea relations. In particular, foreign policies of the participants in the Six-Party Talks are of great consequence. However, the Six-Party Talks are another story in themselves. 


\section{REFERENCES}

Alesina, A., \& Rosenthal, H. (1995). Partisan Politics, Divided Government, and the Economy. Cambridge: Cambridge University Press.

Allison, G. (2007, February 13). Entering the Reality Zone on North Korea. The National Interest Online.

Armstrong, C. K. (2006). US-North Korean relations. In J. Feffer (Ed.), The Future of US-Korean Relations: The Imbalance of Power (chapter 1). New York: Routledge.

Auerswald, D., \& Maltzman, F. (2003). Policymaking through Advice and Consent:

Treaty Considerations by the United States Senate. The Journal of Politics, 65(4), 1097-1110.

Bader, J. B. (1997). The Contract with America: Origins and Assessments. In L. C. Dodd, $\&$ B. I. Oppenheimer (Eds), Congress Reconsidered (chapter $15,6^{\text {th }}$ ed.). Washington, D.C.: CQ Press.

Barilleaux, R. J., \& Kim, A. I. (1999). Clinton, Korea, and Presidential Diplomacy. World Affairs, 162(1). Retrieved from http://find.galegroup.com.ezproxy.fiu.edu/itx/start.do?prodId=AIM

Barilleaux, R. J., \& Zellers, D. (2009). How George W. Bush Remade American Foreign Policy. In M. J. Rozell, \& G. Whitney (Eds), Testing The Limits: George W. Bush and the Imperial Presidency (chapter 4). Lanham, MD: Rowman \& Littlefield.

Berkowitz, M., Bock, P. G., \& Fuccillo, V. J. (1977). The Politics of American Foreign Policy: The Social Context of Decisions. Englewood Cliffs, NJ: Prentice-Hall.

Binder, S. A. (1999). The Dynamics of Legislative Gridlock, 1947-96. American Political Science Review, 93(3), 519-533.

Binder, S. A. (2001). Congress, the Executive, and the Production of Public Policy: United We Govern? In L. C. Dodd, \& B. I. Oppenheimer (Eds), Congress Reconsidered (chapter $13,7^{\text {th }}$ ed.). Washington, D.C.: CQ Press.

Bond, J. R., \& Fleisher, R. (1990). The President in the Legislative Arena. Chicago: The University of Chicago Press.

Brooks, S. G., \& Wohlforth, W. C. (2002). American Primacy in Perspective. Foreign Affairs, 81(4). Retrieved from http://www.foreignaffairs.com/articles/58034/stephen-g-brooks-andwilliam-c-wohlforth/american-primacy-in-perspective 
Bruckman, D. (1978). Boundary Role Conflict: Negotiation as Dual Responsiveness. In W. I. Zartman (Ed.), The Negotiation Process: Theories and Applications (chapter 5). Beverly Hills, CA: Sage Publications.

Brzezinski, Z. (1984). The Three Requirements for a Bipartisan Foreign Policy. In The Washington Quarterly White Paper (chapter 2). Washington, D.C.: Center for Strategic and International Studies, Georgetown University.

Bueno de Mesquita, B., Smith A., Siverson, R. M., \& Morrow, J. D. (2003). The Logic of Political Survival. Cambridge, MA: The MIT Press.

Bulychev, G. (2007, February 15). North Korea: Nuclear Menace or Paper Tiger? Japan Focus.

Bunn, G., \&Chyba, C. F. (2006). U.S. Nuclear Weapons Policies for a New Year. In G. Bunn, \& C. F. Chyba (Eds.), U.S. Nuclear Weapons Policy: Confronting Today's Threats (chapter 8). Baltimore: Brookings Institution Press.

Burgin, E. (1997). Assessing Congress's Role in the Making of Foreign Policy. In L. C. Dodd, \& B. I. Oppenheimer (Eds.), Congress Reconsidered (chapter 13, $6^{\text {th }}$ ed.). Washington, D.C.: CQ Press.

Bush, G. W. (2001, November 6). You are either with us or against us. CNN.

Campbell, C. C., Rae, N. C., \& Stack, J. F. Jr. (2003). Congress and the Politics of Foreign Policy. Upper Saddle River, NJ: Prentice Hall.

Carpenter, T. G., \& Bandow, D. (2004). The Korean Conundrum: America's Troubled Relations with North and South Korea. New York: Palgrave.

Carter, R, \& Scott, J. (2010). Institutional Actors in Foreign Policy Analysis. In R. A. Denemark (Ed.), The International Studies Encyclopedia. Blackwell Publishing. Retrieved from http://www.isacompendium.com/subscriber/tocnode? $\mathrm{id}=\mathrm{g} 978144336697 \mathrm{ch}$ unk_g97814433659711_ss1-8

Carter, R. G. (1998). Congress and Post-Cold War U.S. Foreign Policy. In J. M. Scott (Ed.), After the End: Making U.S. Foreign Policy in the Post-Cold War World (chapter 5). Durham: Duke University Press.

Carter, R., \& Scott, J. (2004). Taking the Lead: Congressional Foreign Policy Entrepreneurs and U.S. Foreign Policy. Politics and Policy, 32(1), 34-70. 
Carter, R., \& Scott, J. (2009). Choosing to Lead: Understanding Congressional Foreign Policy Entrepreneurs. Durham, NC: Duke University Press.

Cha. V. D., \& Kang, D.C. (2003). Nuclear North Korea: A Debate on Engagement Strategies. New York: Columbia University Press.

Cheney, D. (1990). Congressional Overreaching in Foreign Policy. In R. A. Goldwin, \& R. A. Licht (Eds.), Foreign Policy and the Constitution (chapter 7). Washington, D.C.: American Enterprise Institute.

Cheong, W. (2006, June 26). North Korea Stands to Lose with Missile Launch. Policy Forum Online. The Nautilus Institution.

Cheong, W. (2009, August 26). The Way to Denuclearize North Korea. Policy Forum Online. The Nautilus Institution.

Chinoy, M. (2008). Meltdown: The Inside Story of the North Korean Nuclear Crisis. New York: St. Martin's Press.

Christopher, W. (1983). Ceasefire between the Branches: A Compact in Foreign Affairs. Foreign Affairs, 61(5), 989-1005.

Chun, C. (2009, June 11). Moving From a North Korean Nuclear Problem to the Problem of North Korea. Policy Forum Online. The Nautilus Institution.

Congressional Quarterly, inc. (1993-2008). Congressional Quarterly Almanac (Volumes, 49-64). Washington, D.C.: Congressional Quarterly Press.

Conley, R. S. (2003). The Presidency, Congress, and Divided Government: A Postwar Assessment. College Station: Texas A\&M University Press.

Cooper, J. (2009). From Congressional to Presidential Preeminence: Power and Politics in Late Nineteenth-Century America and Today. In L.C. Dodd, \& B. I. Oppenheimer (Eds.), Congress Reconsidered (chapter 16, $9^{\text {th }}$ ed.). Washington, D.C.: CQ Press.

Cooper, J., \& Young, G. (1997). Partisanship, Bipartisanship, and Crosspartisanship in Congress since the New Deal. In L. C. Dodd, \& B. I. Oppenheimer (Eds.), Congress Reconsidered (chapter 11, $6^{\text {th }}$ ed.). Washington, D.C.: CQ Press.

Corwin, E. S. (1957). The President: Office and Powers, 1787-1957. New York: New York University Press.

Cossa, R. (2003, September 2). North Korea: Digging Deeper Holes. PacNet, 37. 
Cotton, J. (2006, September 13). Missiles and Sanctions: Has a Watershed Been Reached in The Korean Nuclear Crisis? Policy Forum Online. The Nautilus Institution.

Cowie, N. (2006, May 4). US Financial Allegations - What They Mean. Policy Forum Online. The Nautilus Institution.

Cox, C. (2000). House Republican Policy Committee Perspective on US aid to North Korea. July 27.

Cox, G. W., \& Kernell, S. (Eds.). (1991). The Politics of Divided Government. Boulder, CO: Westview Press.

Crabb, C. V., \& Holt, P. M. (1989). Invitation to Struggle: Congress, the President, and Foreign Policy $\left(5^{\text {th }}\right.$ ed.). Washington, D.C.: CQ Press.

Crovitz, L. G., \& Rabkin, J. A. (Eds.) (1989). The Fettered Presidency: Legal Constraints on the Executive Branch. Washington, D.C.: American Enterprise Institute.

Cumings, B., Abrahamian, E., \& Ma'oz, M. (2004). Inventing the Axis of Evil. New York and London: The New Press.

Cutler, L. N. (1980). To Form a Government. Foreign Affairs, 59(1), 126-143.

Dahl, R. A. (1950). Congress and Foreign Policy. New York: Norton.

Delaet, C. J., \& Scott, J. M. (2006). Treaty-making and Partisan Politics: Arms Control and the U.S. Senate, 1960-2001. Foreign Policy Analysis, 2(2), 177-200.

Delaet, C. J., Rowling, C., \& Scott, J. M. (2005). Politics Past the Edge: Partisanship and Arms Control Treaties in the U.S. Senate. Journal of Political and Military Sociology, 33(2), 179-208.

Department of Defense. (2001). Nuclear Posture Review [Excerpts], submitted to Congress. December 31.

Department of State. (2005). Regional Topics.

Department of State. (2008). North Korea: Presidential Action on State Sponsor of Terrorism (SST) and the Trading with the Enemy Act (TWEA).

Department of State. (2010). State Sponsors of Terrorism. 
Destler, I. M. (2001). Congress and Foreign Policy at Century's End: Requiem on Cooperation? In L. C. Dodd, \& B. I. Oppenheimer (Eds.), Congress Reconsidered (chapter $14,7^{\text {th }}$ ed.). Washington, D.C.: CQ Press.

Destler, I. M., Gelb, L. H., \& Lake, A. (1984). Our Own Worst Enemy: The Unmaking of American Foreign Policy. New York: Simon and Schuster.

Edwards, G. C., III, Barrett, A., \& Peake, J. (1997). The Legislative Impact of Divided Government. American Journal of Political Science, 41(2), 545-563.

Elgie, R. (Ed.). (2001). Divided Government in Comparative Perspective. Oxford: Oxford University Press.

Feffer, J. (2003). North Korea South Korea: U.S. Policy at a Time of Crisis. New York: Seven Stories Press.

Feffer, J. (2006, July 3). North Korean Fireworks? Policy Forum Online. The Nautilus Institution.

Fiorina, M. P. (1996a). Divided Government (2 ${ }^{\text {nd }}$ ed.). Boston: Allyn and Bacon.

Fiorina, M. P. (1996b). The Causes and Consequences of Divided Government: Lessons of 1992-1994. In P. F. Galderisi with R. Q. Herzberg, \& P. McNamara (Eds.), Divided Government: Change, Uncertainty, and the Constitutional Order (chapter 2). Lanham, MD: Rowman \& Littlefield.

Fisher, L. (2007). Constitutional Conflicts between Congress and the President $\left(5^{\text {th }}\right.$ ed., revised). Lawrence: University Press of Kansas.

Fisher, L. (2008). Costly Presidential Wars. In E. R. Wittkopf, \& J. M. McCormick (Eds.), The Domestic Sources of American Foreign Policy: Insights \& Evidence (Introduction, $5^{\text {th }}$ ed.). Lanham, MD: Rowman \& Littlefield.

Fleisher, R., Bond, J. R., Krutz, G. S., \& Hanna, S. (2000). The Demise of the Two Presidencies. American Politics Quarterly, 28(1), 3-25.

Fordham, B. O. (2002). Another Look at "Parties, Voters, and the Use of Force Abroad." The Journal of Conflict Resolution, 46(4), 572-596.

Franck, T. M., \& Weisband, E. (1979). Foreign Policy by Congress. Oxford: Oxford University Press.

Freedman, L. (2003). The Evolution of Nuclear Strategy, third edition. New York: Palgrave Macmillan. 
Goldstein, J. (2009). How Light Water Reactors Figure Into Negotiations with North Korea. Bulletin of the Atomic Scientists, 65(4), 64-71.

Gowa, J. (1998). Politics at the Water's Edge: Parties, Voters, and the Use of Force Abroad. International Organization, 52(2), 307-324.

Graham-Silverman, A. (2008). Bill Would Reward North Korea for Nuclear Disarmament Efforts. CQ Weekly Online. May 19.

Hamilton, L. (2006). The Making of U.S. Foreign Policy: The Roles of the President and Congress over Four Decades. In J. A. Thurber (Ed.), Rivals for Power: Presidential-Congressional Relations (chapter 11). Lanham: Rowman \& Littlefield.

Hansen, V. M., \& Friedman, L. (2009). The Case for Congress: Separation of Powers and the War on Terror. Burlington, VT: Ashgate.

Harrison, S. S. (2002). Korean Endgame: A Strategy for Reunification and U.S. Disengagement. Princeton: Princeton University Press.

Hathaway, R. M., \& Tama, J. (2004). The U.S. Congress and North Korea during the Clinton Years: Talk Tough, Carry a Small Stick. Asian Survey, 44( 5), 711-733.

Hauben, R. (2007, June 5). Behind the Blacklisting of Banco Delta Asia. Policy Forum Online. The Nautilus Insititution.

Hayes, P. (2006a, July 7). Stop Hyperventilating, Start Talking. Policy Forum Online. The Nautilus Institution.

Hayes, P. (2006b, July 21). Embrace Tiger, Retreat To Mountain, Test Nuke. Policy Forum Online. The Nautilus Institution.

Hayes, P. (2007, February 14). The Beijing Deal is not the Agreed Framework. Policy Forum Online. The Nautilus Institution.

Henkin, L. (1996). Foreign Affairs and the US Constitution. Oxford: Clarendon Press.

Hermann, M. G., Preston, T., Korany, B., \& Shaw, T. M. (2001). Who Leads Matters: The Effects of Powerful Individuals. International Studies Review, 3(2), 83-131.

Hersman, R. K. C. (2000). Friends and Foes: How Congress and the President Really Make Foreign Policy. Washington, D.C.: Brookings Institution Press.

Hinckley, B. (1994). Less Than Meets the Eye: Congress, the President, and Foreign Policy. Chicago: University of Chicago Press. 
Holsti, O. R., \& Rosenau, J. N. (1984). American Leadership in World Affairs. Boston: Allen \& Unwin.

Howell, W. G., \& Pevehouse, J. C. (2005). Presidents, Congress, and the Use of Force. International Organization, 59(1), 209-232.

Howell, W. G., \& Pevehouse, J. C. (2007). When Congress Stops Wars. Foreign Affairs, 86(5). Retrieved from http://www.foreignaffairs.com/articles/62831/william-ghowell-and-jon-c-pevehouse/when-congress-stops-wars

Hwang, J. (2004). Realism and U.S. Foreign Policy toward North Korea: The Clinton and Bush Administration in Comparative Perspective. World Affairs, 167(1), 15-29.

Ikenberry, G. J. (Ed.). (2002). American Unrivaled: The Future of the Balance of Power. Ithaca: Cornell University Press.

Jones, C. O. (2005). The Presidency in a Separated System ( $2^{\text {nd }}$ ed.). Washington, DC: Brookings Institution.

Jones, G. S., \& Marini, J. (Eds.). (1988). The Imperial Congress: Crisis in the Separation of Powers. New York: Pharos Books.

Kaplan, F. (2004, May). Rolling Blunder: How the Bush Administration Let North Korea Get Nukes. Washington Monthly.

Kapstein, E. B., \& Mastanduno, M. (Eds.). (1999). Unipolar Politics: Realism and State Strategies after the Cold War. New York: Columbia University Press.

Kelley, D. R. (Ed.). (2005). Divided Power: The Presidency, Congress, and the Formation of American Foreign Policy. Fayetteville: University of Arkansas Press.

Kelly, S. O. (1993). Divided We Govern? A Reassessment. Polity, 25(3), 475-484.

Kernell, S. (1991). Facing an Opposition Congress: The Presidents Strategic Circumstance. In G. W. Cox, \& S. Kernell (Eds.), The Politics of Divided Government (chapter 5). Boulder, CO: Westview Press.

Kessler, G. (2005, May 1). North Korea Labels Bush a 'Dictator'. The Washington Post.

Kessler, G. (2007, February 15). Conservatives Assail North Korea Accord: Deal Could Get Nation off Terrorism List. The Washington Post. 
Kim, K. (2007, May 24). Lessons from the BDA Issue. Policy Forum Online. The Nautilus Institution.

Kim, T. (2006, August 1). Strange Tempests Follow Missile Tests. Policy Forum Online. The Nautilus Institution.

Kim, T. (2007, April 3). BDA: Hill's Tactical Miscalculation. Policy Forum Online. The Nautilus Institution.

Kim, T. (2008, June 24). North Korean Denuclearization: Beyond Phase II Disablement. Policy Forum Online. The Nautilus Institution.

Kim, T. (2009a, March 17). North Korea Watches Washington. Policy Forum Online. The Nautilus Institution.

Kim, T. (2009b, August 11). The Significance of Clinton's Visit to North Korea. Policy Forum Online. The Nautilus Institution.

Kim, T. (2010, May 3). Requisites for North Korea's Denuclearization. Policy Forum Online. The Nautilus Institution.

Koh, B. C. (2006, August 30). North Korea's Missile Launches and Six-Party Talks. Policy Forum Online. The Nautilus Institution.

Koh, H. H. (1988). Why the President (Almost) Always Wins in Foreign Affairs: Lessons of the Iran-Contra Affair. The Yale Law Journal, 97(7), 1255-1342.

Koh, H. H. (1990). The National Security Constitution: Sharing Power after the IranContra Affair. New Haven: Yale University Press.

Krehbiel, K. (1998). Pivotal Politics. Chicago: University of Chicago Press.

Layman, G. C., Carsey, T. M., Green, J. C., Herrera, R., \& Cooperman, R. (2010). Activists and Conflict Extension in American Party Politics. American Political Science Review, 104(2), 324-346.

Leach, J. (2005, May 31). Speech at the Conference "Prospects for U.S. Policy toward the Korean Peninsula in the Second Bush Administration." Policy Forum Online. The Nautilus Institution.

Lee, C. (2006). A Troubled Peace: U.S. Policy and the Two Koreas. Baltimore: Johns Hopkins University Press.

Lee, F. E. (2009). Beyond Ideology: Politics, Principles, and Partisanship in the U.S. Senate. Chicago: The University of Chicago Press. 
Lee, K., \& Miles, A. (2006). North Korea on Capitol Hill. In J. Feffer (Ed.), The Future of US-Korean Relations: The Imbalance of Power (chapter 8). New York: Routledge.

Leffler, M. P., \& Legro, J. W. (2008). To Lead the World: American Strategy after the Bush Doctrine. Oxford: Oxford University Press.

LeLoup, L. T., \& Shull, S. A. (2003). The President and Congress: Collaboration and Combat in National Policymaking ( $2^{\text {nd }}$ ed.). New York: Longman.

Lim, W. (2006, July 7). North Korea's Missile Tests: Malign Neglect Meets Brinkmanship. Policy Forum Online. The Nautilus Institution.

Lindsay, J. M. (1992/3). Congress and Foreign Policy: Why the Hill Matters. Political Science Quarterly, 107(4), 607-628.

Lindsay, J. M. (1994). Congress and the Politics of U.S. Foreign Policy. Baltimore: The Johns Hopkins University Press.

Lindsay, J. M. (2007). The Shifting Pendulum of Power: Executive-Legislative Relations on American Foreign Policy. In E. R. Wittkopf, \& J. M. McCormick (Eds.), The Domestic Sources of American Foreign Policy: Insights \& Evidence (chapter 12, $5^{\text {th }}$ ed.). Lanham, MD: Rowman \& Littlefield.

Lindsay, J. M., \& Ripley, R. B. (1992). Foreign and Defense Policy in Congress: A Research Agenda for the 1990s. Legislative Studies Quarterly, 17, 417-449.

Litwak, R. S. (2000). Rogue States and U.S. Foreign Policy: Containment after the Cold War. Washington, D.C.: The Woodrow Wilson Center Press.

Lohmann, S., \& O’Halloran, S. (1994). Divided Government and U.S. Trade Policy: Theory and Evidence. International Organization, 48(4), 595-632.

Mann, T. E. (Ed.). (1990). A Question of Balance: The President, the Congress, and Foreign Policy. Washington, D.C.: The Brookings Institution.

Manning, B. (1977). The Congress, the Executive and Intermestic Affairs: Three Proposals. Foreign Affairs, 55(2). Retrieved from http://www.heinonline.org.ezproxy.fiu.edu/HOL/Page?handle=hein.journals /fora55\&id $=1 \&$ size $=2 \&$ collection $=$ journals\&index $=$ journals/fora

Martin, C. H. (2007). U.S. Policy Toward North Korea Under George, W. Bush: A Critical Appraisal. In S. Joo, \& T. Kwak (Eds.), North Korea's Second Nuclear Crisis and Northeast Asian Security (chapter 4). Burlington, VT: Ashgate. 
Martin, L. L. (2000). Democratic Commitments: Legislatures and International Cooperation. Princeton: Princeton University Press.

Mathis, N. (1994, June 13). U.S.-N. Korea Must Comply before Aid Is Considered. The Houston Chronicle.

Mayhew, D. (2005). Divided We Govern: Party Control, Lawmaking, and Investigations, 1946-1990 ( $2^{\text {nd }}$ ed.). New Haven: The Yale University Press.

Mazarr, M. J. (1995). North Korea and the Bomb: A Case Study in Nonproliferation. London: Macmillan.

McCormack, G. (2007, February 14). A Denuclearization Deal in Beijing: The Prospect of Ending the $20^{\text {th }}$ Century in East Asia. Japan Focus.

McCormick, J. E., \& Wittkopf, E. R. (1990). Bipartisanship, Partisanship, and Ideology in Congressional-Executive Foreign Policy Relations, 1947-1988. Journal of Politics, 52(4), 1077-1100.

McCormick, J. E., Wittkopf, E. R., \& Danna, D. M. (1997). Politics and Bipartisanship at the Water's Edge: A Note on Bush and Clinton. Polity, 30(1), 133-149.

Meernik, J. (1993). Presidential Support in Congress: Conflict and Consensus on Foreign and Defense Policy. The Journal of Politics, 55(3), 569-587.

Meernik, J. (1995). Congress, the President, and the Commitment of the U.S. Military. Legislative Studies Quarterly, 20(3), 377-293.

Melanson, R. (1996). American Foreign Policy since the Vietnam War: The Search for Consensus from Nixon to Clinton. Armonk, NY: M. E. Sharpe.

Menefee-Libey, D. (1991). Divided Government as Scapegoat. PS: Political Science \& Politics, 24(4), 643-646.

Mezey, M. L. (1989). Congress, the President, \& Public Policy. Boulder, CO: Westview Press.

Miles, A. (2005, February 28). The U.S. Congress and North Korea Policy: What's Next for the $109^{\text {th }}$ Congress? Policy Forum Online. The Nautilus Institution.

Moravcsik, A. (1999). Integrating International and Domestic Theories of International Bargaining. In P. B. Evans, H. K. Jacobson, \& R. D. Putnam (Eds.), International Bargaining and Domestic Politics: Double-Edged Diplomacy (Introduction). Berkeley: University of California Press. 
Morgan, P. M. (2007). The Role of the United States in the North Korean Nuclear Crisis. In T. Roehrig, J. Seo, \& U. Heo (Eds.), Korean Security in a Changing East Asia (chapter 2). Westport, CT: Praeger Security International.

Morgenthau, H. J. (1993). Politics among Nations: The Struggles for Power and Peace (brief ed.). Boston: McGraw-Hill.

Mycoff, J. D., \& Pika, J. A. (2008). Confrontation \& Compromise: Presidential and Congressional Leadership, 2001-2006. Lanham, MD: Rowman \& Littlefield.

Nelson, M. (2008). Person and Office: Presidents, the Presidency, and Foreign Policy. In E. R. Wittkopf, \& J. M. McCormick (Eds.), The Domestic Sources of American Foreign Policy: Insights \& Evidence (chapter 9, $5^{\text {th }}$ ed.). Lanham, MD: Rowman \& Littlefield.

Neustadt, R. E. (1990). Presidential Power and the Modern Presidents: The Politics of Leadership from Roosevelt to Reagan. New York: Free Press.

Nogee, J. L. (1981). Congress and Presidency: The Dilemmas of Policy-Making in a Democracy. In J. Spanier, \& J. Nogee (Eds.), Congress, The Presidency and American Foreign Policy (chapter 8). New York: Pergamon Press.

North Korea Advisory Group. (1999). Report to the Speaker U.S. House of Representatives.

Nye, J. S., Jr. (1995). East Asian Security: The Case for Deep Engagement. Foreign Affairs, 74(4). Retrieved from http://www.foreignaffairs.com/articles/51210/joseph-s-nye-jr/east-asiansecurity-the-case-for-deep-engagement

Nye, J. S., Jr. (2002). The Paradox of American Power: Why the World's Only Superpower Can't Go It Alone. Oxford: Oxford University Press.

O'Halloran, S. (1994). Politics, Process, and American Trade Policy. Ann Arbor: The University of Michigan Press.

Ohaegbulam, F. U. (2007). A Culture of Deference: Congress, The President, and the Course of the U.S.-led Invasion and Occupation of Iraq. New York: Peter Lang.

Oldfield, D. M., \& Wildavsky, A. (1991). Reconsidering the Two Presidencies. In S. A. Shull (Ed.), The Two Presidencies: A Quarter Century Assessment (chapter 13). Chicago: Nelson-Hall Publishers. 
Olsen, E. A. (2007). The Bush Administration and North Korea's Nuclear Policy. In S. Joo, \& T. Kwak (Eds.), North Korea's Second Nuclear Crisis and Northeast Asian Security (chapter 3). Burlington, VT: Ashgate.

Ornstein, N., \& Mann, T. (2006). When Congress Checks Out. Foreign Affairs, 85(6), 67-82.

Park. H. S. (2002). North Korea: The Politics of Unconventional Wisdom. Boulder: Lynne Rienner Publishers.

Peterson, P. E. (Ed.). (1994a). The President, the Congress, and the Making of Foreign Policy. Norman: University of Oklahoma Press.

Peterson, P. E. (1994b). The International System and Foreign Policy. In P. E. Peterson (Ed.), The President, the Congress, and the Making of Foreign Policy (chapter 1). Norman: University of Oklahoma Press.

Peterson, P. E. (1994c) The President's Dominance in Foreign Policy Making. Political Science Quarterly, 109(2), 215-234.

Pfiffner, J. P. (2006). Partisan Polarization, Politics, and the Presidency: Structural Sources of Conflict. In J. A. Thurber (Ed.), Rivals for Power: PresidentialCongressional Relations (chapter 2, $3^{\text {rd }}$ ed.). Lanham, MD: Rowman \& Littlefield.

Pinkston, D. (2006, June 8). Will North Korea Launch a Long-range Missile? Policy Forum Online. The Nautilus Institution.

Pinkston, D. (2008). The North Korean Ballistic Missile Program. Carlisle, PA: Strategic Studies Institute.

Pritchard, C. L. (2007). Failed Diplomacy: The Tragic Story of How North Korea Got the Bomb. Washington, D.C.: Brookings Institution Press.

Putnam, R. (1988). Diplomacy and domestic politics: the logic of two-level games. International Organization, 42(3), 427-460.

Quinones, C. K. (2007a). Korean Peninsula Energy Development Organization (KEDO) A Bridge Too Far? In S. Joo, \& T. Kwak (Eds.), North Korea's Second Nuclear Crisis and Northeast Asian Security (chapter 9). Burlington, VT: Ashgate.

Quinones, C. K. (2007b, February 20). Can the New Nuclear Deal with North Korea Succeed? Policy Forum Online. The Nautilus Institution.

Rice, C. (2005). Opening Statement by Dr. Condoleezza Rice Before the Senate Foreign Relations Committee. January 18. 
Ripley, R. B. \& Lindsay, J. M. (Eds.). (1993). Congress Resurgent: Foreign and Defense Policy on Capitol Hill. Ann Arbor: University of Michigan Press.

Rohde, D. (1994). Partisan, Leadership, and Congressional Assertiveness in Foreign and Defense Policy. In D. A. Deese (Ed.), The New Politics of American Foreign Policy (chapter 4). New York: St. Martin's.

Rosati, J. A. \& Scott, J. M. (2007). The Politics of United States Foreign Policy (4 ${ }^{\text {th }}$ ed.). Belmont, CA: Thomson Higher Education.

Rosati, J., \& Twing, S. (1998). The Presidency and U.S. Foreign Policy after the Cold War. In J. M. Scott (Ed.), After the End: Making U.S. Foreign Policy in the PostCold War World (chapter 2). Durham: Duke University Press.

Rosenau, J. N. (2008). People Count! Networked Individuals in Global Politics. Boulder, CO: Paradigm Publishers.

Rosner, J. D. (1995). The New Tug-of-War: Congress, the Executive Branch, and National Security. Washington, D.C.: Carnegie Endowment for International Peace.

Rozell, M. J. \& Whitney, G. (Eds.). (2009). Testing the Limits: George W. Bush and the Imperial Presidency. Lanham, MD: Rowman \& Littlefield.

Schier, S. E. (2009). Panorama of a Presidency: How George W. Bush Acquired and Spent His Political Capital. Armonk, NY: M.E. Sharpe.

Schifferes, S. (2003, June 18). U.S. Splits Deepen over North Korea. BBC News World Edition.

Schlesinger, A. M., Jr. (1973). The Imperial Presidency. Boston: Houghton Mifflin Company.

Schmitt, C. (2007). The Concept of the Political (Expanded ed.). Chicago: The University of Chicago Press.

Scott, J. M. (1997). In the Loop. Journal of Political and Military Sociology, 25(1), 47-75.

Scott, J. M., \& Carter, R. G. (2002). Acting on the Hill: Congressional Assertiveness in U.S. Foreign Policy. Congress and the Presidency, 29(2), 151-170.

Scott, J. M., \& Crothers, A. L. (1998). Out of the Cold: The Post-Cold War Context of U.S. Foreign Policy. In J. M. Scott (Ed.), After the End: Making U.S. Foreign Policy in the Post-Cold War World (chapter 1). Durham: Duke University Press. 
Sigal, L. V. (1998). Disarming Strangers: Nuclear Diplomacy with North Korea. Princeton: Princeton University Press.

Sigal, L. V. (2006, July 27). What North Korea’s Missile Test Means. Policy Forum Online. The Nautilus Institution.

Silbey, J. H. (1996). Divided Government in Historical Perspective, 1789-1996. In P. F. Galderisi, R. Q. Herzberg, \& P. McNamara (Eds.), Divided Government: Change, Uncertainty, and the Constitutional Order (chapter 1). Lanham: Rowman \& Littlefield.

Simpson, J. (1994). Nuclear Non-proliferation in the Post-Cold War Era. International Affairs, 70(1), 17-39.

Sinclair, B. (1993). Congressional Party Leaders in the Foreign and Defense Policy Arena. In R. B. Ripley, \& J. M. Lindsay (Eds.), Congress Resurgent: Foreign and Defense Policy on Capitol Hill (chapter 9). An Arbor: University of Michigan Press.

Sinclair, B. (1997). Party Leaders and the New Legislative Process. In L. C. Dodd, \& B. I. Oppenheimer (Eds.), Congress Reconsidered (chapter 10, $6^{\text {th }}$ ed.). Washington, D.C.: CQ Press.

Smith, A. (1998). International Crises and Domestic Politics. The American Political Science Review, 92(3), 623-638.

Smith, S. S. (1994). Congressional Party Leaders. In P. E. Peterson (Ed.), The President, the Congress, and the Making of Foreign Policy (chapter 6). Norman: University of Oklahoma Press.

Spanier, J. \& Nogee, J. (Eds.). (1981). Congress, The Presidency and American Foreign Policy. New York: Pergamon Press.

Stockman, F. (2005, May 9). Nations say US shirks its arms vows: The spotlight shifts at nuclear conference. The Boston Globe.

Sundiquist, J. (1981). The Decline and Rise of Congress. Washington, D.C.: The Brookings Institution.

Sundquist, J. L. (1980). The Crisis of Competence in Our National Government. Political Science Quarterly, 95(2), 183-208.

Sundquist, J. L. (1988/9). Needed: A Political Theory for the New Era of Coalition Government in the United States. Political Science Quarterly, 103(4), 613-635. 
Szamuely, G. (1987, September). The Imperial Congress. Commentary.

The Library of Congress. (2004). http://thomas.loc.gov/cgibin/bdquery/D?d108:2:./temp/ bdKUoK:@@@@\&summ2=m\&//home/Legislativ eData.php?n=BSS;c=108

The New York Times. (2004). The 9/11 Report: The National Commission on Terrorist Attacks Upon the United States. New York: St. Martin's Press.

The White House. (2001). Address to a Joint Session of Congress and the American People. September 20.

The White House. (2002a). The National Security Strategy of the United States of America.

The White House. (2002b). The President's State of the Union Address. January 29.

The White House. (2003). President George Bush Discusses Iraq in National Press Conference. March 6.

The White House. (2005). Press Conference of the President. April 28.

The World Bank. (2009, July 1). World Development Indicators Database

Theriault, S. M. (2008). Party Polarization in Congress. Cambridge: Cambridge University Press.

Thurber, J. A. (Ed.). (1991). Divided Democracy: Cooperation and Conflict between the President and Congress. Washington, D.C.: Congressional Quarterly Press.

Thurber, J. A. (Ed.). (2006). Rivals for Power: Presidential-Congressional Relations $\left(3^{\text {rd }}\right.$ ed.). Lanham, MD: Rowman \& Littlefield.

Tower, J. G. (1981/2). Congress versus the President: The Formulation and Implementation of American Foreign Policy. Foreign Affairs, 60(2), 229-246.

Walker, W. (2000). Nuclear Order and Disorder. International Affairs, 76(4), 703-724.

Walt, S. M. (2000). Two Cheers for Clinton's Foreign Policy. Foreign Affairs, 79(2). Retrieved from http://www.foreignaffairs.com/articles/55848/stephen-mwalt/two-cheers-for-clintons-foreign-policy

Warburg, G. F. (1989). Conflict and Consensus: The Struggle between Congress and the President over Foreign Policymaking. New York: Harper and Row. 
Ware, A. (2001). Divided Government in the United States. In R. Elgie (Ed.). Divided Government in Comparative Perspective (chapter 2). Oxford: Oxford University Press.

Weissman, S. R. (1995). A Culture of Deference: Congress's Failure of Leadership in Foreign Policy. New York: BasicBooks.

Wildavsky, A. (1966). The Two Presidencies. Trans-Action, 4, 7-14. Reprinted in S. A. Shull (Ed.). The Two Presidencies: A Quarter Century Assessment (chapter 2, 1991). Chicago: Nelson-Hall Publishers.

Wit, J. S., Poneman, D. B., \& Gallucci, R. L. (2004). Going Critical: The First North Korean Nuclear Crisis. Washington, D.C.: Brookings Institution Press.

Wittkopf, E. R., \& McCormick, J. M. (1998). Congress, the President, and the End of the Cold War: Has Anything Changed? Journal of Conflict Resolution, 42(4), 440466.

Wittkopf, E. R., \& McCormick, J. M. (Eds.). (2008). The Domestic Sources of American Foreign Policy: Insights \& Evidence ( $5^{\text {th }}$ ed.). Lanham, MD: Rowman \& Littlefield.

Wittkopf, E. R., Kegley, C. W., \& Scott, J. M. (2003). American Foreign Policy: Pattern and Process $\left(6^{\text {th }}\right.$ ed.). Stamford: Thomas Wadsworth.

Wolfensberger, D. R. (2002). The Return of the Imperial Presidency? Wilson Quarterly, 26(2), 36-41.

Woodward, B. (2002). Bush at War. New York: Simon \& Schuster. 


\section{APPENDICES}

1. 1994 Geneva Agreed Framework between USA and DPRK

(http://www.armscontrol.org/documents/af).....

2. 2000 US-DPRK Joint Communique

(

http://www.state.gov/www/regions/eap/001012_usdprk_jointcom.html

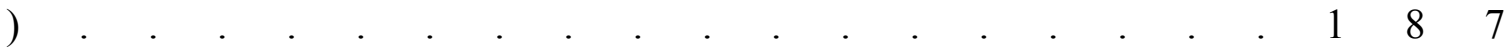

3. 2004 U.S. North Korean Human Rights Act: An Excerpt

(http://www.northkoreanrefugees.com/hr4011.pdf).

4. 2005 Joint Statement of the Fourth Round of the Six-Party Talks

(http://www.fmprc.gov.cn/eng/zxxx/t212707.htm ).

5. 2007 Initial Actions for the Implementation of the Joint Statement (http://www.fmprc.gov.cn/eng/zxxx/t297463.htm)....

6. 2007 Second-Phase Actions for the Implementation of the Joint Statement (http://www.mfa.gov.cn/eng/zxxx/t369084.htm). 


\title{
AGREED FRAMEWORK BETWEEN THE UNITED STATES OF AMERICA AND THE DEMOCRATIC PEOPLE'S REPUBLIC OF KOREA
}

\author{
Geneva, October 21, 1994
}

Delegations of the governments of the United States of America (U.S.) and the Democratic People's Republic of Korea (DPRK) held talks in Geneva from September 23 to October 21, 1994, to negotiate an overall resolution of the nuclear issue on the Korean Peninsula.

Both sides reaffirmed the importance of attaining the objectives contained in the August 12, 1994 Agreed Statement between the U.S. and the DPRK and upholding the principles of the June 11, 1993 Joint Statement of the U.S. and the DPRK to achieve peace and security on a nuclear-free Korean peninsula. The U.S. and the DPRK decided to take the following actions for the resolution of the nuclear issue:

\section{Both sides will cooperate to replace the DPRK's graphite-moderated reactors and related facilities with light-water reactor $(\mathrm{LWR})$ power plants.}

1) In accordance with the October 20, 1994 letter of assurance from the U.S. President, the U.S. will undertake to make arrangements for the provision to the DPRK of a LWR project with a total generating capacity of approximately $2,000 \mathrm{MW}(\mathrm{e})$ by a target date of 2003.

- The U.S. will organize under its leadership an international consortium to finance and supply the LWR project to be provided to the DPRK. The U.S., representing the international consortium, will serve as the principal point of contact with the DPRK for the LWR project.

- The U.S., representing the consortium, will make best efforts to secure the conclusion of a supply contract with the DPRK within six months of the date of this Document for the provision of the LWR project. Contract talks will begin as soon as possible after the date of this Document.

- As necessary, the U.S. and the DPRK will conclude a bilateral agreement for cooperation in the field of peaceful uses of nuclear energy.

2) In accordance with the October 20, 1994 letter of assurance from the U.S. President, the U.S., representing the consortium, will make arrangements to offset the energy foregone due to the freeze of the DPRK's graphite-moderated reactors and related facilities, pending completion of the first LWR unit.

- Alternative energy will be provided in the form of heavy oil for heating and electricity production. 
- Deliveries of heavy oil will begin within three months of the date of this Document and will reach a rate of 500,000 tons annually, in accordance with an agreed schedule of deliveries.

3) Upon receipt of U.S. assurances for the provision of LWR's and for arrangements for interim energy alternatives, the DPRK will freeze its graphite-moderated reactors and related facilities and will eventually dismantle these reactors and related facilities.

- The freeze on the DPRK's graphite-moderated reactors and related facilities will be fully implemented within one month of the date of this Document. During this one-month period, and throughout the freeze, the International Atomic Energy Agency (IAEA) will be allowed to monitor this freeze, and the DPRK will provide full cooperation to the IAEA for this purpose.

- Dismantlement of the DPRK's graphite-moderated reactors and related facilities will be completed when the LWR project is completed.

- The U.S. and the DPRK will cooperate in finding a method to store safely the spent fuel from the $5 \mathrm{MW}(\mathrm{e})$ experimental reactor during the construction of the LWR project, and to dispose of the fuel in a safe manner that does not involve reprocessing in the DPRK.

4) As soon as possible after the date of this document U.S. and DPRK experts will hold two sets of experts talks.

- At one set of talks, experts will discuss issues related to alternative energy and the replacement of the graphite-moderated reactor program with the LWR project.

- At the other set of talks, experts will discuss specific arrangements for spent fuel storage and ultimate disposition.

\section{The two sides will move toward full normalization of political and economic relations.}

1) Within three months of the date of this Document, both sides will reduce barriers to trade and investment, including restrictions on telecommunications services and financial transactions.

2) Each side will open a liaison office in the other's capital following resolution of consular and other technical issues through expert level discussions.

3) As progress is made on issues of concern to each side, the U.S. and the DPRK will upgrade bilateral relations to the Ambassadorial level. 


\section{Both sides will work together for peace and security on a nuclear-free Korean peninsula.}

1) The U.S. will provide formal assurances to the DPRK, against the threat or use of nuclear weapons by the U.S.

2) The DPRK will consistently take steps to implement the North-South Joint Declaration on the Denuclearization of the Korean Peninsula.

3) The DPRK will engage in North-South dialogue, as this Agreed Framework will help create an atmosphere that promotes such dialogue.

\section{Both sides will work together to strengthen the international nuclear non proliferation regime.}

1) The DPRK will remain a party to the Treaty on the Non-Proliferation of Nuclear Weapons (NPT) and will allow implementation of its safeguards agreement under the Treaty.

2) Upon conclusion of the supply contract for the provision of the LWR project, ad hoc and routine inspections will resume under the DPRK's safeguards agreement with the IAEA with respect to the facilities not subject to the freeze. Pending conclusion of the supply contract, inspections required by the IAEA for the continuity of safeguards will continue at the facilities not subject to the freeze.

3) When a significant portion of the LWR project is completed, but before delivery of key nuclear components, the DPRK will come into full compliance with its safeguards agreement with the IAEA (INFCIRC/403), including taking all steps that may be deemed necessary by the IAEA, following consultations with the Agency with regard to verifying the accuracy and completeness of the DPRK's initial report on all nuclear material in the DPRK.

Robert L. Gallucci

Head of Delegation of the United States of America, Ambassador at Large of the United States of America
Kang Sok Ju

Head of the Delegation of the

Democratic People's Republic of Korea, First Vice-Minister of Foreign Affairs of the Democratic People's Republic of Korea 


\section{US - DPRK JOINT COMMUNIQUE}

\section{U.S. Department of State, October 12, 2000}

As the special envoy of Chairman Kim Jong Il of the D.P.R.K. National Defense Commission, the First Vice Chairman, Vice Marshal Jo Myong Rok, visited the United States of America from October 9-12, 2000.

During his visit, Special Envoy Jo Myong Rok delivered a letter from National Defense Commission Chairman Kim Jong Il, as well as his views on U.S.-D.P.R.K. relations, directly to U.S. President William Clinton. Special Envoy Jo Myong Rok and his party also met with senior officials of the U.S. Administration, including his host Secretary of State Madeleine Albright and Secretary of Defense William Cohen, for an extensive exchange of views on issues of common concern. They reviewed in depth the new opportunities that have opened up for improving the full range of relations between the United States of America and the Democratic People's Republic of Korea. The meetings proceeded in a serious, constructive, and businesslike atmosphere, allowing each side to gain a better understanding of the other's concerns.

Recognizing the changed circumstances on the Korean Peninsula created by the historic inter-Korean summit, the United States and the Democratic People's Republic of Korea have decided to take steps to fundamentally improve their bilateral relations in the interests of enhancing peace and security in the Asia-Pacific region. In this regard, the two sides agreed there are a variety of available means, including Four Party talks, to reduce tension on the Korean Peninsula and formally end the Korean War by replacing the 1953 Armistice Agreement with permanent peace arrangements.

Recognizing that improving ties is a natural goal in relations among states and that better relations would benefit both nations in the 21 st century while helping ensure peace and security on the Korean Peninsula and in the Asia-Pacific region, the U.S. and the D.P.R.K. sides stated that they are prepared to undertake a new direction in their relations. As a crucial first step, the two sides stated that neither government would have hostile intent toward the other and confirmed the commitment of both governments to make every effort in the future to build a new relationship free from past enmity.

Building on the principles laid out in the June 11, 1993 U.S.-D.P.R.K. Joint Statement and reaffirmed in the October 21, 1994 Agreed Framework, the two sides agreed to work to remove mistrust, build mutual confidence, and maintain an atmosphere in which they can deal constructively with issues of central concern. In this regard, the two sides reaffirmed that their relations should be based on the principles of respect for each other's sovereignty and noninterference in each other's internal affairs, and noted the value of regular diplomatic contacts, bilaterally and in broader fora.

The two sides agreed to work together to develop mutually beneficial economic cooperation and exchanges. To explore the possibilities for trade and commerce that will 
benefit the peoples of both countries and contribute to an environment conducive to greater economic cooperation throughout Northeast Asia, the two sides discussed an exchange of visits by economic and trade experts at an early date.

The two sides agreed that resolution of the missile issue would make an essential contribution to a fundamentally improved relationship between them and to peace and security in the Asia-Pacific region. To further the efforts to build new relations, the D.P.R.K. informed the U.S. that it will not launch long-range missiles of any kind while talks on the missile issue continue.

Pledging to redouble their commitment and their efforts to fulfill their respective obligations in their entirety under the Agreed Framework, the US and the D.P.R.K. strongly affirmed its importance to achieving peace and security on a nuclear weapons free Korean Peninsula. To this end, the two sides agreed on the desirability of greater transparency in carrying out their respective obligations under the Agreed Framework. In this regard, they noted the value of the access which removed U.S. concerns about the underground site at Kumchang-ri.

The two sides noted that in recent years they have begun to work cooperatively in areas of common humanitarian concern. The D.P.R.K. side expressed appreciation for significant U.S. contributions to its humanitarian needs in areas of food and medical assistance. The U.S. side expressed appreciation for D.P.R.K. cooperation in recovering the remains of U.S. servicemen still missing from the Korean War, and both sides agreed to work for rapid progress for the fullest possible accounting. The two sides will continue to meet to discuss these and other humanitarian issues.

As set forth in their Joint Statement of October 6, 2000, the two sides agreed to support and encourage international efforts against terrorism.

Special Envoy Jo Myong Rok explained to the US side developments in the inter-Korean dialogue in recent months, including the results of the historic North-South summit. The U.S. side expressed its firm commitment to assist in all appropriate ways the continued progress and success of ongoing North-South dialogue and initiatives for reconciliation and greater cooperation, including increased security dialogue.

Special Envoy Jo Myong Rok expressed his appreciation to President Clinton and the American people for their warm hospitality during the visit.

It was agreed that Secretary of State Madeleine Albright will visit the D.P.R.K. in the near future to convey the views of U.S. President William Clinton directly to Chairman Kim Jong Il of the D.P.R.K. National Defense Commission and to prepare for a possible visit by the President of the United States. 


\section{NORTH KOREAN HUMAN RIGHTS ACT OF 2004: AN EXCERPT}

\section{A BILL}

To promote human rights and freedom in the Democratic People's Republic of Korea, and for other purposes.

Be it enacted by the Senate and House of Representatives of the United States of America in Congress assembled,

\section{SECTION 1. SHORT TITLE.}

This Act may be cited as the 'North Korean Human Rights Act of 2004'.

\section{SEC. 3. FINDINGS.}

Congress makes the following findings:

(1) According to the Department of State, the Government of North Korea is 'a dictatorship under the absolute rule of Kim Jong Il' that continues to commit numerous, serious human rights abuses.

(2) The Government of North Korea attempts to control all information, artistic expression, academic works, and media activity inside North Korea and strictly curtails freedom of speech and access to foreign broadcasts.

(3) The Government of North Korea subjects all its citizens to systematic, intensive political and ideological indoctrination in support of the cult of personality glorifying Kim Jong Il and the late Kim Il Sung that approaches the level of a state religion.

(4) The Government of North Korea divides its population into categories, based on perceived loyalty to the leadership, which determines access to employment, higher education, place of residence, medical facilities, and other resources.

(5) According to the Department of State, '[t]he [North Korean] Penal Code is [d] raconian, stipulating capital punishment and confiscation of assets for a wide variety of 'crimes against the revolution,' including defection, attempted defection, slander of the policies of the Party or State, listening to foreign broadcasts, writing 'reactionary' letters, and possessing reactionary printed matter'.

(6) The Government of North Korea executes political prisoners, opponents of the regime, some repatriated defectors, some members of underground churches, and others, sometimes at public meetings attended by workers, students, and schoolchildren.

(7) The Government of North Korea holds an estimated 200,000 political prisoners in camps that its State Security Agency manages through the use 
of forced labor, beatings, torture, and executions, and in which many prisoners also die from disease, starvation, and exposure.

(8) According to eyewitness testimony provided to the United States Congress by North Korean camp survivors, camp inmates have been used as sources of slave labor for the production of export goods, as targets for martial arts practice, and as experimental victims in the testing of chemical and biological poisons.

(9) According to credible reports, including eyewitness testimony provided to the United States Congress, North Korean Government officials prohibit live births in prison camps, and forced abortion and the killing of newborn babies are standard prison practices.

(10) According to the Department of State, '[g]enuine religious freedom does not exist in North Korea' and, according to the United States Commission on International Religious Freedom, '[t]he North Korean state severely represses public and private religious activities' with penalties that reportedly include arrest, imprisonment, torture, and sometimes execution.

(11) More than 2,000,000 North Koreans are estimated to have died of starvation since the early 1990s because of the failure of the centralized agricultural and public distribution systems operated by the Government of North Korea.

(12) According to a 2002 United Nations-European Union survey, nearly one out of every ten children in North Korea suffers from acute malnutrition and four out of every ten children in North Korea are chronically malnourished.

(13) Since 1995, the United States has provided more than 2,000,000 tons of humanitarian food assistance to the people of North Korea, primarily through the World Food Program.

(14) Although United States food assistance has undoubtedly saved many North Korean lives and there have been minor improvements in transparency relating to the distribution of such assistance in North Korea, the Government of North Korea continues to deny the World Food Program forms of access necessary to properly monitor the delivery of food aid, including the ability to conduct random site visits, the use of native Korean-speaking employees, and travel access throughout North Korea.

(15) The risk of starvation, the threat of persecution, and the lack of freedom and opportunity in North Korea have caused many thousands, perhaps even hundreds of thousands, of North Koreans to flee their homeland, primarily into China.

(16) North Korean women and girls, particularly those who have fled into China, are at risk of being kidnapped, trafficked, and sexually exploited inside China, where many are sold as brides or concubines, or forced to work as prostitutes. 
(17) The Governments of China and North Korea have been conducting aggressive campaigns to locate North Koreans who are in China without permission and to forcibly return them to North Korea, where they routinely face torture and imprisonment, and sometimes execution. (18) Despite China's obligations as a party to the 1951 United Nations Convention Relating to the Status of Refugees and the 1967 Protocol Relating to the Status of Refugees China routinely classifies North Koreans seeking asylum in China as mere 'economic migrants' and returns them to North Korea without regard to the serious threat of persecution they face upon their return.

(19) The Government of China does not provide North Koreans whose asylum requests are rejected a right to have the rejection reviewed prior to deportation despite the recommendations of the 1951 United Nations Convention Relating to the Status of Refugees and the 1967 Protocol Relating to the Status of Refugees that such a right be granted. (20) North Koreans who seek asylum while in China are routinely imprisoned and tortured, and in some cases killed, after they are returned to North Korea.

(21) The Government of China has detained, convicted, and imprisoned foreign aid workers attempting to assist North Korean refugees, including the Reverend Choi Bong Il and Mr. Kim Hee Tae, in proceedings that did not comply with Chinese law or international standards.

(22) In January 2000, North Korean agents inside China allegedly abducted the Reverend Kim Dong-shik, a United States permanent resident and advocate for North Korean refugees, whose condition and whereabouts remain unknown.

(23) Between 1994 and 2003, South Korea has admitted approximately 3,800 North Korean refugees for domestic resettlement, a number small in comparison with the total number of North Korean escapees, but far greater than the number legally admitted by any other country.

(24) Although the principal responsibility for North Korean refugee resettlement naturally falls to the Government of South Korea, the United States should play a leadership role in focusing international attention on the plight of these refugees, formulating international solutions to that profound humanitarian dilemma, and making prudent arrangements to accept a credible number of refugees for domestic resettlement.

(25) In addition to infringing the rights of its own citizens, the Government of North Korea has been responsible in years past for the abduction of numerous citizens of South Korea and Japan, whose condition and whereabouts remain unknown.

\section{SEC. 4. PURPOSES.}

The purposes of this Act are-- 
(1) to promote respect for and protection of fundamental human rights in North Korea;

(2) to promote a more durable humanitarian solution to the plight of North Korean refugees;

(3) to promote increased monitoring, access, and transparency in the provision of humanitarian assistance inside North Korea;

(4) to promote the free flow of information into and out of North Korea; and

(4) to promote progress toward the peaceful reunification of the Korean peninsula under a democratic system of government.

\section{TITLE I--PROMOTING THE HUMAN RIGHTS OF NORTH KOREANS}

SEC. 101. SENSE OF CONGRESS REGARDING NEGOTIATIONS WITH NORTH KOREA.

SEC. 102. SUPPORT FOR HUMAN RIGHTS AND DEMOCRACY PROGRAMS.

SEC. 103. RADIO BROADCASTING TO NORTH KOREA.

SEC. 104. ACTIONS TO PROMOTE FREEDOM OF INFORMATION.

SEC. 105. UNITED NATIONS COMMISSION ON HUMAN RIGHTS.

TITLE II--ASSISTING NORTH KOREANS IN NEED

SEC. 201. REPORT ON UNITED STATES HUMANITARIAN ASSISTANCE.

SEC. 202. ASSISTANCE PROVIDED INSIDE NORTH KOREA.

SEC. 203. ASSISTANCE PROVIDED OUTSIDE OF NORTH KOREA. TITLE III--PROTECTING NORTH KOREAN REFUGEES

SEC. 301. UNITED STATES POLICY TOWARD REFUGEES AND DEFECTORS.

SEC. 302. ELIGIBILITY FOR REFUGEE OR ASYLUM CONSIDERATION.

SEC. 303. REFUGEE STATUS.

SEC. 304. PURSUIT OF FIRST ASYLUM POLICY.

SEC. 305. UNITED NATIONS HIGH COMMISSIONER FOR REFUGEES. 
SEC. 306. HUMANITARIAN PAROLE.

SEC. 307. NORTH KOREAN STATUS ADJUSTMENT.

SEC. 308. TEMPORARY PROTECTED STATUS.

SEC. 309. RIGHT TO ACCEPT EMPLOYMENT.

SEC. 310. ANNUAL REPORTS.

END 


\section{JOINT STATEMENT OF THE FOURTH ROUND OF THE SIX-PARTY TALKS}

\section{Beijing, September 19, 2005}

The Fourth Round of the Six-Party Talks was held in Beijing, China among the People's Republic of China, the Democratic People's Republic of Korea, Japan, the Republic of Korea, the Russian Federation, and the United States of America from July 26th to August 7th, and from September 13th to 19th, 2005.

Mr. Wu Dawei, Vice Minister of Foreign Affairs of the PRC, Mr. Kim Gye Gwan, Vice Minister of Foreign Affairs of the DPRK; Mr. Kenichiro Sasae, Director-General for Asian and Oceanian Affairs, Ministry of Foreign Affairs of Japan; Mr. Song Min-soon, Deputy Minister of Foreign Affairs and Trade of the ROK; Mr. Alexandr Alekseyev, Deputy Minister of Foreign Affairs of the Russian Federation; and Mr. Christopher Hill, Assistant Secretary of State for East Asian and Pacific Affairs of the United States attended the talks as heads of their respective delegations.

Vice Foreign Minister Wu Dawei chaired the talks.

For the cause of peace and stability on the Korean Peninsula and in Northeast Asia at large, the Six Parties held, in the spirit of mutual respect and equality, serious and practical talks concerning the denuclearization of the Korean Peninsula on the basis of the common understanding of the previous three rounds of talks, and agreed, in this context, to the following:

1. The Six Parties unanimously reaffirmed that the goal of the Six-Party Talks is the verifiable denuclearization of the Korean Peninsula in a peaceful manner.

The DPRK committed to abandoning all nuclear weapons and existing nuclear programs and returning, at an early date, to the Treaty on the Non-Proliferation of Nuclear Weapons and to IAEA safeguards.

The United States affirmed that it has no nuclear weapons on the Korean Peninsula and has no intention to attack or invade the DPRK with nuclear or conventional weapons.

The ROK reaffirmed its commitment not to receive or deploy nuclear weapons in accordance with the 1992 Joint Declaration of the Denuclearization of the Korean Peninsula, while affirming that there exist no nuclear weapons within its territory.

The 1992 Joint Declaration of the Denuclearization of the Korean Peninsula should be observed and implemented.

The DPRK stated that it has the right to peaceful uses of nuclear energy. The other parties expressed their respect and agreed to discuss, at an appropriate time, the subject of the provision of light water reactor to the DPRK. 
2. The Six Parties undertook, in their relations, to abide by the purposes and principles of the Charter of the United Nations and recognized norms of international relations.

The DPRK and the United States undertook to respect each other's sovereignty, exist peacefully together, and take steps to normalize their relations subject to their respective bilateral policies.

The DPRK and Japan undertook to take steps to normalize their relations in accordance with the Pyongyang Declaration, on the basis of the settlement of unfortunate past and the outstanding issues of concern.

3. The Six Parties undertook to promote economic cooperation in the fields of energy, trade and investment, bilaterally and/or multilaterally.

China, Japan, ROK, Russia and the US stated their willingness to provide energy assistance to the DPRK.

The ROK reaffirmed its proposal of July 12th 2005 concerning the provision of 2 million kilowatts of electric power to the DPRK.

4. The Six Parties committed to joint efforts for lasting peace and stability in Northeast Asia.

The directly related parties will negotiate a permanent peace regime on the Korean Peninsula at an appropriate separate forum.

The Six Parties agreed to explore ways and means for promoting security cooperation in Northeast Asia.

5. The Six Parties agreed to take coordinated steps to implement the afore-mentioned consensus in a phased manner in line with the principle of "commitment for commitment, action for action".

6. The Six Parties agreed to hold the Fifth Round of the Six-Party Talks in Beijing in early November 2005 at a date to be determined through consultations. 


\section{JOINT STATEMENT FROM THE THIRD SESSION OF THE FIFTH ROUND OF THE SIX-PARTY TALKS}

- Initial Actions for the Implementation of the Joint Statement

The Third Session of the Fifth Round of the Six-Party Talks was held in Beijing among the People's Republic of China, the Democratic People's Republic of Korea, Japan, the Republic of Korea, the Russian Federation and the United States of America from 8 to 13 February 2007.

Mr. Wu Dawei, Vice Minister of Foreign Affairs of the PRC, Mr. Kim Gye Gwan, Vice Minister of Foreign Affairs of the DPRK; Mr. Kenichiro Sasae, Director-General for Asian and Oceanian Affairs, Ministry of Foreign Affairs of Japan; Mr. Chun Yung-woo, Special Representative for Korean Peninsula Peace and Security Affairs of the ROK Ministry of Foreign Affairs and Trade; Mr. Alexander Losyukov, Deputy Minister of Foreign Affairs of the Russian Federation; and Mr. Christopher Hill, Assistant Secretary for East Asian and Pacific Affairs of the Department of State of the United States attended the talks as heads of their respective delegations.

Vice Foreign Minister Wu Dawei chaired the talks.

I. The Parties held serious and productive discussions on the actions each party will take in the initial phase for the implementation of the Joint Statement of 19 September 2005. The Parties reaffirmed their common goal and will to achieve early denuclearization of the Korean Peninsula in a peaceful manner and reiterated that they would earnestly fulfill their commitments in the Joint Statement. The Parties agreed to take coordinated steps to implement the Joint Statement in a phased manner in line with the principle of "action for action".

II. The Parties agreed to take the following actions in parallel in the initial phase:

1. The DPRK will shut down and seal for the purpose of eventual abandonment the Yongbyon nuclear facility, including the reprocessing facility and invite back IAEA personnel to conduct all necessary monitoring and verifications as agreed between IAEA and the DPRK.

2. The DPRK will discuss with other parties a list of all its nuclear programs as described in the Joint Statement, including plutonium extracted from used fuel rods, that would be abandoned pursuant to the Joint Statement.

3. The DPRK and the US will start bilateral talks aimed at resolving pending bilateral issues and moving toward full diplomatic relations. The US will begin the process of removing the designation of the DPRK as a state-sponsor of terrorism and advance the 
process of terminating the application of the Trading with the Enemy Act with respect to the DPRK.

4. The DPRK and Japan will start bilateral talks aimed at taking steps to normalize their relations in accordance with the Pyongyang Declaration, on the basis of the settlement of unfortunate past and the outstanding issues of concern.

5. Recalling Section 1 and 3 of the Joint Statement of 19 September 2005, the Parties agreed to cooperate in economic, energy and humanitarian assistance to the DPRK. In this regard, the Parties agreed to the provision of emergency energy assistance to the DPRK in the initial phase. The initial shipment of emergency energy assistance equivalent to 50,000 tons of heavy fuel oil (HFO) will commence within next 60 days.

The Parties agreed that the above-mentioned initial actions will be implemented within next 60 days and that they will take coordinated steps toward this goal.

III. The Parties agreed on the establishment of the following Working Groups (WG) in order to carry out the initial actions and for the purpose of full implementation of the Joint Statement:

\section{Denuclearization of the Korean Peninsula}

\section{Normalization of DPRK-US relations}

\section{Normalization of DPRK-Japan relations}

\section{Economy and Energy Cooperation}

\section{Northeast Asia Peace and Security Mechanism}

The WGs will discuss and formulate specific plans for the implementation of the Joint Statement in their respective areas. The WGs shall report to the Six-Party Heads of Delegation Meeting on the progress of their work. In principle, progress in one WG shall not affect progress in other WGs. Plans made by the five WGs will be implemented as a whole in a coordinated manner.

The Parties agreed that all WGs will meet within next 30 days.

IV. During the period of the Initial Actions phase and the next phase - which includes provision by the DPRK of a complete declaration of all nuclear programs and disablement of all existing nuclear facilities, including graphite-moderated reactors and reprocessing plant - economic, energy and humanitarian assistance up to the equivalent of 1 million tons of heavy fuel oil (HFO), including the initial shipment equivalent to 50,000 tons of HFO, will be provided to the DPRK. 
The detailed modalities of the said assistance will be determined through consultations and appropriate assessments in the Working Group on Economic and Energy Cooperation.

V. Once the initial actions are implemented, the Six Parties will promptly hold a ministerial meeting to confirm implementation of the Joint Statement and explore ways and means for promoting security cooperation in Northeast Asia.

VI. The Parties reaffirmed that they will take positive steps to increase mutual trust, and will make joint efforts for lasting peace and stability in Northeast Asia. The directly related parties will negotiate a permanent peace regime on the Korean Peninsula at an appropriate separate forum.

VII. The Parties agreed to hold the Sixth Round of the Six-Party Talks on 19 March 2007 to hear reports of WGs and discuss on actions for the next phase. 


\section{JOINT STATEMENT FROM THE SIX-PARTY TALKS}

- "Second-Phase Actions for the Implementation of the September 2005 Joint Statement"

The Foreign Ministry of the People's Republic of China released the following joint statement on October 3, 2007:

The Second Session of the Sixth Round of the Six-Party Talks was held in Beijing among the People's Republic of China, the Democratic People's Republic of Korea, Japan, the Republic of Korea, the Russian Federation and the United States of America from 27 to 30 September 2007.

Mr. Wu Dawei, Vice Minister of Foreign Affairs of the PRC, Mr. Kim Gye Gwan, Vice Minister of Foreign Affairs of the DPRK, Mr. Kenichiro Sasae, Director-General for Asian and Oceanian Affairs, Ministry of Foreign Affairs of Japan, Mr. Chun Yung-woo, Special Representative for Korean Peninsula Peace and Security Affairs of the ROK Ministry of Foreign Affairs and Trade, Mr. Alexander Losyukov, Deputy Minister of Foreign Affairs of the Russian Federation, and Mr. Christopher Hill, Assistant Secretary for East Asian and Pacific Affairs of the Department of State of the United States, attended the talks as heads of their respective delegations.

Vice Foreign Minister Wu Dawei chaired the talks.

The Parties listened to and endorsed the reports of the five Working Groups, confirmed the implementation of the initial actions provided for in the February 13 agreement, agreed to push forward the Six-Party Talks process in accordance with the consensus reached at the meetings of the Working Groups and reached agreement on second-phase actions for the implementation of the Joint Statement of 19 September 2005, the goal of which is the verifiable denuclearization of the Korean Peninsula in a peaceful manner.

\section{On Denuclearization of the Korean Peninsula}

1. The DPRK agreed to disable all existing nuclear facilities subject to abandonment under the September 2005 Joint Statement and the February 13 agreement.

The disablement of the 5 megawatt Experimental Reactor at Yongbyon, the Reprocessing Plant (Radiochemical Laboratory) at Yongbyon and the Nuclear Fuel Rod Fabrication Facility at Yongbyon will be completed by 31 December 2007. Specific measures recommended by the expert group will be adopted by heads of delegation in line with the principles of being acceptable to all Parties, scientific, safe, verifiable, and consistent with international standards. At the request of the other Parties, the United States will lead disablement activities and provide the initial funding for those activities. As a first step, the US side will lead 
the expert group to the DPRK within the next two weeks to prepare for disablement.

2. The DPRK agreed to provide a complete and correct declaration of all its nuclear programs in accordance with the February 13 agreement by 31 December 2007.

3. The DPRK reaffirmed its commitment not to transfer nuclear materials, technology, or know-how.

\section{On Normalization of Relations between Relevant Countries}

1. The DPRK and the United States remain committed to improving their bilateral relations and moving towards a full diplomatic relationship. The two sides will increase bilateral exchanges and enhance mutual trust. Recalling the commitments to begin the process of removing the designation of the DPRK as a state sponsor of terrorism and advance the process of terminating the application of the Trading with the Enemy Act with respect to the DPRK, the United States will fulfill its commitments to the DPRK in parallel with the DPRK's actions based on consensus reached at the meetings of the Working Group on Normalization of DPRK-U.S. Relations.

2. The DPRK and Japan will make sincere efforts to normalize their relations expeditiously in accordance with the Pyongyang Declaration, on the basis of the settlement of the unfortunate past and the outstanding issues of concern. The DPRK and Japan committed themselves to taking specific actions toward this end through intensive consultations between them.

\section{On Economic and Energy Assistance to the DPRK}

In accordance with the February 13 agreement, economic, energy and humanitarian assistance up to the equivalent of one million tons of HFO (inclusive of the 100,000 tons of HFO already delivered) will be provided to the DPRK. Specific modalities will be finalized through discussion by the Working Group on Economy and Energy Cooperation.

\section{On the Six-Party Ministerial Meeting}

The Parties reiterated that the Six-Party Ministerial Meeting will be held in Beijing at an appropriate time.

The Parties agreed to hold a heads of delegation meeting prior to the Ministerial Meeting to discuss the agenda for the Meeting. 
VITA

\section{TAEHYUNG AHN}

November 9, 1968

1993

1999

2005

2009

$2002-2010$
Born, Mokpo, Republic of Korea

B.A., Western History

Seoul National University

Seoul, Korea

M.A., Western History

Seoul National University

Seoul, Korea

Graduate Certificate, Asian Studies

Florida International University

Miami, Florida

M.A., International Studies

Florida International University

Miami, Florida

Doctoral Candidate in International Relations

Florida International University

Miami, Florida

Teaching Assistant

Florida International University

Miami, Florida

Adjunct Instructor

Florida International University

Miami, Florida

\section{PUBLICATIONS AND PRESENTATIONS}

Ahn, Taehyung, (February, 2000). Patriotism of the British Working Class: The Case of the Boer War. The Journal of Western History, 25 (1): 67-102. (In Korean)

Ahn, Taehyung, (November, 2005). A Self-Fulfilling Prophecy? The Foreign Policy of the Bush Administration and the Second Nuclear Crisis between the US and North Korea. Paper presented at International Studies Association Southern Region 2005 Annual Convention, Miami, Florida. 
Ahn, Taehyung, (March, 2006). Threading a Maze: Change in North Korea's Nuclear Policy since the End of the Cold War. Paper presented at International Studies Association 2006 Annual Convention, San Diego, California.

Ahn, Taehyung, (October, 2006). North Korean Policy toward the United States in the Post-Cold War Period. Paper presented at Southern Symposium on Asian Regional Security: Challenges and Opportunities, Tampa, Florida.

Ahn, Taehyung, (March, 2007). US-North Korean Relations in the Post-Cold War Era: A Constructivist Perspective. Paper presented at International Studies Association 2007 Annual Convention, Chicago, Illinois.

Ahn, Taehyung, (March, 2008). From Confrontation to Cooperation: U.S.-North Korean Relations in the Post-Cold War Era. Paper presented at International Studies Association 2008 Annual Convention, San Francisco, California.

Ahn, Taehyung, (February, 2009). The Determinants of US Policy toward North Korea since the End of the Cold War. Paper presented at International Studies Association 2009 Annual Convention, New York, New York.

Ahn, Taehyung, (February, 2010). Presidency, Congress, and US Policy toward North Korea. Paper presented at International Studies Association 2010 Annual Convention, New Orleans, Louisiana. 